\title{
UTILIZAÇÃO DO COMPUTADOR NO PROCESSO DE ENSINO-APRENDIZAGEM: UMA APLICAÇÃO EM PLANEJAMENTO E CONTROLE DA PRODUÇÃO
}

\author{
João Henrique Lopes Guerra
}

\begin{abstract}
Dissertação apresentada à Escola de Engenharia de São Carlos, da Universidade de São Paulo, como parte dos requisitos para a obtenção do título de Mestre em Engenharia de Produção
\end{abstract}

Orientador: Renato Vairo Belhot 


\section{AGRADECIMENTOS}

Gostaria de expressar os meus mais sinceros agradecimentos:

Aos meus pais, João e Faní, recordistas do Nobel da Paciência, e aos meus irmãos, Daniela e João Paulo.

Ao meu orientador, Renato Vairo Belhot, pela orientação, sabedoria, ajuda, força e amizade. tecnologia.

Ao amigo Luiz Fernando Ferreira, pela ajuda na solução dos pepinos da

Aos amigos Cláudio Guilhermão Tavares, Kleber Francisco Esposto e Nídia Pavan Kuri, por tudo.

EESC-USP.

Aos professores e funcionários da Área de Engenharia de Produção da

Aos funcionários das bibliotecas da EESC, do IFSC e do ICMC.

Aos funcionários do CISC.

Agradecimento especial à Coordenação de Aperfeiçoamento de Pessoal de Nível Superior (CAPES), pela bolsa concedida.

"Pedi e vos dará. Buscai e achareis. Batei e vos será aberto. Porque todo aquele que pede, recebe. Quem busca, acha. A quem bate, abrir-se-á.”

S.Mateus, Cap.7, 7-8 
"Não morda meu dedo, olhe para onde estou apontando" (Seymour Pappert) 


\section{SUMÁRIO}

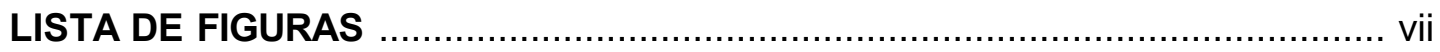

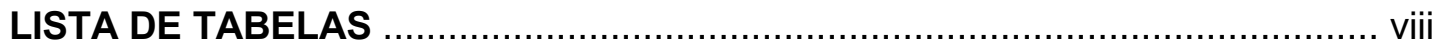

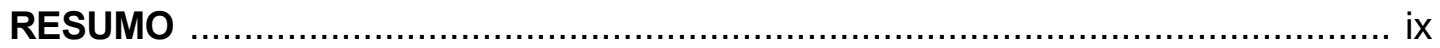

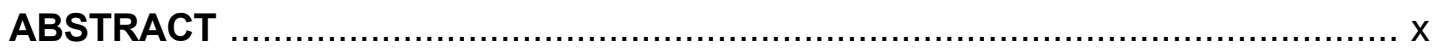

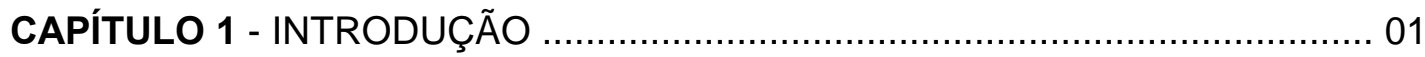

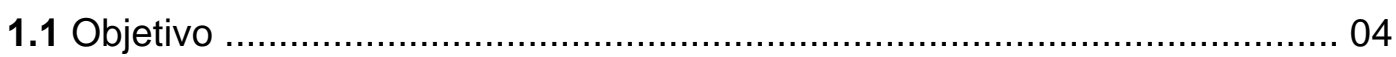

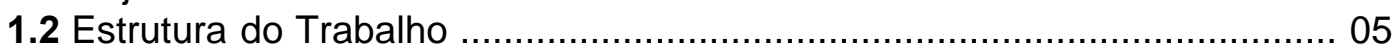

CAPÍTULO 2 - O COMPUTADOR E UM NOVO PARADIGMA PARA A EDUCAÇÃO

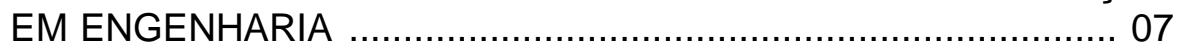

2.1 O Modelo de Ensino Tradicional .......................................................... 11

2.2 Um Novo Paradigma ..................................................................... 13

2.3 O Novo Paradigma e a Tecnologia ……………….................................. 16

$2.4 \mathrm{O}$ Ciclo de Aprendizagem ........................................................................ 18

2.4.1 O Computador no Ciclo de Aprendizagem ……………………..... 21

2.4.2 O Ciclo de Aprendizagem e a Proposta Deste Trabalho ..................... 22

CAPÍTULO 3 - O COMPUTADOR NO PROCESSO DE ENSINO-APRENDIZAGEM:

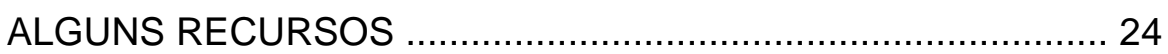

3.1 O Computador e Outras Tecnologias na Educação e no Treinamento ...... 25

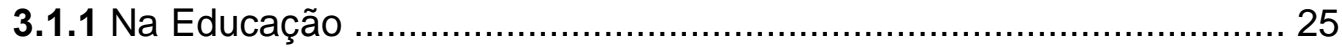

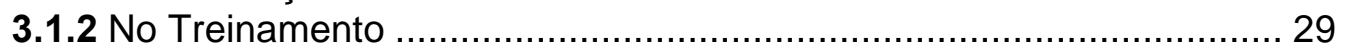

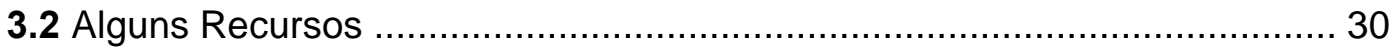

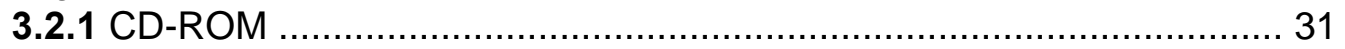

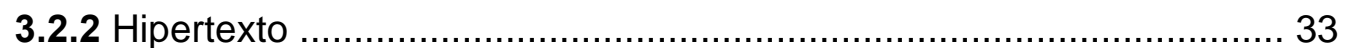

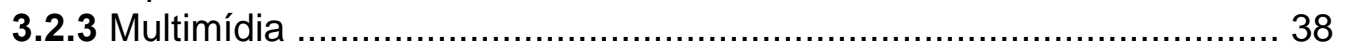

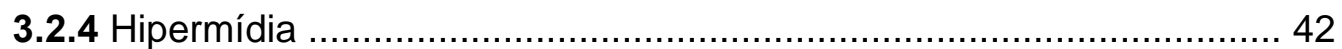

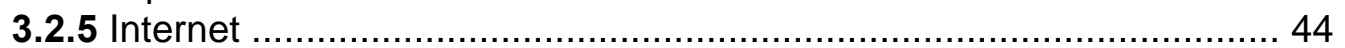

CAPÍTULO 4 - O COMPUTADOR NO PROCESSO DE ENSINO-APRENDIZAGEM: ALGUMAS EXIGÊNCIAS E LIMITAÇÕES ..................................58

4.1 O Computador na Educação: Discutindo Alguns Pontos Críticos ................ 60

4.1.1 O Computador (Tecnologia) ........................................................ 64

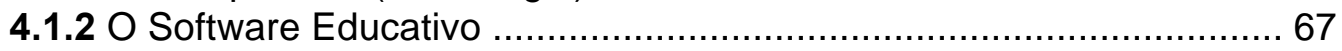

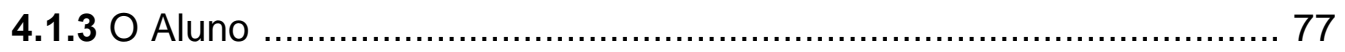

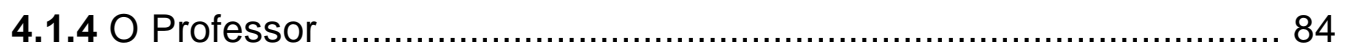


4.2 A Educação a Distância 89

4.2.1 Questões Importantes Relacionadas com a Educação a Distância ... 93

4.2.2 Perspectivas 99

CAPÍTULO 5 - UM AMBIENTE DE APRENDIZAGEM NA WEB 108

5.1 Escolha da Disciplina 108

5.2 Descrição do Ambiente de Aprendizagem Desenvolvido 110

5.2.1 O WebCT 111

5.2.2 O Ambiente de Aprendizagem 118

CAPÍTULO 6 - CONCLUSÃO 133

6.1 Contribuição Deste Trabalho 136

6.2 Proposta para Trabalhos Futuros 139 


\section{LISTA DE FIGURAS}

FIGURA 1 - O ensino tradicional 12

FIGURA 2 - A tecnologia cria um novo caminho até o conhecimento (modificada de BELHOT, 1997a, p.75) .............................................................. 16

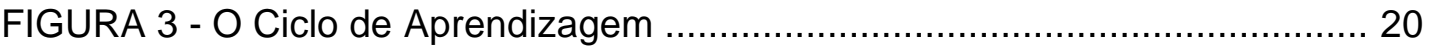

FIGURA 4 - O computador nas fases do Ciclo de Aprendizagem ....................... 22

FIGURA 5 - Uma estrutura simples de hipertexto ................................................. 35

FIGURA 6 - Multimídia: informação em diferentes formatos ............................... 39

FIGURA 7 - A Web: sistema hipermídia ..................................................... 43

FIGURA 8 - As três disciplinas da matéria Planejamento e Controle da Produção e os temas escolhidos da disciplina SEM-387 ................................. 110

FIGURA 9 - Página inicial do WebCT ..................................................... 113

FIGURA 10 - Página do WebCT com links para as listas de cursos .................. 113

FIGURA 11 - Link para o ambiente desenvolvido neste trabalho .................... 114

FIGURA 12 - A mesma página na visão dos alunos e do desenvolvedor .......... 115

FIGURA 13 - Página do Course Management .................................................... 116

FIGURA 14 - Página inicial do curso da disciplina SEM-387 ........................... 119

FIGURA 15 - Ferramenta chat ..................................................................... 119

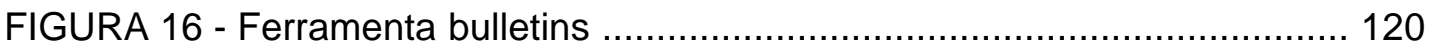

FIGURA 17 - Os links "help" e "contents" da Homepage .................................. 121

FIGURA 18 - Página do curso que é aberta pelo ícone "contents" .................... 121

FIGURA 19 - Página principal do Módulo 3 ..................................................... 124

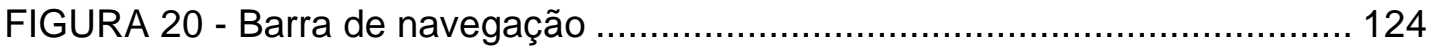

FIGURA 21 - Exemplo de navegação através dos botões "pg fwd" e "pg back" .. 126

FIGURA 22 - Botões de navegação presentes em algumas páginas ................. 126

FIGURA 23 - Modos de navegação em um módulo ........................................ 127

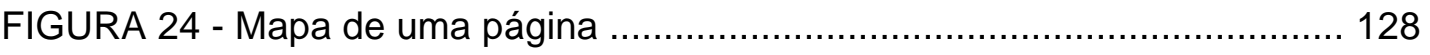

FIGURA 25 - Uma das planilhas que o usuário pode fazer download ................ 129 


\section{LISTA DE TABELAS}

TABELA 1 - O velho e o novo paradigma (SMITH \& WALLER, 1997) ................. 15

TABELA 2 - Alguns softwares educativos descritos na literatura ........................ 28

TABELA 3 - Algumas das principais ferramentas do WebCT ............................ 117

TABELA 4 - Os tópicos dos três módulos ..................................................... 123 


\section{RESUMO}

GUERRA, J.H.L. (2000). Utilização do computador no processo de ensinoaprendizagem: uma aplicação em Planejamento e Controle da Produção. São Carlos. 159p. Dissertação (Mestrado) - Escola de Engenharia de São Carlos, Universidade de São Paulo.

O conhecimento experimentado nas últimas décadas é tão expressivo que nem o professor e tampouco o aluno são capazes de adquiri-lo ou gerenciá-lo nos moldes tradicionais. No ensino superior, um dos problemas a ser resolvido reside na atitude passiva com que os alunos recebem o conhecimento de seus professores. Na sala de aula, a interface professor-aluno é mantida por um planejamento de ensino que privilegia a simples transmissão de conhecimentos. A utilização de algumas tecnologias, onde se destaca o computador, vem permitindo que 0 processo de ensino-aprendizagem sofra sensíveis transformações. $O$ computador, deixando o estigma de calculadora sofisticada, começa a ser empregado na construção do conhecimento. Procurando discutir essa questão, este trabalho analisa, em termos de recursos, exigências e limitações, como o computador pode contribuir para melhorar o processo de ensino-aprendizagem na educação em engenharia. Conhecimentos resultantes dessa análise foram reunidos na criação de um ambiente de aprendizagem na Web, desenvolvido através do software WebCT e tendo como domínio de aplicação a disciplina SEM387 "Planejamento e Controle da Produção I", do curso de Engenharia de Produção da EESC-USP. Melhorar o processo de ensino-aprendizagem não é um atributo inerente ao computador, mas uma conseqüência que está vinculada ao modo como ele é utilizado.

Palavras-chave: computador na educação; ensino-aprendizagem; Planejamento e Controle da Produção. 


\section{ABSTRACT}

GUERRA, J.H.L. (2000). Use of the computer in the teaching-learning process: an application in Planning and Control of the Production. São Carlos. 159p. Dissertação (Mestrado) - Escola de Engenharia de São Carlos, Universidade de São Paulo.

The knowledge experienced in the last decades is so expressive that neither the teacher nor the student is capable of acquiring it or managing it in the traditional way. Concerning college education, one of the problems to be solved is the passive attitude the students show when receiving the knowledge from their teachers. In the classroom, the interface teacher-student is maintained by a teaching planning that privileges the simple transmission of knowledge. The use of some technologies, among which the computer stands out, allows that the teaching-learning process suffers noticeable transformations. The computer, getting off the stigma of sophisticated calculator, begins to be used in the construction of the knowledge. Trying to discuss this subject, this work analyzes, in terms of resources, demands and limitations, how computers can contribute to improve the teaching-learning process in engineering education. The resulting knowledge of this analysis was gathered in the creation of a learning environment in the Web, developed through the software WebCT and having as application domain the discipline SEM-387 "Planning and Control of the Production I", which is a discipline of the course of Production Engineering of EESC-USP. Improving the teaching-learning process is not an inherent attribute of the computer, but a consequence that is linked to the way it is used.

Keywords: computer in the education; teaching-learning; Planning and Control of the Production. 


\section{Capítulo 1 - InTROducão}

O panorama mundial atual está sendo moldado por importantes mudanças e transformações, impulsionado pela onda da globalização. Sem querer entrar em uma discussão que defenda os benefícios ou enumere os prejuízos, o fato é que as mudanças políticas, sociais, organizacionais e culturais estão atingindo frentes nos quatro cantos do mundo e colocando em xeque valores, comportamentos e ações outrora tidos como tradicionais, alguns imutáveis. A velocidade e a amplitude das mudanças colocam homens, comunidades e nações em uma posição de iminente aceitação e concordância com as novas regras, já que o preço a ser pago para ficar fora do jogo é o da própria sobrevivência.

O avanço cada vez mais rápido do "estado da arte" das ciências, ocorrendo em todas as áreas do conhecimento, bem como a rápida evolução tecnológica, acabam por dividir indivíduos e empresas em duas classes: os dominantes e os dominados. Enquanto que ao primeiro é dedicada a tarefa da constante vigilância e concedido o direito à sobrevivência, o segundo fica com pouca autonomia e poder de barganha, entregue à sorte dos passos do primeiro. Apesar da grande diferença existente entre essas classes, a principal distância que as separa pode ser medida por um velho conhecido do homem, que o tem acompanhado desde seus primórdios: o conhecimento. Aliás, quando se fala em conhecimento, os verbos gerar e dominar nunca foram tão conjugados, tão essenciais e tão responsáveis pela segregação humana.

Diante de quadro tão complexo, a principal palavra de ordem é: prepararse. Mesmo considerando sua subjetividade e as dezenas de interpretações diferentes que essa palavra pode incitar, a verdade é que uma atitude de passividade diante de um cenário atual altamente dinâmico é uma escolha muito 
arriscada e fadada à extinção, enquanto que uma preparação adequada para as novas regras e o novo mundo, pelo menos em termos de criatividade, competência e inovação, resulta no caminho mais óbvio a ser seguido por nações, pessoas e organizações.

Em um mundo caracterizado pelo dinamismo crescente que avança em todas as direções, gerado pelo conhecimento e pela tecnologia, muitos são os personagens protagonistas. Um deles é a engenharia.

São indiscutíveis os benefícios que a engenharia trouxe à humanidade, melhorando e facilitando a vida das pessoas ao longo dos séculos. Também é inegável sua importância como fator estratégico crítico de desenvolvimento de toda nação. A engenharia tem participado direta ou indiretamente de muitas das importantes mudanças e transformações que assolam o mundo contemporâneo, criando, interferindo e contribuindo de forma efetiva para o progresso do homem.

O "fazer engenharia" é um processo constituído de várias etapas complementares e interdependentes, que são somadas sinergicamente de modo a construir o resultado final: a engenharia como ciência. Evidentemente, todas as etapas possuem uma importância vital, única e insubstituível. Atualmente, uma preocupação especial existe em relação à primeira das etapas, que é justamente a gênese de todo o processo: a educação em engenharia. Analisar e discutir até que ponto a educação em engenharia está preparada (ou está se preparando) para os novos desafios são ações que se tornam cada dia mais essenciais.

O ensino de engenharia hoje no Brasil é praticamente o mesmo dos anos 60 (MONSERRAT $\left.\mathrm{F}^{\circ}, 1995\right)$. As práticas e métodos usados no ensino tradicional, quando confrontados com o cenário atual, parecem não estar em sintonia com as mudanças e transformações que acompanham o resto do mundo, principalmente quando considerada a explosão da informação e do conhecimento. Disciplinas e cursos estagnados e desatualizados há vários anos (ou décadas) privam o aluno de uma formação mais condizente com a nova realidade profissional.

Segundo KURI (1998), o modelo de ensino tradicional, centrado na figura do professor - o responsável pela transmissão do conhecimento ao aluno -, apesar de estar cumprindo bem o seu papel, é pouco provável que forme profissionais aptos a responder a todos os desafios do novo cenário mundial. Para HARB et al. (1991), é preciso que os educadores cumpram muito mais que a tarefa de 
transmitir conhecimentos: é preciso ensinar aos alunos como aprender, para que estejam preparados para toda uma vida de aprendizagem.

Assim, é necessário buscar um novo paradigma para a educação em engenharia, onde o educador, deixando de ser a única fonte de informação e conhecimento, passe a criar oportunidades para que o aluno participe de forma mais ativa do seu processo de ensino-aprendizagem, sabendo como encontrar e filtrar a informação, bem como construir seu próprio conhecimento. Importantes mudanças começam a ocorrer na medida em que algumas tecnologias começam a ser entendidas e utilizadas como aliadas na busca desse novo paradigma.

Impulsionadas por avanços recentes, as tecnologias da informação e da comunicação estão sendo cada vez mais empregadas na educação. A utilização dessas tecnologias possibilita a criação de um caminho alternativo que liga o aluno ao conhecimento, favorecendo o desenvolvimento de novos métodos e práticas de ensino-aprendizagem.

Tradicionalmente utilizado como ferramenta para processar e transferir informações, e como elemento de apoio à tomada de decisões (BOARETTO Jr., 1996), o fato é que o computador passou a ser o grande elemento viabilizador e catalisador da utilização das novas tecnologias na educação. Para LIMA (1996), a utilização do computador permite novas formas de transmissão do conhecimento: métodos mais dinâmicos, interativos e atrativos, despertando no aluno a busca pela informação e sua participação efetiva no processo de ensino-aprendizagem.

Recursos que até pouco tempo atrás estavam distantes da maioria das pessoas e que hoje já fazem parte de um vocabulário bem conhecido, como o CDROM, o hipertexto, a multimídia e a hipermídia, são cada vez mais utilizados no desenvolvimento de sistemas computacionais de apoio ao ensino e treinamento, permitindo transformar o acesso à informação e a forma como ela é apresentada.

Além desses recursos, outro fator que vem impulsionando a aplicação do computador na educação é o avanço das redes de computadores, notadamente a maior delas: a Internet. Durante algum tempo confinada aos meios universitário e militar, a Internet cresce hoje a uma velocidade espantosa, quase imensurável, e seus recursos e serviços aumentam a cada dia. Além disso, os avanços nas tecnologias da informação e da comunicação estão melhorando o uso na rede de algumas ferramentas educacionalmente bem interessantes, como a multimídia. 
Por meio da Internet já é possível ter toda a informação do mundo dentro de casa. Qualquer pessoa que possua um mínimo dos recursos necessários pode acessá-la de qualquer lugar, a qualquer momento. Assim, mesmo existindo um caminho considerável a ser percorrido entre a transformação da informação crua em informação processada (ou seja, conhecimento), esse fato já caracteriza uma nova relação do homem com a busca e domínio do conhecimento.

O computador e a Internet permitiram revolucionar a chamada "educação a distância": uma forma de educação onde professor e aluno estão separados no tempo e no espaço, o aluno controla sua aprendizagem e a interação professoraluno é realizada por meios impressos ou eletrônicos.

Essa modalidade de educação, cada vez mais difundida, tem como uma de suas maiores vantagens permitir que a informação seja disseminada sem exigir do aluno o deslocamento de sua casa - ou seu trabalho - até o ambiente escolar. O desenvolvimento e a evolução dos métodos utilizados para propagar a informação, como é o caso das redes de computadores, têm contribuído de forma decisiva para seu sucesso e expansão.

Assim, o computador, favorecido pelos grandiosos avanços da tecnologia, principalmente da informação e comunicação, está permitindo que suas virtudes sejam canalizadas em direção à melhoria do processo de ensino-aprendizagem, desempenhando um importante papel na busca do novo paradigma da educação em engenharia.

Evidentemente, deve estar claro que a simples adição do computador não garante o sucesso da aprendizagem (ou do ensino), podendo inclusive amplificar os problemas e dificuldades existentes. Assim, seu uso na educação deve ser cuidadosamente planejado, visando sua harmonia com estratégias, técnicas e métodos de ensino que aproveitem suas potencialidades. Portanto, além de conhecer os recursos existentes ou disponíveis, é importante conhecer suas limitações e as exigências relacionadas com a sua utilização.

\section{1 - OBJETIVO}

Dentro deste contexto, o objetivo deste trabalho é analisar, em termos de recursos, exigências e limitações, como o computador pode contribuir para melhorar o processo de ensino-aprendizagem na educação em engenharia. 
Alguns conhecimentos resultantes dessa análise foram reunidos na criação de um ambiente de aprendizagem na Web, desenvolvido através do software WebCT e tendo como domínio de aplicação a disciplina SEM-387 "Planejamento e Controle da Produção I", do curso de Engenharia de Produção da Escola de Engenharia de São Carlos (EESC), da Universidade de São Paulo.

\section{2 - ESTRUTURA DO TRABALHO}

O trabalho está dividido em seis capítulos, incluindo este primeiro.

O Capítulo 2 discute o modelo tradicional de ensino empregado nas escolas de engenharia, onde o aluno é tratado como um recipiente vazio a ser enchido com conhecimento, e o novo paradigma que começa a tomar frente na educação, onde o aluno passa a ter o papel de construtor do conhecimento. $O$ capítulo também discute a importância e a participação das novas tecnologias (e, principalmente, do computador) no novo paradigma, bem como apresenta de forma breve o Ciclo de Aprendizagem, que pode servir como modelo de referência para o professor que pretende introduzir o computador no processo de ensinoaprendizagem.

O Capítulo 3 destaca que a utilização do computador vem crescendo muito na educação e no treinamento. Alguns recursos, como o CD-ROM, o hipertexto, a multimídia, a hipermídia e a Internet, por possuírem características interessantes sob o ponto de vista educacional, estão contribuindo significativamente para esse crescimento, servindo como elementos catalisadores. Assim, é feita uma descrição de cada um deles, onde são discutidas suas principais vantagens e desvantagens.

Se o objetivo realmente for melhorar o processo de ensino-aprendizagem, é fundamental considerar as exigências e limitações relacionadas com a utilização das novas tecnologias na educação. Essa questão é discutida no Capítulo 4, que trata também da educação a distância, cujo crescimento está sendo impulsionado principalmente pela Internet. A questão das exigências e limitações é obrigatória no caso da educação a distância, por causa de sua estreita ligação com a tecnologia. Indo mais além do que chamar a atenção para esse fato, o capítulo aproveita e discute as principais características dessa modalidade de educação, bem como o papel que ela poderá desempenhar no país. 
Algumas questões e discussões levantadas nos capítulos anteriores foram reunidas no desenvolvimento de um ambiente de aprendizagem na Web. $O$ Capítulo 5 descreve esse ambiente, bem como o software que foi utilizado para desenvolvê-lo, o WebCT.

Finalmente, no Capítulo 6 são apresentadas as principais conclusões deste trabalho, além de recomendações para trabalhos futuros, visando a continuidade desta linha de pesquisa. 


\section{Capítulo 2 - O Computador e um Novo Paradigma para a Educaç̃o em EngenHaria}

Em toda sua existência, o ser humano passou por inúmeras evoluções e transformações, seja de ordem física, cultural ou política. Apesar de todas as mudanças, alguns hábitos acompanharam o homem durante toda sua história, desde seu aparecimento, permanecendo implícitos à sua existência de uma forma tão direta e profunda que parecem movidos pelo próprio instinto - aquele mesmo que ordena ao homem comer e se reproduzir. É o caso da busca e domínio do conhecimento.

Presente na evolução da arte da guerra, na conquista do poder, nas grandes navegações, no tratamento das doenças, na melhoria das condições de vida da humanidade e nas tecnologias, o conhecimento é o combustível básico e obrigatório das ações humanas. Ao longo da história, o poder de um povo ou nação sempre foi medido pela sua capacidade de geração e domínio do conhecimento, ao contrário dos outros animais, onde poder é sinônimo de força física.

Uma "Era do Conhecimento" está presente e representa um divisor de águas entre o dominante e o dominado. Não dominar o conhecimento significa para o indivíduo estar relegado a um papel profissional e social secundário e sem perspectivas. Para uma empresa, gerar e dominar o conhecimento representam condições necessárias para sua sobrevivência.

O conhecimento vem crescendo a taxas exponenciais, exigindo de empresas e nações montantes cada vez maiores de investimentos em pesquisa e 
desenvolvimento, com vistas à melhoria de produtos e processos. Hoje não basta saber mais que o concorrente, mas também é necessário saber antes.

Personificação atual mais marcante do conhecimento, a tecnologia vem sendo intensamente utilizada tanto no ambiente das indústrias e empresas de serviços, quanto no cotidiano das pessoas mais simples. A penetração da tecnologia nas ações e atividades humanas ganhou uma dimensão tão natural e transparente, que as evoluções e transformações trazidas por ela já não causam tanto espanto e muitas vezes passam despercebidas. A tecnologia, seja embutida em uma máquina ou em um utensílio doméstico, já se tornou uma prótese - em alguns casos, cognitiva - do homem.

Atualmente, o domínio da tecnologia representa uma vantagem competitiva imprescindível para as organizações, já que permite revolucionar processos e projetos, alcançar mais resultados com menos tempo e capital, favorecendo o aumento da produtividade e, consequentemente, da sua competitividade no mercado.

Para BELHOT (1997a, p.1), "a tecnologia é o ponto central de uma revolução, que tem como aliados a rede mundial, os softwares e os computadores. As tecnologias da informação e da comunicação derrubaram, literalmente, as fronteiras entre países, criando novas oportunidades de mercado e trazendo atrelada a si uma maior concorrência. A concorrência que era local, regional ou estadual, agora já é internacional". Assim, cada vez mais as empresas reconhecem a importância da tecnologia para a sua competitividade e buscam uma capacitação em gestão tecnológica.

O desenvolvimento de novas tecnologias, principalmente aquelas mais complexas, é cada vez mais dependente de um tipo particular de conhecimento - o científico. Esse fato, aliado à rápida diminuição do ciclo de vida da tecnologia, o que significa investimentos cada vez maiores tanto em volume quanto em frequência, acabam por enaltecer as diferenças entre empresas e entre indivíduos quando o fator de comparação é o nível de competência tecnológica. Isso causa a um o fracasso comercial e financeiro, e ao outro, o analfabetismo tecnológico.

Conforme afirmam LONGO \& TELLES (1998, p.74): "diante dessa dinâmica de um mundo em constante mutação graças aos avanços da ciência e tecnologia, a imagem que se formula é que tudo se passa como se estivessem indivíduos, empresas e nações correndo sobre uma esteira que se desloca em sentido 
contrário ao deslocamento de todos, sendo necessário cada vez correr mais para permanecer no mesmo lugar. Caso não acompanhem ou suplantem a esteira da evolução científica tecnológica, os indivíduos tornam-se profissionalmente obsoletos, as empresas perdem competitividade e vão à falência, os países amargam o subdesenvolvimento e uma insuportável dependência externa do insumo mais estratégico do mundo moderno: o conhecimento".

Ainda segundo esses autores, existe um hiato entre os avanços científico e tecnológico e a capacidade de reação e reorganização dos grupos ou entidades sociais. Entre esses grupos estão desde o governo e as empresas, até os partidos políticos e as próprias universidades.

Em um mundo cada vez mais competitivo e sedento por novas tecnologias - muitas vezes utilizadas de forma indiscriminada e não apropriada -, a carência do emprego revela-se como um dos maiores problemas atuais, não mais enfrentado apenas pelos países miseráveis, mas também pelos do primeiro mundo, donos dos grandes conglomerados industriais e transnacionais. Para os trabalhadores, já é imperativo buscar novas oportunidades e formas de trabalho, ao invés de simplesmente explorar as já existentes.

A concorrência baseada na utilização da tecnologia e na geração e domínio do conhecimento gera um quadro mercadológico quase selvagem, exigindo das empresas (e das organizações de modo geral) inúmeras competências que, se até pouco tempo atrás não eram necessárias, hoje são requisitos fundamentais para garantia da sobrevivência.

As empresas, por sua vez, acabam transferindo parte dessa exigência de novas competências aos seus funcionários, tanto sob a forma de contratação de novos perfis profissionais, mais condizentes com a nova realidade, como na forma de treinamentos e políticas de capacitação profissional.

Por estar na linha de frente das empresas, assumindo a responsabilidade por decisões e ações estratégicas do qual dependem o presente e o futuro da empresa, é natural que a engenharia acabe sofrendo conseqüências diretas desse processo de busca de novos perfis profissionais. Tanto é assim que algumas competências são cada vez mais exigidas dos profissionais de engenharia, como forma de adequação desses recursos humanos à atual conjuntura, gerando condições potenciais para a empresa sobreviver e competir em seu mercado. Baseado em UNIVERSIDADE FEDERAL DE MINAS GERAIS (1995), SILVEIRA, 
MEIRELLES \& SILVA (1995) e LONGO \& TELLES (1998), algumas dessas competências estão citadas a seguir:

- capacidade para perceber e exercer a importância social e ambiental da engenharia;

- capacidade de expressão escrita, oral e icônica;

- capacidade de pensar de forma holística, ter uma visão sistêmica;

- capacidade para a solução de problemas;

- capacidade de comunicação oral e escrita em mais de uma língua, uma delas sendo necessariamente o inglês;

- capacidade para trabalhar em equipe;

- saber cultivar a liderança;

- capacidade empreendedora;

- capacidade para vencer os desafios da constante e rápida evolução do conhecimento científico e tecnológico;

- ser auto-reciclável (aprender a aprender): capacidade para aquisição e atualização autônoma e permanente da informação e do conhecimento;

- ser criativo;

- ser um cidadão do mundo (pensar e agir sem fronteiras).

Evidentemente, o ideal é que essas características ou competências sejam formadas ou conquistadas o mais cedo possível, profissionalmente falando, de forma que o engenheiro possa se adequar rapidamente às exigências do atual cenário. Assim, é natural e procedente que as cobranças e exigências recaiam sobre a própria educação em engenharia praticada nas escolas e universidades, pois a educação representa efetivamente o ponto inicial de todo o processo.

O panorama mundial apresenta atualmente um comportamento bastante dinâmico, com grandes e importantes transformações ocorrendo nas áreas política, econômica, cultural e social, e em todos os ramos do conhecimento. A onda gerada pelas mudanças acaba atingindo o mundo todo, como conseqüência de um avassalador efeito cascata que está subordinado às regras da própria sobrevivência.

Comparando o cenário atual com as estratégias, práticas e métodos de ensino empregados nas escolas de engenharia brasileiras, cria-se a sensação de 
que o atual modelo de ensino parece não estar orientado para preparar o profissional exigido pelo mundo moderno, principalmente quando considerada a explosão cada vez maior da informação e do conhecimento. Conforme defende RIBAS (1996), parece existir um descompasso entre o ensino e a evolução tecnológica.

Apesar do corpo docente estar mais bem qualificado que no passado, nem sempre se nota nos professores uma preocupação com questões curriculares e pedagógicas (STEFFEN Jr., 1997). Segundo CARDOSO (1998), os professores sempre utilizam os mesmos tipos de aula e as mesmas abordagens educacionais, sem praticamente inová-los.

Estratégias de ensino inadequadas e que têm permanecido resistentes a mudanças há décadas, tão comuns em escolas e universidades, desprezam o aumento cada vez maior da informação e do conhecimento e os novos atributos profissionais. Como conseqüência inevitável, os alunos acabam saindo da escola desatualizados e, não raro, despreparados.

\section{1 - O MODELO DE ENSINO TRADICIONAL}

De acordo com KURI (1993), no modelo tradicional de ensino empregado nas escolas de engenharia, a aquisição do conhecimento se realiza por meio da transmissão. Sua principal característica é a ênfase dada à figura do professor: ele é a fonte das informações, o especialista. Ele quem determina o nível e o ritmo da aula, os conteúdos, a metodologia e a avaliação. A relação professor-aluno é vertical.

Diante do professor permanecem os alunos, passivos-receptivos, ocupados em ouvir e anotar. A comunicação é unilateral, as perguntas dos alunos são raras e os comentários paralelos indesejáveis. As tarefas de aprendizagem são padronizadas, sem a consideração das diferenças individuais. Os alunos devem trabalhar no mesmo ritmo, repetir as mesmas informações e adquirir os mesmos conhecimentos. Eles somente executam atividades e tarefas que são propostas por autoridades superiores a eles. Um esquema simplificado do ensino tradicional é mostrado na figura 1.

Assim, no atual modelo o conhecimento é reproduzido, e não construído. Além disso, segundo MARTINS F (1997), a estrutura acadêmica de graduação é 
rígida, envolvendo uma grade horária de estudos muitas vezes sem flexibilidade para acomodar e incentivar o estudo em áreas complementares, ou a busca de informações em fontes alternativas.

Esse modelo está apoiado quase que exclusivamente na prática da aula expositiva, cuja forma praticamente não sofreu modificações, apesar da evolução dos meios de comunicação e do aparecimento de novos recursos de auxílio ao professor no ambiente da sala de aula. BIONDI NETO \& CHIGANER (1998) comentam que os recursos colocados à disposição do professor pela nova sociedade (a sociedade da informação), foram, de modo geral, sub-utilizados ou simplesmente ignorados. Para LI (1997), em muitas escolas de engenharia o quadro-negro e o giz continuam sendo as principais tecnologias de ensino.

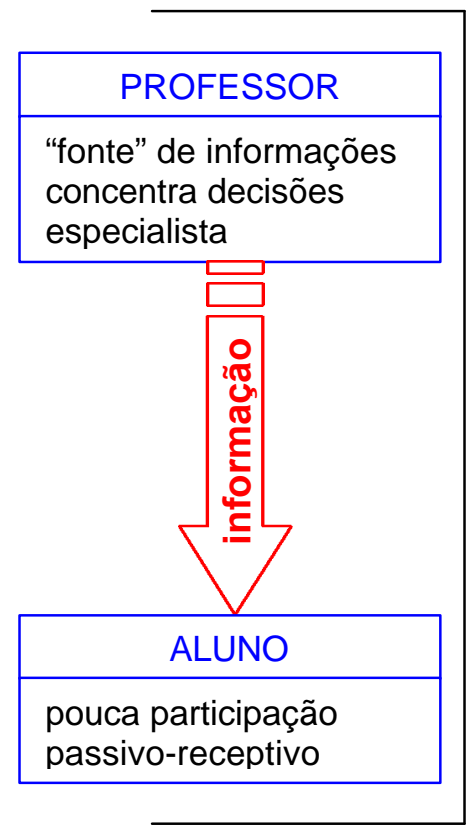

Comunicação unilateral

Tarefas de aprendizagem padronizadas

Conhecimento é reproduzido pelo aluno

FIGURA 1 - O ensino tradicional

De acordo com KURI (1993), o ensino apoiado exclusivamente na aula expositiva cumpriu seu papel de forma aceitável durante uma época em que os conhecimentos a serem transmitidos eram relativamente estáveis, e o conjunto de conhecimentos a ser adquirido pelo engenheiro não necessitava ser renovado durante sua vida profissional. No entanto, com a rapidez das mudanças científicas e tecnológicas, os objetivos formativos tornaram-se prioritários em relação aos informativos na formação dos novos profissionais engenheiros. 
A grande quantidade de informação que está sendo criada ultrapassa a capacidade de absorção de docentes e discentes. Isso provoca uma conseqüência profunda sobre a relação professor-aluno: ao contrário do que acontecia no passado, não se pode mais exigir que o professor domine todo o conteúdo da disciplina que ministra (FEHR, 1996).

BELHOT (1997a) afirma que no ensino tradicional a aprendizagem está baseado na solução de problemas "escolhidos", através da aplicação de uma seqüência de passos pré-estabelecidos. Assim, o ensino ocorre mediante um "livro de receitas", onde o ponto principal é o acúmulo de conhecimento e sua reprodução em atividades controladas, definidas ou estruturadas.

Para PALADINI (1996), a escolha do modelo atual de ensino sobre outras alternativas deve-se basicamente a dois fatores: em primeiro lugar, é um método que exige pouco do professor, não requer processos criativos de apresentação de conceitos ou fórmulas, nem tampouco atualização das aulas. O segundo fator sucede o primeiro, referindo-se à comodidade do professor: esse método de ensino, via transmissão de conhecimento a partir de quem o detém, é adequado a quem ensina, e não a quem aprende.

\section{2 - UM NOVO PARADIGMA}

RIBAS (1996) defende que, considerando a complexidade e as rápidas mudanças do mundo moderno, é insustentável a utilização de um modelo de ensino baseado na simples transmissão de conteúdos.

Diante de um cenário de quase estagnação do modelo tradicional de ensino, do conteúdo cada vez mais perecível da informação e do conhecimento, do rápido avanço científico e tecnológico, das novas realidades do mercado de trabalho, além dos novos problemas e desafios do mundo atual, cria-se a expectativa pela chegada de um novo paradigma para a educação em engenharia.

Nesse novo paradigma, o foco deverá mudar do ensino (instrução) para a aprendizagem, os objetivos formativos serão mais importantes que os informativos, o conhecimento será construído e não reproduzido e o aluno sairá de sua posição passiva e tomará uma posição ativa, pois segundo BORGES \& VASCONCELOS (1997, p.20), a aprendizagem só se consolida "se o estudante desempenhar um papel ativo de construir o seu próprio conhecimento e experiência, ainda que com 
a orientação e participação do professor". De acordo com PALADINI (1996), se a colocação do aluno em uma postura ativa durante a transmissão de informações não puder ser considerada uma proposição nova na relação de ensinoaprendizagem, pode-se pelo menos considerá-la pouco utilizada na prática do diaa-dia das universidades.

No novo paradigma, o aluno deverá desenvolver a habilidade de aprender a aprender, ou seja, ter capacidade de atualização contínua, de apropriar-se do conhecimento, sabendo de quais fontes obter a informação e como filtrá-la. Assim, o aluno estará mais bem preparado para lidar com o crescimento exponencial da informação e com a evolução cada vez mais rápida do conhecimento científico e tecnológico - situações que fatalmente enfrentará durante a sua vida profissional.

O educador, por sua vez, deixará de ser o "provedor" da informação e do conhecimento e passará ao papel de "facilitador" da aprendizagem, orientando e fornecendo oportunidades para que o próprio aluno busque a informação - onde quer que ela se encontre - e transforme-a em conhecimento, dentro de uma postura ativa, reflexiva e criativa.

Para BELHOT (1997a), a substituição do paradigma do ensino pelo da aprendizagem valoriza e estimula o que o aluno precisa aprender, e não apenas o que o professor pode ensinar. Além disso, no novo modelo:

- a atividade de ensino, que no modelo tradicional é voltada ao professor, deverá ser mais interativa e voltada ao aluno;

- o professor mudará seu papel de narrador de fatos e especialista, para o de colaborador, facilitador e até aprendiz;

- o aluno mudará seu papel de ouvinte passivo para o de colaborador ativo;

- o conhecimento será associado à capacidade de transformação da informação em novos comportamentos;

- o trabalho será voltado para o grupo, para o coletivo, e não mais para o individual;

- o conceito de quantidade será substituído pelo de qualidade;

- a tecnologia deverá ser tratada como um complemento ao currículo, evitando-se a veneração. 
LENSCHOW (1998), indo mais além do que comentar sobre a necessidade de um novo modelo, defende que o rápido desenvolvimento da tecnologia da informação é um indicativo de que uma mudança de paradigma já teve início na educação em engenharia. Segundo esse autor, as mudanças trazidas pelo novo paradigma ocorrem de forma integrada com as mudanças da tecnologia, principalmente da comunicação e da informação.

SMITH \& WALLER (1997) também defendem que uma mudança de paradigma está tomando frente na educação em engenharia, e fazem uma comparação entre o novo modelo e o "velho" modelo que está sendo substituído. Essa comparação está mostrada na tabela 1.

TABELA 1 - O velho e o novo paradigma (SMITH \& WALLER, 1997)

\begin{tabular}{|c|c|}
\hline VELHOPARADIGMA & NOVOPARADIGMA \\
\hline Conhecimento étransferido ao aluno & Aluno participa da construção do conhecimento \\
\hline $\begin{array}{l}\text { Aluno é visto como recipiente vazio a ser "enchido" com } \\
\text { conhecimento }\end{array}$ & $\begin{array}{l}\text { Aluno é descobridor, transformador e construtor ativo do } \\
\text { conhecimento }\end{array}$ \\
\hline Aprendizagem baseada na memorização & Aprendizagem baseada no relato \\
\hline Objetivo da escola é classificar e selecionar os alunos & $\begin{array}{l}\text { Objetivo da escola é desenvolver as competências e os } \\
\text { talentos dos alunos }\end{array}$ \\
\hline $\begin{array}{l}\text { Meta do aluno é completar requisitos para passar nas } \\
\text { disciplinas }\end{array}$ & $\begin{array}{l}\text { Meta do aluno é aprender, desenvolver competências e } \\
\text { experiências }\end{array}$ \\
\hline $\begin{array}{l}\text { Educação é conduzida dentro de um contexto de } \\
\text { relaçoes impessoais entre os alunos e entre os alunos e } \\
\text { o professor (aluno e professor são vistos como peças } \\
\text { intercambiáveis e substituíveis da "máquina } \\
\text { educacional") }\end{array}$ & $\begin{array}{l}\text { Professor e alunos trabalham juntos, fazendo da } \\
\text { educação uma forma de relacionamento pessoal }\end{array}$ \\
\hline $\begin{array}{l}\text { Ambiente competitivo e individualista dentro da sala de } \\
\text { aula }\end{array}$ & $\begin{array}{l}\text { Ambiente de aprendizagem cooperativo dentro da sala } \\
\text { de aula, possibilitando o desenvolvimento de talentos e } \\
\text { a construção ativa da aprendizagem }\end{array}$ \\
\hline $\begin{array}{l}\text { Classe é assumida como tendo uma uniformidade } \\
\text { cultural }\end{array}$ & $\begin{array}{l}\text { Diferenças entre os alunos são usadas para eniquecer } \\
\text { as experiências pessoais }\end{array}$ \\
\hline Escola concentra e exerce poder, autoridade e controle & Alunos participam das decisões \\
\hline $\begin{array}{l}\text { Avaliação com poucos formatos, geralmente } \\
\text { acontecendo apenas no meio e no final do curso }\end{array}$ & $\begin{array}{l}\text { Avaliação possui vários formatos (escrita, oral, em } \\
\text { grupo, etc), ocorrendo com mais frequência }\end{array}$ \\
\hline $\begin{array}{l}\text { Argumentos lógicos e racionais são os únicos aceitos; } \\
\text { dados devem ser objetivos e quantitativos }\end{array}$ & $\begin{array}{l}\text { Intuição e experiências pessoais são avaliadas; dados } \\
\text { qualitativos são avaliados em adição aos quantitativos }\end{array}$ \\
\hline Reducionista; fatos e memorização & Construtivista; investigação e invenção \\
\hline $\begin{array}{l}\text { Discurso e giz são suficientes (resistência ao uso da } \\
\text { tecnologia) }\end{array}$ & $\begin{array}{l}\text { Tecnologia tem um grande potencial para melhorar o } \\
\text { ensino e a aprendizagem }\end{array}$ \\
\hline Qualquer especialista pode ensinar & $\begin{array}{l}\text { Ensinar é uma atividade complexa que requer muito } \\
\text { treinamento e esforço }\end{array}$ \\
\hline
\end{tabular}




\section{3 - O NOVO PARADIGMA E A TECNOLOGIA}

Na busca de um novo paradigma para a educação em engenharia, a tecnologia deverá ocupar um papel de destaque, tendo uma contribuição efetiva e decisiva na medida em que:

- permitir quebrar as paredes e os muros das escolas, expandindo as fronteiras do conhecimento;

- favorecer a criação de novos meios de acesso e apresentação da informação;

- permitir novas posturas no ensino e na aprendizagem;

- possibilitar novas formas de relacionamento entre as pessoas.

Na dimensão do processo de ensino-aprendizagem, a grande vantagem na utilização da tecnologia está relacionada ao fato dela permitir um novo caminho de acesso ao conhecimento, onde o aprendiz (aluno, usuário) passa a ser construtor do seu próprio conhecimento, interferindo ativamente na busca da informação e no seu processo de aprendizagem, conforme ilustrado na figura 2. Para BELHOT (1997a), esse novo caminho criado pela tecnologia muda fundamentalmente a relação de ensino, fazendo com que o professor deixe de ser o único elo com o conhecimento.

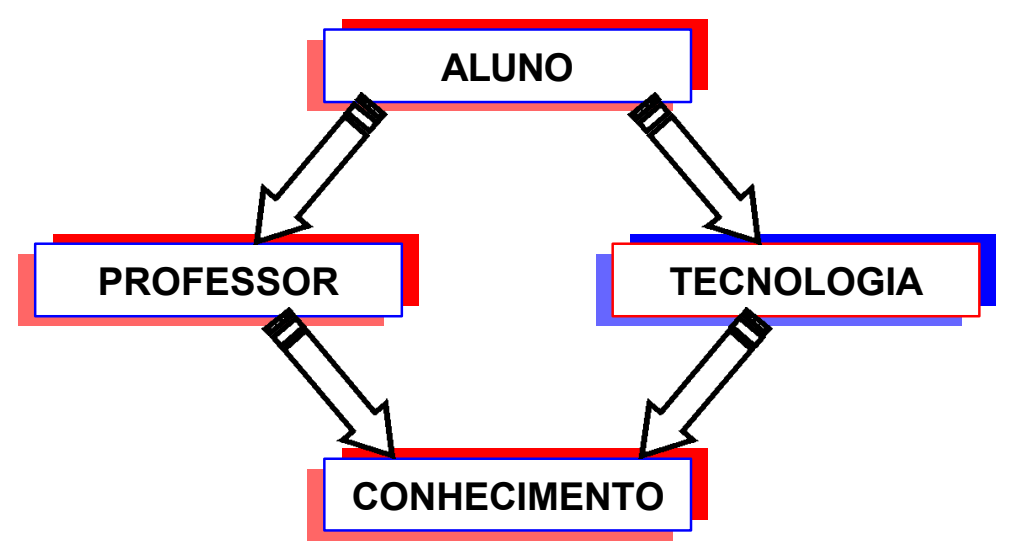

FIGURA 2 - A tecnologia cria um novo caminho até o conhecimento (modificada de BELHOT, 1997a, p.75) 
Evidentemente, deve estar claro que o aluno não estará sozinho nesse caminho alternativo criado pela introdução da tecnologia: a presença do educador não apenas continuará existindo, como ainda será muito importante. No entanto, o educador substituirá seu papel de "fonte" de informações para o de "facilitador" da aprendizagem, dando condições para o aluno participar ativamente da busca do conhecimento.

Entre as tecnologias que merecem destaque, estão as tecnologias da informação e da comunicação. Para BELHOT (1997b), as novas tecnologias da comunicação e da informação permitem aumentar a confiabilidade e a qualidade do processo de transmissão do conhecimento, tanto no ensino tradicional, quanto na educação a distância. Assim, é necessário utilizá-las para a disseminação do conhecimento, bem como desenvolver sistemas computacionais de apoio ao ensino e treinamento que estimulem as pessoas a um diálogo interativo.

\section{O COMPUTADOR}

A evolução tecnológica exponencial dos computadores atuais, com suas imensas capacidades de processamento e memória, a popularização das redes de computadores, o desenvolvimento cada vez mais rápido de novos recursos de software e hardware para aplicação em praticamente todo tipo de necessidade, entre outros fatores, transformaram o computador no principal canal responsável pela introdução das novas tecnologias na educação: assim, o computador pode ser considerado o grande pivô tecnológico das mudanças e inovações que começam a ocorrer no processo de ensino-aprendizagem.

BELHOT (1997a) afirma que a utilização do computador como ferramenta de apoio está afetando o ensino tradicional, facilitando o acesso à informação, permitindo que novas experiências educacionais sejam criadas e dando origem a um novo perfil de estudante.

O rápido crescimento das redes de computadores, entre elas a Internet, e o desenvolvimento de novos equipamentos e serviços que melhoram a capacidade de comunicação, criam uma sala de aula mundial, permitindo que o aluno pesquise a informação de seu interesse onde quer que ela se encontre, além de transformar drasticamente a relação professor-aluno, quebrando limitações de tempo e espaço. 
Assim, por seus méritos e favorecido por outras tecnologias, o computador encontra-se numa posição de vanguarda na busca de um novo paradigma para a educação em engenharia. Porém, como forma de contribuir de forma efetiva nessa busca, é necessário que não apenas o computador, mas também as outras formas de tecnologia disponíveis, sejam estudadas, desvendadas e utilizadas dentro de uma estratégia que conquiste e amplie suas potencialidades.

Evidentemente, a simples introdução da tecnologia no processo de ensinoaprendizagem não caracteriza, por si só, uma mudança de paradigma e nem tampouco tem essa ambição: essa é uma postura que deve ficar absolutamente clara entre os educadores, principalmente entre os seus maiores defensores. Uma mudança de paradigma é algo muito mais profundo, que exige mudanças em termos de comportamento, conceitos, valores e ações, e uma mobilização por parte de todas as classes dos envolvidos. A tecnologia, portanto, se propõe a servir como um complemento auxiliar e sinérgico na busca e na adoção de um novo modelo, constituindo-se, assim, em um meio - não em um fim.

O item a seguir apresenta o chamado "Ciclo de Aprendizagem", bem como algumas considerações sobre a utilização do computador nas diferentes fases do Ciclo, o que permitirá localizar a proposta deste trabalho em termos de uma dessas fases.

\section{4 - O CICLO DE APRENDIZAGEM}

O Ciclo de Aprendizagem representa uma estratégia para o planejamento do ensino-aprendizagem. O Ciclo concebe a aprendizagem em quatro fases:

Fase 1: nessa fase é estabelecido um "sentido" para o assunto, é onde os alunos são motivados para aprender o tópico a ser ensinado. Assim, essa fase pode ser representada pela questão "Por quê?", já que, em termos gerais, o objetivo dessa fase é responder à pergunta: Por que é importante conhecer esse assunto? (Por que esse problema é importante?)

Fase 2: nessa fase é fornecida a informação aos alunos, ou seja, é onde a teoria e os conceitos são apresentados. Essa fase pode ser representada pela questão "O quê?", pois, em termos gerais, o objetivo dessa fase é 
responder à pergunta: $\underline{\mathrm{O} \text { que é preciso saber para dominar esse assunto }}$ ou resolver esse problema?

Fase 3: nessa fase os alunos são auxiliados a desenvolver modelos e técnicas para solução de problemas. Essa fase pode ser representada pela questão "Como?", já que, em termos gerais, o objetivo dessa fase é responder à pergunta: Como esse problema pode ser resolvido?

Fase 4: nessa fase são fornecidas ao aluno oportunidades para a autodescoberta, para a simulação de situações novas. Essa fase pode ser representada pela questão "E se?", já que, em termos gerais, o objetivo dessa fase é responder à pergunta: E se esse problema fosse resolvido de outra maneira? (E se isso fosse feito de forma diferente?). Segundo HARB et al. (1991), na fase anterior o professor estabelece os procedimentos para a solução do problema, enquanto que nessa última os alunos aplicam esses procedimentos em situações novas.

Uma representação do Ciclo de Aprendizagem é mostrada na figura 3. Para que a aprendizagem ocorra, é preciso uma movimentação pelo Ciclo: ou seja, professor e alunos devem caminhar pelas suas quatro fases. Em termos gerais, caminhar pelo Ciclo significa responder às quatro questões ("Por quê?"; "O quê?"; "Como?"; "E se?”) de forma seqüencial. Depois de atingida a última fase, o Ciclo pode ser reiniciado, já que o processo é contínuo.

O Ciclo representa um processo estruturado e ordenado. Para que ocorra a movimentação através do Ciclo é necessário escolher os métodos, as técnicas e os recursos instrucionais adequados para cada fase, considerando as restrições ambientais (BELHOT, 1997a).

Existem muitas atividades que podem ser utilizadas pelo docente e que são apropriadas para cada fase do Ciclo. Segundo HARB et al. (1991), podem ser preparadas questões para criarem nos alunos a motivação para aprender ("Por quê?"), a exposição para transferir a informação (“O quê?"), o treinamento para auxiliar os alunos a trabalharem sozinhos ("Como?") e a simulação para testarem novas situações ou problemas reais ("E se?"), por exemplo. Baseado nesses 
mesmos autores, estão explicitadas a seguir algumas das atividades que podem ser utilizadas nas diferentes fases do Ciclo:

- Fase 1 ("Por quê?"): relato de experiências/casos, discussão em grupo, discussão em classe;

- Fase 2 ("O quê?"): aulas expositivas, demonstrações realizadas pelo professor, problemas resolvidos pelo professor;

- Fase 3 ("Como?"): resolução de problemas pelos alunos, problemas para casa, laboratório dirigido;

- Fase 4 ("E se?"): problemas abertos, problemas formulados e resolvidos pelos alunos, laboratório.

Para HARB et al. (1991), as maiores vantagens relacionadas ao uso do Ciclo de Aprendizagem incluem a grande satisfação dos alunos e o apoio às metas educacionais: o desenvolvimento do raciocínio, a comunicação, a resolução de problemas e a auto-motivação. Para esses autores, o Ciclo fornece um modelo prático que os professores de engenharia podem usar como base para melhorar a instrução de seus alunos.

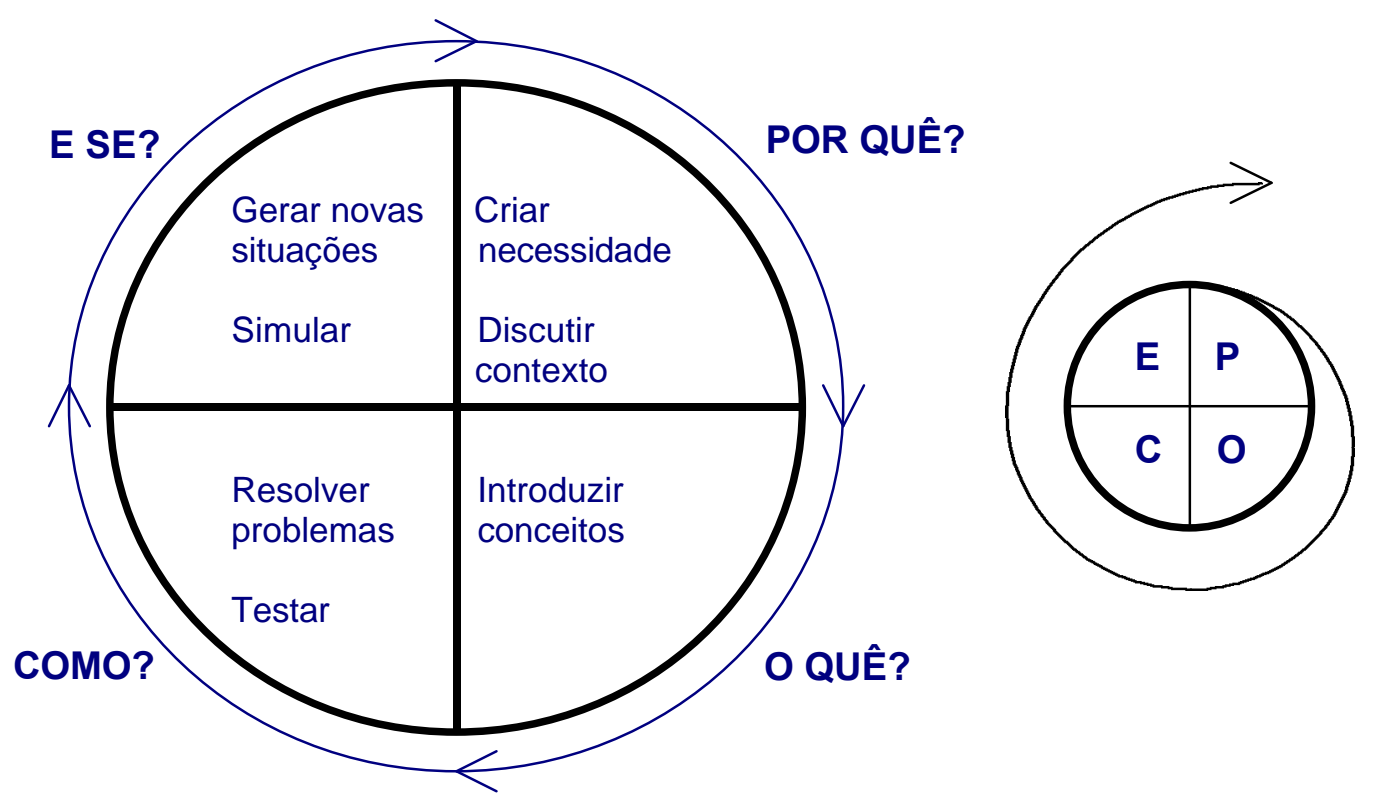

FIGURA 3 - O Ciclo de Aprendizagem 
Mais informações sobre o Ciclo de Aprendizagem podem ser obtidas, além de HARB et al. (1991), em STICE (1987) e HARB, DURRANT \& TERRY (1993). Também podem ser consultadas a obra de David Kolb (KOLB, 1984), que originou a teoria sobre o Ciclo de Aprendizagem, e a de Bernice McCarthy (McCARTHY, 1987), sobre o Sistema 4MAT de ensino.

\subsection{1 - O COMPUTADOR NO CICLO DE APRENDIZAGEM}

Para BELHOT (1997a), o computador pode ser um elemento valioso se utilizado em conjunto com o Ciclo de Aprendizagem. Para isso, é importante que seu uso ocorra em consonância com as diferentes fases do Ciclo.

Tradicionalmente, o computador tem sido utilizado como uma ferramenta para a solução de problemas, o que corresponde ao seu emprego na fase "Como?" do Ciclo (primeira forma de utilização do computador). Também tem sido utilizado, porém com menos intensidade, nos casos que exigem a análise de situações novas ou variações nas condições dos parâmetros do problema e da solução, o que corresponde ao seu emprego na fase "E se?" (representando uma primeira migração no uso do computador).

Os recentes avanços tecnológicos nas áreas de hardware e software, o aparecimento e a disseminação de recursos tais como o CD-ROM, o hipertexto, a multimídia, a hipermídia, entre outros, permitiram transformar o computador em um novo meio de acesso à informação e ao conhecimento, o que significa sua introdução em uma nova fase do Ciclo de Aprendizagem: a fase "O quê?", ou seja, no aspecto conceitual do ensino (representando uma segunda migração no uso do computador).

O desenvolvimento e a aplicação de novos softwares de simulação (como os que empregam a técnica de System Dynamics) estão provocando uma terceira migração no uso do computador, novamente para a fase "E se?". Porém, esses softwares também estão contribuindo de forma significativa para a aplicação da simulação dentro de uma abordagem construtivista, bem como permitindo o ensino e a aprendizagem de novos conceitos e teorias, representando, assim, uma quarta migração, novamente para a fase "O quê?". A figura 4 ilustra as migrações do computador em relação às diferentes fases do Ciclo. 


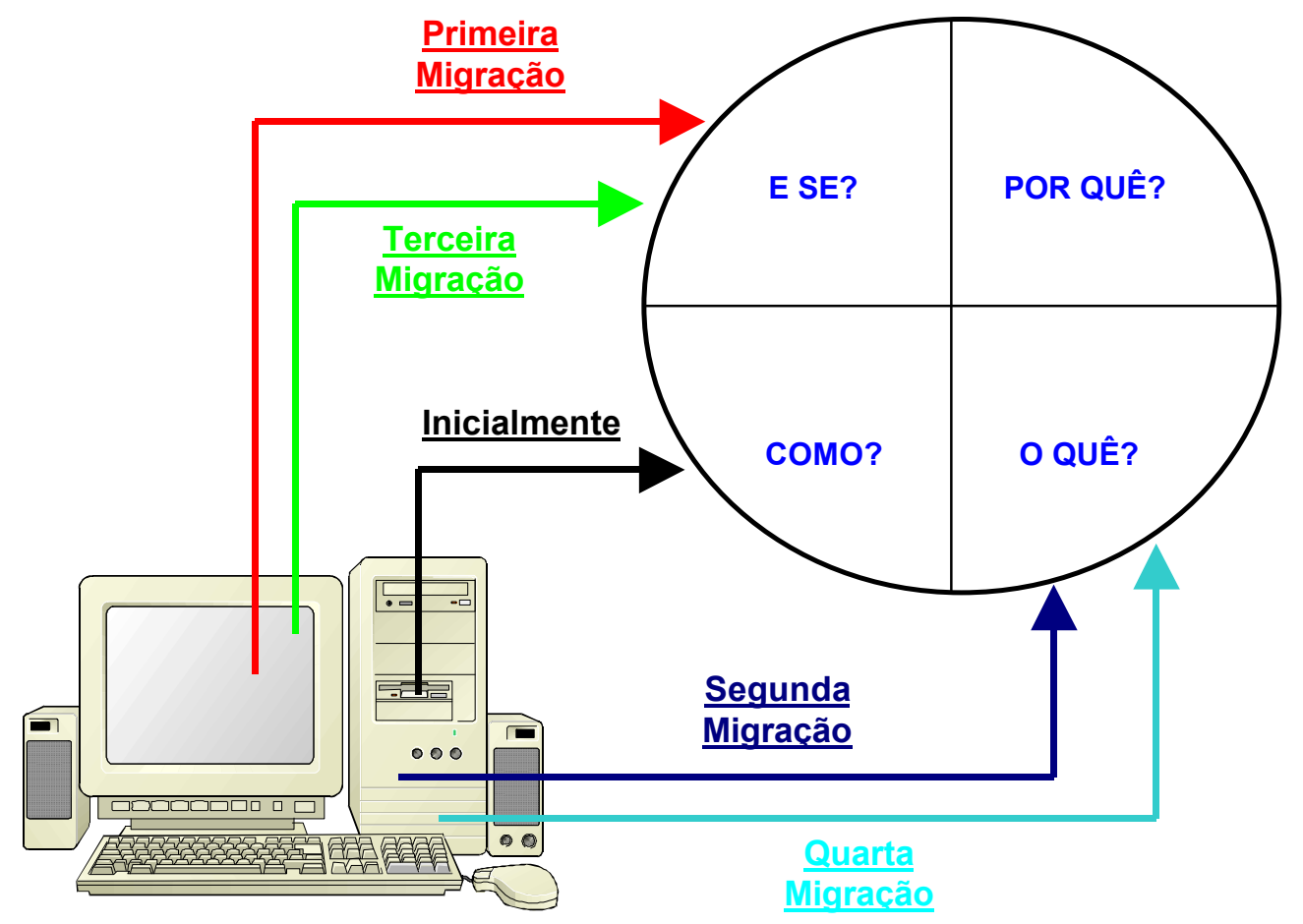

FIGURA 4 - O computador nas fases do Ciclo de Aprendizagem

\subsection{2 - O CICLO DE APRENDIZAGEM E A PROPOSTA DESTE TRABALHO}

Agora que foram descritas as fases do Ciclo e as migrações no uso do computador, poderá ser melhor compreendida a razão pela qual foi apresentada a teoria do Ciclo de Aprendizagem: a proposta maior deste trabalho, qual seja, analisar, em termos de recursos, exigências e limitações, como o computador pode contribuir para melhorar o processo de ensino-aprendizagem na educação em engenharia, está localizada, em termos do Ciclo de Aprendizagem, dentro da fase "O quê?". Assim, o que se busca aqui é analisar o uso do computador como recurso instrucional de apoio em uma atividade que, no modelo tradicional de ensino, é típica do professor (a apresentação de teorias e conceitos).

Como a fase "O quê?" já agrega duas migrações do computador (ver figura 4), convém esclarecer que este trabalho está interessado na segunda migração. Porém, considerando que o foco deste trabalho está precisamente localizado (fase "O quê?"; segunda migração), isso não significa que as suas discussões, questões ou conclusões perderão a validade quando o objetivo for analisar a utilização do computador nas outras fases do Ciclo. O computador é sempre o mesmo recurso, 
não importa em qual fase esteja sendo empregado. O que muda em cada fase é apenas a maneira como ele é utilizado. Assim, as questões e discussões são comuns, independente da fase do Ciclo ou da migração que o computador sofreu.

Além de localizar a proposta deste trabalho, a apresentação do Ciclo de Aprendizagem também teve o objetivo de descrever (ainda que brevemente) uma teoria que pode servir como fonte de referência para o professor que está pretendendo introduzir (ou já utiliza) o computador no processo de ensinoaprendizagem. No ensino tradicional (com ou sem computador), é comum somente as fases "O quê?" e "Como?" serem consideradas e executadas pelo professor dentro da sala de aula. A consideração das quatro diferentes fases do Ciclo, bem como todo o seu contexto, permite entender a aprendizagem sob uma perspectiva muito mais ampla. Cria-se, assim, um ambiente muito mais propício para que o computador e outras tecnologias possam contribuir para a melhoria do processo de ensino-aprendizagem.

Evidentemente, adotar o Ciclo é facultativo. O mais importante é chamar a atenção para que o professor tenha um modelo de referência quando for utilizar as novas tecnologias dentro do contexto educacional. 


\section{Capítulo 3 - O Computador no Processo de Ensino- Aprendizagem: Alguns Recursos}

Segundo CAZARINI (1992), com o surgimento do computador no meio empresarial no início da década de 50, o meio ambiente passou a sofrer alterações e a afetar, de forma geral, todas as profissões.

De acordo com esse autor, o computador foi inicialmente apresentado como um excelente auxiliar na realização de complexos cálculos. Em seguida, mostrou-se como importante ferramenta para engenheiros e cientistas. Depois atravessou uma etapa em que sua utilização estava restrita às universidades, grandes empresas e órgãos governamentais, devido aos altos custos envolvidos, o que tornava seu uso proibitivo para a grande massa de pequenos usuários. No ensino, sempre foi encarado como um dispositivo sofisticado e elitizante, que deveria ser utilizado com restrições, uma vez que nem toda a comunidade tinha à sua disposição essa tecnologia tão sofisticada. Dentro das universidades, seu uso era incentivado apenas para o desenvolvimento de pesquisas científicas.

Nos currículos dos cursos de graduação, foram introduzidas disciplinas cujo objetivo era ensinar aos alunos como utilizar o computador, através de linguagens de programação. Essas linguagens colocavam-se como interface entre o usuário e a linguagem de máquina.

Ainda segundo CAZARINI (1992), com o desenvolvimento obtido na área computacional e eletrônica, hoje existem facilidades e versatilidades que permitem aos computadores serem utilizados em outras tarefas, bem diferentes daquelas envolvendo apenas os cálculos complexos.

Um dos mais claros exemplos do crescimento da utilização do computador 
é dado pela própria área da educação, onde, desvencilhando-se do estigma de "calculadora sofisticada", o computador busca fundamentar-se como novo meio de acesso ao conhecimento. Esse crescimento, por sua vez, tem gerado uma grande discussão em torno do tema, permitindo que novas idéias, críticas, defesas e argumentos sejam levantados e analisados, buscando entender o computador sob a perspectiva da melhoria do processo de ensino-aprendizagem.

Essa discussão pode ser notada pelo aumento no número de publicações e eventos (congressos, conferências, workshops) sobre o tema em todo o mundo. Publicações seriadas especializadas no assunto ou não vêm tratando de gerar e difundir, bem como mostrar experiências envolvendo o uso do computador na educação. Considerando que o computador e seus recursos possuem um grande potencial educacional, evidentemente quando bem aplicados dentro de uma estratégia que aproveite suas vantagens, as discussões servem, no mínimo, para quebrar barreiras culturais discriminatórias envolvendo a tecnologia e como forma de dividir experiências visando vencer problemas e evitar insucessos.

Com o objetivo de dar uma contribuição a essa discussão, este trabalho irá descrever alguns recursos computacionais existentes e cada vez mais utilizados na educação, bem como discutirá algumas exigências e limitações envolvendo o uso do computador e outras tecnologias no processo de ensino-aprendizagem.

\section{1 - O COMPUTADOR E OUTRAS TECNOLOGIAS NA EDUCACÃO E NO TREINAMENTO}

\subsection{1 - NA EDUCAČ̃̃O}

As novas tecnologias da informação e da comunicação estão mudando o processo de aprendizagem e pesquisa (LANGLOIS, 1998). Para REINHARDT (1995), o crescimento explosivo dos drives (hardware) de CD-ROM, conexões com a Internet e ambientes de software colaborativo está impulsionando uma nova onda de ferramentas de ensino. Essa geração de novas tecnologias pode propiciar uma mudança qualitativa na própria natureza da aprendizagem.

O principal elemento tecnológico viabilizador das mudanças, o computador, configura-se hoje como uma ferramenta potencialmente capacitada para iniciar e difundir novas experiências e idéias dentro da educação, visando sua melhoria. 
Para FARIAS (1997), os computadores já são ferramentas indispensáveis para o processo educacional. LELOUCHE (1998) acredita que a classe tradicional poderá desaparecer, ou no mínimo ter sua extensão diminuída com a introdução dos computadores.

O computador e seus recursos possibilitam colocar os alunos em uma posição ativa de descobridores e construtores do seu próprio conhecimento, em um ambiente de aprendizagem que respeita suas diferenças individuais, na medida em que utiliza diferentes meios e formatos no tratamento e apresentação da informação. Cria-se, assim, um clima favorável para o desenvolvimento de novas competências e talentos.

Para o escritor italiano Umberto Eco (A INTERNET É A REVOLUÇÃO DO SÉCULO, 2000, p.8), "o computador e a Internet são a verdadeira revolução do século. Como a imprensa de tipos móveis de Gutenberg, eles podem modificar nossa maneira de pensar e aprender".

O advento do computador e o sucesso da Internet e da Web criaram novas formas de atrair os estudantes ao estudo (VIALI, 1999). Para MORAN (1995), os alunos e professores encontram na Internet recursos que facilitam a tarefa de preparar as aulas e fazer os trabalhos de pesquisa. Além disso, o professor tem condições de estar mais próximo do aluno, podendo adaptar sua aula ao ritmo de cada um. Problemas e novos programas da sua área de conhecimento podem ser compartilhados com outros professores.

De acordo com GARCIA (1997), as redes eletrônicas estão estabelecendo novas formas de comunicação e interação, onde a troca de idéias grupais, essencialmente interativa, desconsidera a questão física e temporal. As redes possuem a vantagem de trabalhar com grande volume de dados e transportar grandes quantidades de informação, em qualquer tempo, espaço e formato. Além disso, as redes são utilizadas no processo pedagógico para romper as paredes da escola, permitindo que professor e aluno conheçam novas culturas e realidades.

Ainda segundo GARCIA (1997), a utilização das redes eletrônicas leva a crer em uma nova dimensão qualitativa para o ensino, onde o ato educativo está voltado para uma visão mais internacionalizada e colaborativa. As redes também criam um ambiente atrativo onde o aluno é capaz, através da auto-aprendizagem e de seus próprios professores, de tirar proveito na sua preparação para a vida e o trabalho. 


\section{ALGUMAS EXPERIÊNCIAS}

O desenvolvimento de sistemas computacionais de apoio ao ensino (os chamados softwares educativos ou didáticos; ROCHA \& CAMPOS, 1993, citam outros termos equivalentes: programas educativos por computador e coursewares) vem conquistando largo espaço entre as instituições educacionais, desde o ensino fundamental até o superior.

Esses termos, em uma concepção mais ampla, englobam sistemas de diferentes tipos, tais como: tutoriais, sistemas multimídia, sistemas hipermídia, sistemas tutores inteligentes (também chamados de ICAI - "Intelligent Computer Aided Instruction"), entre outros (os sistemas computacionais de apoio ao ensino podem ser classificados de diferentes maneiras; ver VALENTE, 1993 e SANTOS, 1997, por exemplo).

Esses sistemas visam satisfazer diferentes necessidades, sendo utilizados tanto no ensino presencial tradicional quanto na educação a distância. Para MEDEIROS $F^{\circ}$ \& CINTRA (1999a), muitos deles são desenvolvidos para auxiliar o professor em sala de aula, outros além da sala de aula podem ser utilizados pelos alunos em tarefas extras, e também existem aqueles destinados a auxiliarem o aluno sem a ajuda ou o acompanhamento do professor. SILVEIRA \& ARRUDA (1998), por exemplo, desenvolveram um sistema para a área de controle e automação por causa da dificuldade de compreensão do assunto pelos alunos, falta de motivação, carência de módulos didáticos e da complexidade de integrar sistemas profissionais com a sala de aula. Assim, as características, importância, objetivos educacionais e a forma de utilização de um sistema vão variar de acordo com a situação, o ambiente e as necessidades a serem satisfeitas.

$\mathrm{Na}$ opinião de HÖLBIG et al. (1998), os computadores tornaram-se uma importante ferramenta no ambiente escolar, estimulando cada vez mais a criação de softwares educativos que servem de suporte às disciplinas escolares. Para MONTGOMERY (1995), uma das formas de se alcançar as diferenças individuais dos alunos é justamente através do uso de softwares educativos.

De acordo com AKAMATSU, SENNA \& LEITE (1997), os esforços de desenvolvimento de softwares educativos vêm se tornando cada vez menores, não devido apenas às ferramentas disponíveis, mas à grande disponibilidade, a 
baixo custo, de máquinas e periféricos. Além disso, os softwares estão ficando cada vez mais automáticos e amigáveis.

Considerando a facilidade, cada vez maior, em se produzir softwares de qualidade sem a necessidade de grandes investimentos financeiros ou de grandes espaços físicos, AKAMATSU, SENNA \& LEITE (1997) defendem que algumas universidades deveriam investir na criação de pequenos laboratórios para desenvolvimento de softwares educativos. Segundo PINHEIRO (1997), como a aprendizagem se faz pela construção do conhecimento, o desenvolvimento de tutoriais pelos próprios alunos pode ser uma técnica poderosa de ensino.

Algumas referências que descrevem experiências relacionadas com 0 desenvolvimento e aplicação de softwares educativos estão sugeridas na tabela 2.

TABELA 2 - Alguns softwares educativos descritos na literatura

\begin{tabular}{|c|c|}
\hline ASSUNTO & REFERÊNCIA \\
\hline Ferramenta multimídia para o ensino de matemática & BASTIEN, PIERRE \& CANTIN (1997) \\
\hline Sistema Tutor Inteligente para o ensino de sistemas de controle & CUNHA Jr. \& DOMINGUES (1998) \\
\hline Sistema TEA: sistema multimídia sobre economia agránia & BELMONTE, BERBEL \& CONEJO (1997) \\
\hline $\begin{array}{l}\text { Softwares educativos baseados em arquiteturas propostas pelo } \\
\text { autor }\end{array}$ & SCHANK (1994) \\
\hline $\begin{array}{l}\text { Descrição de uma ferramenta de autoria para Sistemas Tutores } \\
\text { Inteligentes }\end{array}$ & EBERSPÄCHER \& KAESTNER (1998) \\
\hline $\begin{array}{l}\text { Protótipo do sistema ACONSYS ("Authorship COntrol SYStem"), } \\
\text { para autoria e apresentação de cursos de controle }\end{array}$ & SILVEIRA\& ARRUDA (1998) \\
\hline $\begin{array}{l}\text { Softwares educativos multimília desenvolvidos para atingir } \\
\text { diferentes estilos de aprendizagem }\end{array}$ & MONTGOMERY (1995) \\
\hline $\begin{array}{l}\text { Ferramenta computacional multimídia para o ensino de } \\
\text { resistência dos materiais }\end{array}$ & MASUERO \& GONZÁLEZ (1998) \\
\hline $\begin{array}{l}\text { Ambiente pedagógico multimídia sobre a histónia do azulejo em } \\
\text { Portugal }\end{array}$ & AFONSO, DIAS \& MAIA (1998) \\
\hline $\begin{array}{l}\text { Módulos multimídia desenvolvidos dentro do projeto MEEP } \\
\text { ("Manufacturing Engineering Education Partnership") }\end{array}$ & GRIFFITHetal. (1997) \\
\hline $\begin{array}{l}\text { Sobre o manual interativo multimídia "The Telecommunications } \\
\text { Laboratory Manual" }\end{array}$ & SEARS \& WATKINS (1996) \\
\hline $\begin{array}{l}\text { Sobre o sistema CORAL ("COoperative Remotely Accessible } \\
\text { Leaming") }\end{array}$ & SUN\& CHOU (1996) \\
\hline $\begin{array}{l}\text { Pacote multimídia para o ensino de sistemas de prototipagem } \\
\text { rápida }\end{array}$ & CHUA etal. (1997) \\
\hline $\begin{array}{l}\text { Descrição do protótipo do ambiente de aprendizagem multimídia } \\
\text { SLICE ('Self-directed in an interactive computer environment') }\end{array}$ & HARMS, KRAHN\& KURZ(1998) \\
\hline $\begin{array}{l}\text { Ambiente SIATE ("Sistema Inteligente de Apoio ao Treinamento } \\
\text { e Ensino") }\end{array}$ & FREIRE (1998) \\
\hline $\begin{array}{l}\text { Sobre o sistema SASHE("Sistema de Autoria e Suporte de } \\
\text { Hipermídia para o Ensino") }\end{array}$ & SANTOS (1997) \\
\hline
\end{tabular}




\subsection{2 - NO TREINAMENTO}

O ambiente escolar não é o único a utilizar o computador como um importante recurso instrucional. A busca pela produtividade nas empresas acaba quase sempre significando uma escolha por equipamentos e processos dotados de inovações tecnológicas cada vez mais complexas. O descompasso existente entre o domínio das novas tecnologias e o preparo dos funcionários exige constantes e volumosos investimentos em treinamento, muitas vezes não condizentes com a realidade das empresas (principalmente das pequenas e médias) e sem o retorno esperado.

Mas não é apenas o domínio da tecnologia que reclama investimentos em treinamento. A necessidade de manter uma mão-de-obra qualificada, competitiva e cada vez mais produtiva, vem obrigando as empresas a investirem em cursos que exigem alto montante financeiro e que visam colocar seus engenheiros, gerentes e diretores em contato com as mais modernas práticas gerenciais. Muitas vezes é preciso o deslocamento do profissional para locais distantes, sendo comum o treinamento em outras cidades e até no próprio exterior (na matriz da empresa, por exemplo). Evidentemente, esses gastos extras encarecem ainda mais os custos. O baixo custo-benefício resultante desses altos investimentos vem forçando muitas empresas a buscarem novas alternativas.

No mundo atual, os profissionais precisam se adaptar rapidamente a diversos ambientes e situações, como tentativa de garantir seu lugar no mercado. Para REINHARDT (1995), os empregados estão mais dispersos geograficamente hoje do que antigamente, e a rotatividade é mais elevada. A tecnologia evolui tão rapidamente que exige freqüentes renovações das habilidades. Como resultado, muitas empresas estão procurando atrelar a aprendizagem ao próprio ambiente de trabalho.

Assim, na procura por alternativas novas e viáveis para treinar ou reciclar seus funcionários, as empresas estão cada vez mais passando a confiar na tecnologia, que tem oferecido uma diversidade de métodos para o autotreinamento (JUCÁ, 1997). Várias organizações do mundo todo (inclusive no Brasil) estão descobrindo que os computadores podem ser um professor paciente e disponível de acordo com a disponibilidade de horário e local dos profissionais 
(UM GURU EM CADA MESA DE TRABALHO, 1994). A idéia é transformar o ambiente de trabalho em uma sala de aula permanente. Sistemas especialistas, sistemas multimídia e hipermídia, cursos via rede Internet ou Intranet, bem como a utilização de CD-ROM's são algumas das alternativas que estão sendo utilizadas.

Uma solução que vem conquistando cada vez mais espaço, segundo JUCÁ (1997), é a utilização do chamado CBT ("Computer Based Training"): software que utiliza o próprio computador como ferramenta de apoio à aprendizagem. Segundo essa autora, o CBT evita os tradicionais problemas que ocorrem nos treinamentos coletivos, como a timidez e o receio de fazer perguntas em público. Ele pode ser utilizado tanto em salas especiais dotadas de computadores reservados à atividade de treinamento, quanto nas próprias mesas de trabalho dos funcionários.

Sua distribuição via rede ou CD-ROM a diferentes plantas da empresa (geograficamente dispersas) pode significar economia nos treinamentos, já que não exige o deslocamento dos profissionais para outros pontos. Além disso, o mesmo programa pode ser utilizado e repetido quantas vezes for necessário, sem custos adicionais, ao contrário dos treinamentos realizados da forma tradicional. $\mathrm{Na}$ verdade, a padronização do curso pode, em alguns casos, significar desvantagem que, somado ao alto custo de desenvolvimento de um CBT, resulte em obstáculos para a sua utilização. Outro problema, segundo RIVAS (1998), é que o CBT não permite interação com um professor ou instrutor, apenas com a própria tecnologia.

Uma outra solução que também vem ganhando espaço nas empresas é a videoconferência. Seu uso apresenta vantagens de tempo e dinheiro, já que evita o deslocamento físico dos funcionários para um local específico, reduz as despesas de viagem e permite que as reuniões ou aulas sejam gravadas e disponibilizadas posteriormente (o item 3.2 .5 trata um pouco mais sobre a videoconferência).

\section{2 - ALGUNS RECURSOS}

Alguns recursos estão promovendo uma destacada contribuição e tendo um importante papel como elementos viabilizadores e aceleradores da utilização do computador na educação (e também no treinamento). A participação desses recursos vem crescendo rapidamente nas diversas áreas e atividades onde 0 
computador é utilizado, o que vem favorecendo a discussão em torno de seus potenciais educacionais.

Alguns deles estão descritos logo a seguir: CD-ROM, hipertexto, multimídia e hipermídia. Pela sua importância na disseminação da informação e pela sua transparência em trabalhar com vários recursos e serviços, também está descrita a rede mundial de computadores, a Internet.

\subsection{1 - CD-ROM}

O CD-ROM é um disco ótico para armazenagem de dados cuja sigla significa "Compact Disc - Read Only Memory", ou seja: seu conteúdo só pode ser lido (e não gravado) pelo usuário.

O CD-ROM é um disco rígido de plástico formado por uma camada de revestimento refletivo onde os dados são gravados. Sobre ela, existe uma camada protetora para preservar os dados (BADGETT \& SANDLER, 1994). Ele possui diâmetro de $120 \mathrm{~mm}$ e espessura de $1.2 \mathrm{~mm}$, com um buraco de $15 \mathrm{~mm}$ no centro para aceitar o eixo do drive.

A maioria dos CD-ROM's suporta aproximadamente 650MB de dados, enquanto que $\mathrm{C} C \mathrm{C}$ de áudio pode armazenar cerca de $680 \mathrm{MB}$, o suficiente para gravar 74 minutos de música. Essa menor capacidade de dados do CD-ROM se deve a códigos de correção que são embutidos junto com os dados originais, melhorando a integridade dos dados e permitindo que eles sejam reconstruídos quando existem resíduos de poeira e manchas na superfície do disco, ou mesmo quando a superfície está danificada.

Segundo BADGETT \& SANDLER (1994), na gravação dos dados em um CD-ROM, um raio laser queima os locais que irão armazenar um "1 lógico" e deixa em branco (sem queimar) os locais que irão armazenar um "0 lógico". O laser é controlado por dispositivos eletrônicos que traduzem os dados do computador em instruções "queimar/não queimar" e dizem ao laser onde os dados deverão ser colocados no disco. Em uma unidade de leitura de CD-ROM, o laser existente produz luz suficiente apenas para reconhecer os locais queimados para os dispositivos eletrônicos internos.

Algumas das vantagens do CD-ROM: 
- grande capacidade de armazenamento de dados;

- facilidade de partilhamento de dados com outros usuários;

- alta integridade dos dados;

- alta confiabilidade na detecção e correção de erros;

- durabilidade;

- taxas de transferência de dados crescentes;

- queda acentuada no preço.

Essas características fazem do CD-ROM um meio de armazenagem e distribuição de dados perfeito para uma série de atividades, incluindo bancos de dados, programas completos, aplicativos, produtos multimídia interativos, etc. Em muitas situações o CD-ROM é preferível à própria Internet, como é o caso da transmissão de grandes volumes de informação. Para LAUB (1986), o CD-ROM representa um novo meio de publicação, o centro de um novo gênero de aplicações para computador e uma poderosa ferramenta educacional.

Muitas empresas estão adotando o CD-ROM na confecção de catálogos de produtos, materiais de treinamento e suporte técnico, bem como na transmissão de base de dados corporativos e informações sobre vendas, ao invés de utilizar outras formas, como meios impressos ou Internet.

O número de jogos baseados em CD-ROM vem crescendo bastante, bem como o de aplicativos para escritório e revistas eletrônicas. As enciclopédias em CD-ROM já apresentam vendagens maiores que as impressas.

As vantagens dos discos óticos, incluindo a possibilidade de trabalhar com vários tipos de dados, como textos, figuras, arquivos de áudio e vídeo, entre outros, vem permitindo um crescimento enorme nos títulos de CD-ROM's educativos multimídia, que ensinam conceitos, estimulam a criatividade e incitam habilidades de crianças e adultos. Além dos títulos comerciais, muitas escolas e universidades estão desenvolvendo CD-ROM's multimídia para a educação de seus alunos.

A versatilidade do CD-ROM está eclipsando os atuais disquetes. Se antigamente as unidades de leitura eram vendidas com preços altos e como itens opcionais, hoje os microcomputadores já estão sendo oferecidos ao consumidor com as unidades para CD-ROM embutidas como itens de série, como o teclado e o monitor. 


\subsection{2 - HIPERTEXTO}

Com o aparecimento da escrita, o homem passou a utilizar o texto como o principal meio de representação do conhecimento. No texto tradicional, seja na forma impressa ou em arquivos de computador, a informação, os conceitos e idéias são apresentadas ao leitor em uma forma seqüencial. Segundo NIELSEN (1995), isso significa que existe uma única seqüência linear definindo a ordem que o texto deve ser lido. Ou seja: o leitor só pode avançar na leitura a um ponto que ainda não leu, ou retornar a um ponto que já foi lido. Para LIMA (1996), essa característica faz com que algumas relações não sejam representadas no conhecimento expresso através dos textos tradicionais, como é o caso das ligações existentes entre os conceitos mencionados em partes diferentes do texto.

O hipertexto veio para quebrar essa limitação. Segundo BELHOT (1997a), o hipertexto é uma solução tecnológica para organizar o acesso à informação. Para PIMENTEL (1989), o hipertexto organiza o armazenamento das informações de um documento, permitindo a realização de pesquisas não seqüenciais.

Em um documento hipertexto, não existe uma única opção que imponha a seqüência na qual o texto deve ser lido, já que o autor do documento deixa algumas alternativas para os leitores explorarem. Assim, o leitor pode escolher, no momento em que estiver lendo o texto, quais opções adotará na leitura (NIELSEN, 1995).

O hipertexto pode ser comparado aos textos tradicionais que possuem notas de rodapé: ao chegarem ao marcador da nota de rodapé (geralmente uma palavra destacada), os leitores devem escolher se continuam lendo o fluxo principal do texto ou se desviam para a nota de rodapé (NIELSEN, 1995). As enciclopédias, com suas inúmeras referências cruzadas, também são outra forma impressa com estrutura de acesso semelhante ao hipertexto.

Vannevar Bush é considerado o "avô" do hipertexto desde que propôs, em 1945, preocupado com a explosão da informação científica, o sistema Memex ("MEMory EXtender", que nunca foi realmente implementado), que seria um dispositivo mecânico no qual um indivíduo pudesse armazenar seus livros, registros, comunicações, bem como recuperar essas informações de forma rápida e flexível. Ted Nelson propôs em 1965 o sistema Xanadu e foi o primeiro a 
empregar a palavra "hipertexto" para descrever a visão de trechos de texto interligados (NIELSEN, 1995).

Em um sistema hipertexto, cada unidade de informação é chamada de nó. Os nós podem ter tamanhos variáveis, dependendo da necessidade ou propósito: assim, um nó pode ser desde uma tela de computador, um texto ou arquivo grande, até uma simples definição de um conceito. Basicamente, o tamanho do nó vai depender da natureza da informação contida no nó.

Cada nó pode conter referências para outros nós, permitindo que o leitor (ou usuário, já que se trata de um recurso computacional) "salte" de um nó para outro durante o processo de leitura. Essas referências entre as unidades de informação são chamadas de links (ou ligações). PINHEIRO, KOURY \& HUEBNER (1996) comparam o link a um marcador de livro que pode ser removido a cada instante.

NIELSEN (1995) explica que cada link conecta dois nós e é normalmente dirigido, o que significa que um link aponta de um nó (nó âncora) para outro (nó destino). Os links são muitas vezes associados a porções específicas dos nós conectados por eles, ao invés de ligarem os nós como um todo. Alguns nós estão relacionados a muitos outros nós, apresentando consequentemente muitos links, enquanto que outros servirão apenas como destinos de ligações, não tendo links para outros nós.

Assim, a estrutura completa de um hipertexto é formada por uma rede de nós interligados por meio de links. Evidentemente, a quantidade de nós existente na rede pode ser bastante variável, bem como a quantidade de links em cada nó. Quando se movimenta pela rede de nós e links, ao invés de uma simples leitura, o leitor realiza a chamada navegação. O programa utilizado para a visualização de documentos hipertexto é chamado de browser (ou navegador).

Em um nó, a presença de um link é indicada pela chamada âncora. A âncora indica e define os locais onde acontecem as ligações dentro dos nós (SANTOS, 1997). Assim, a âncora nada mais é do que uma representação visual do link, podendo ser uma palavra destacada ou algum tipo de mídia. Por exemplo, no caso da âncora ser uma palavra sublinhada, quando o leitor clica com o mouse sobre ela, ele "salta" para o nó destino ligado por aquele link.

De acordo com SANTOS (1997), a combinação dos três elementos, âncora, nó e link, produz mecanismos através dos quais os usuários conseguem obter 
acesso às informações armazenadas. Assim, a estrutura de criação desses três componentes tanto pode limitar quanto expandir os recursos a serem oferecidos ao sistema como um todo.

Ao contrário do texto tradicional, o hipertexto simula o processo de associação realizado pela mente humana, permitindo a movimentação pelos nós que contenham conceitos semelhantes ou relacionados. Assim, a navegação pelo hipertexto cria um processo mais parecido com o raciocínio humano, que não é linear.

A figura 5 representa uma estrutura simples de hipertexto, contendo 3 nós e 4 links. Cada palavra destacada acusa a presença de um link, que liga o nó atual a outro nó. Os documentos hipertexto podem ser organizados em diversos tipos de estruturas, dependendo das ligações existentes.

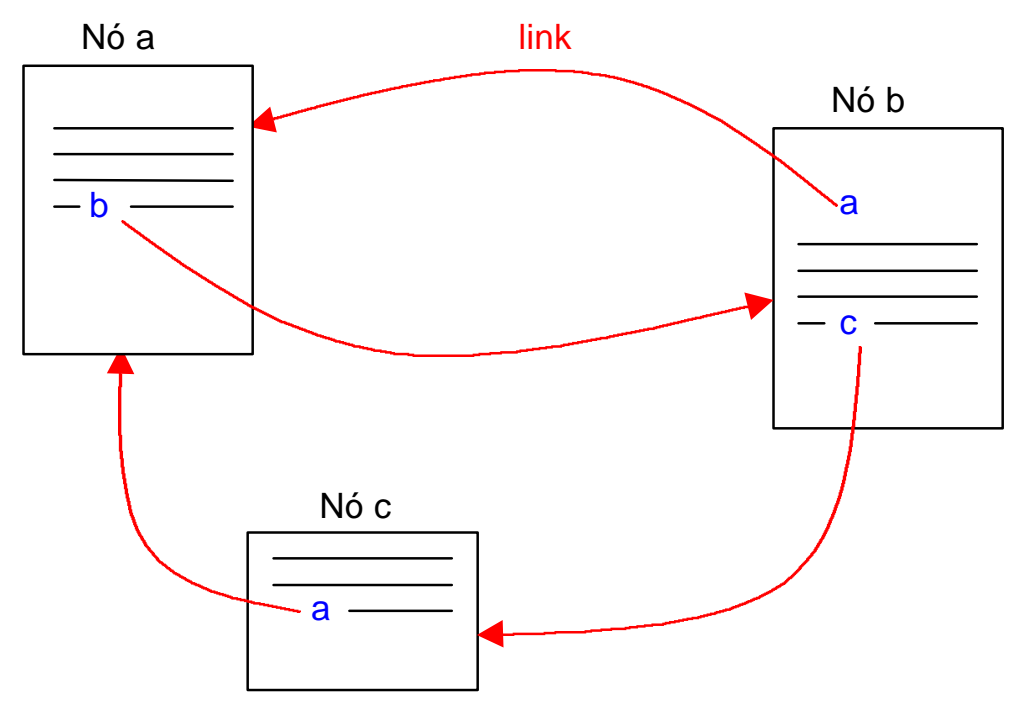

FIGURA 5 - Uma estrutura simples de hipertexto

O hipertexto é utilizado em um grande número de aplicações. NIELSEN (1995) divide essas aplicações em cinco grupos:

- Aplicações computacionais: documentação on-line, ajuda ao usuário, engenharia de software, sistemas operacionais;

- Aplicações comerciais: restauração e outros manuais, dicionários e livros de referência, auditoria, leis, shows comerciais, catálogos de produtos; 
- Aplicações intelectuais: apoio à organização de idéias e "brainstorm", jornalismo, pesquisa;

- Aplicações educacionais: língua estrangeira, clássicos, museus;

- Aplicações para passatempo e lazer: guias turísticos, bibliotecas, ficção interativa, notícias, jornais e revistas.

SHNEIDERMAN (1989) propôs três regras que devem ser satisfeitas para determinar se uma aplicação é adequada para a utilização do hipertexto:

1. Uma grande massa de informação é organizada em numerosos fragmentos;

2. Os fragmentos estão relacionados entre si;

3. O usuário precisa apenas de uma pequena fração a cada momento.

O hipertexto é hoje uma ferramenta quase obrigatória no desenvolvimento de softwares educativos. Sua estrutura permite que o aluno navegue pelos documentos atrás da informação desejada, movimentando-se de forma não linear e tendo sua pesquisa enriquecida pela presença dos links, que criam ligações entre os conceitos relacionados, o que favorece o processamento da informação. Para NIELSEN (1995), o hipertexto é bastante adequado para aplicações abertas de aprendizagem em que o aluno tem liberdade de ação e é encorajado a tomar a iniciativa.

Na busca da informação através da movimentação pelos nós, o usuárioaluno tem o poder da decisão, tendo liberdade e responsabilidade pela escolha dos caminhos possíveis a serem seguidos na rede. "O usuário é livre para explorar qualquer seqüência de informação no documento. Assim, em vez de seguir a seqüência explícita do documento, o usuário pode escolher explorar uma árvore de alternativas contextuais" (PINHEIRO, KOURY \& HUEBNER, 1996, p.757). Segundo AFONSO, DIAS \& MAIA (1998), o caminho que o usuário escolher estará baseado, em grande parte, em suas necessidades, experiência e conhecimento prévio.

Existem muitas críticas sobre conceder "liberdade total" de navegação ao aluno, já que existem poucas evidências que mostrem uma contribuição educacional relevante nesse tipo de controle do usuário (ver SANTOS, 1997 e 
FREIRE, 1998). Assim, muitos sistemas hipertexto fazem com que o aluno seja guiado ou orientado durante a navegação, através do fornecimento de roteiros prontos. A questão do controle do usuário sobre o sistema será discutida com mais detalhes no item 4.1.2.

Há pelo menos dois problemas bem conhecidos relacionados aos sistemas hipertexto: a desorientação e a sobrecarga cognitiva, que estão explicitados logo a seguir:

\section{Desorientação}

Segundo CONKLIN (1987), a desorientação refere-se à tendência do usuário perder o senso de direção e localização em um documento não linear: ou seja, em redes grandes e complexas o usuário muitas vezes não sabe em que ponto da rede está ou como ir para um outro ponto da rede que ele sabe (ou acha) que existe.

\section{Sobrecarga cognitiva}

O autor de documentos hipertexto, além de dedicar preocupação ao conteúdo do documento, tem ainda que planejar e incluir nós e ligações à rede, sendo que para isso ele deverá prever o que o usuário irá fazer quando estiver navegando pelos documentos. Por sua vez, o usuário é apresentado a um grande número de nós e links durante a navegação, devendo tomar uma série de decisões sobre quais visitar e quais ignorar (CONKLIN, 1987).

Essas tarefas, necessárias em ambientes hipertexto, geram uma sobrecarga cognitiva no autor e no usuário, exigindo esforço e concentração adicionais.

Esses problemas podem ser contornados através de melhorias no projeto de interface e performance do sistema, bem como através de pesquisas sobre técnicas de filtragem de informações (CONKLIN, 1987). Pela relação existente entre o controle do usuário sobre o sistema e a desorientação e a sobrecarga cognitiva, o fornecimento de roteiros prontos ao usuário, de modo que ele siga por um caminho pré-determinado, também pode ser uma solução. 


\subsection{3 - MULTIMÍDIA}

O mundo e todos os seres que nele habitam utilizam meios variados de expressão: cores, sons, imagens, gestos, desenhos e movimentos são algumas das formas utilizadas como meio de comunicação - não só pelo homem, mas pelos animais, pela imprensa, pela televisão e cinema, pelos livros, pela arte, pelo cotidiano das ruas. Para NASCIMENTO \& BASTOS (1996), multimídia significa a combinação das diversas formas de comunicação.

O desenvolvimento dos computadores atuais, consubstanciado por novos equipamentos de hardware e software, possibilitou a introdução da multimídia no mundo da informática, permitindo transformar o computador - outrora uma máquina cuja interface se expressava basicamente por meio de caracteres desenhados na tela - em uma máquina com uma comunicação muito mais próxima do mundo real - um mundo multimídia por natureza.

$\mathrm{Na}$ informática, multimídia é o termo utilizado para representar o uso simultâneo de dados que estão em diferentes formatos: imagem, texto, animação, vídeo, som, entre outros, conforme ilustrado na figura 6 . Assim, a multimídia é uma forma de armazenar e recuperar a informação por meio do computador. De acordo com BOARETTO Jr. (1996), a multimídia está sendo considerada uma das maiores transformações tecnológicas na computação dos últimos tempos.

Por tornar a interface com o usuário muito mais amigável, a multimídia começa a ganhar cada vez mais espaço nos softwares comerciais, aplicativos e jogos eletrônicos. Além disso, muitas empresas estão passando a utilizar a multimídia na produção de CD-ROM's com catálogos de seus produtos, permitindo não apenas mostrar especificações textuais, mas também fotos, animações, vídeos e descrições sonoras do produto.

Quiosques de informações que usam a multimídia são cada vez mais comuns em museus, shopping centers, grandes lojas, supermercados e outros locais de grande circulação de pessoas. Até os terminais bancários estão agregando novas mídias para facilitar o contato com o cliente. REIS, GRIMONI \& FADIGAS (1996) comentam sobre a explosão, nos últimos anos, dos títulos de produtos multimídia baseados em CD-ROM, principalmente aqueles voltados para o ensino informacional (como atlas e enciclopédias), entretenimento (jogos) e divulgação cultural (como música e arte). 


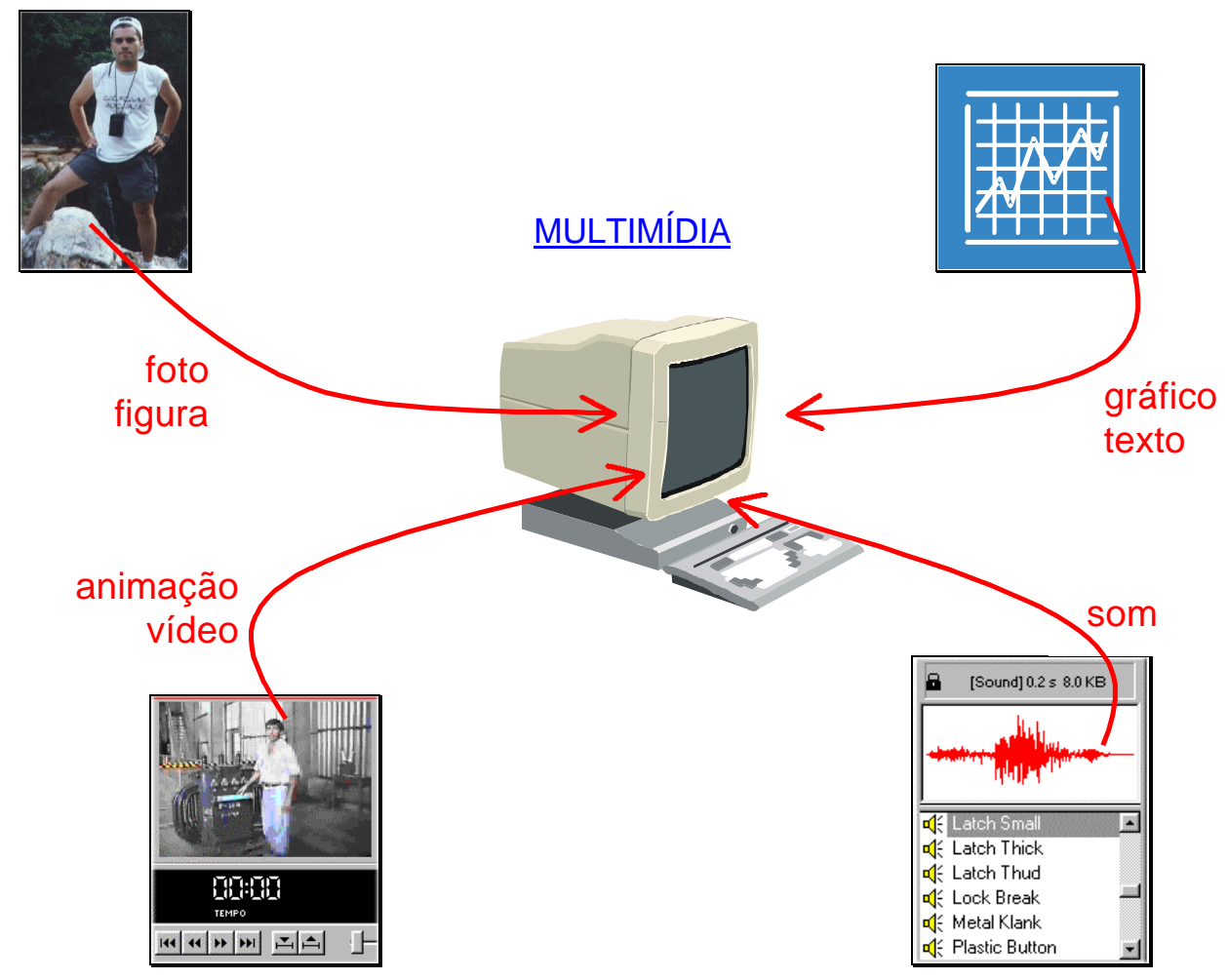

FIGURA 6 - Multimídia: informação em diferentes formatos

Quando comparada com as mídias tradicionais como televisão, jornal, livro e revista, além de agrupar a informação em um número maior de formatos, a multimídia via computador possibilita pelo menos outras duas vantagens: a primeira é permitir a interatividade (capacidade que o programa tem de responder a estímulos e ações do usuário: clicando com o mouse ou digitando uma tecla, o programa reage, abrindo uma janela ou mostrando um vídeo; PEREIRA, 1999, explica que a interatividade digital pode ser compreendida como uma espécie de "diálogo" entre homens e máquinas), e a segunda é sua capacidade de atuar em harmonia com o hipertexto, possibilitando que informações com diferentes formatos sejam acessadas de forma não linear (no contexto dessa segunda vantagem, a multimídia passa a se chamar hipermídia, descrita no próximo item).

Essas duas vantagens são especialmente interessantes para uma área onde a multimídia já é considerada uma importante ferramenta: a educação. MASUERO \& GONZÁLEZ (1998) defendem que uma ferramenta multimídia bem empregada pode ser superior aos recursos visuais de explanação tradicionalmente empregados em sala de aula. 
Segundo PEREIRA (1999), a multimídia possibilita uma "linguagem lúdica", onde o ato de divertir está intimamente vinculado à atividade de informar e educar. Para LIMA (1996), o fato de melhorar o interesse e a atenção do aluno faz com que a multimídia promova uma melhor retenção da informação.

NASCIMENTO \& BASTOS (1996, p.427) comentam que a multimídia como forma dinâmica de comunicação mistura "o aspecto interativo do computador, o poder audiovisual da televisão e a abrangência de publicação e divulgação em massa da imprensa escrita. É um poderoso método de comunicação, que possibilita ao professor atingir seus objetivos junto aos alunos, de uma maneira atrativa e eficaz, despertando maior interesse e motivação". Os autores defendem que através da incorporação da multimídia na educação poderão ser encontradas melhores soluções para:

- a melhoria do rendimento e da produtividade do processo de ensinoaprendizagem;

- o aumento do grau de satisfação do aluno;

- a melhoria dos sistemas de avaliação;

- o enriquecimento do conteúdo didático.

A multimídia é um recurso que parece ter uma vocação natural para a educação. Sua introdução no ambiente escolar vem transformando as formas de aquisição do conhecimento. Uma interface multimídia bem projetada pode enriquecer o ambiente de aprendizagem e permitir que o aluno participe da construção do seu conhecimento. $\mathrm{Na}$ interatividade, o objeto interativo gera um diálogo com o aluno.

Cada mídia é mais adequada para transmitir um tipo de informação. Assim, como a multimídia trabalha com um conjunto delas, há uma sinergia no sentido de que uma mídia complementa a outra no processo de transmissão da informação, influindo no aspecto cognitivo do usuário por permitir que mais sentidos sejam ativados durante o processo de aprendizagem.

As vantagens da multimídia estão incentivando o desenvolvimento de sistemas ou aplicações multimídia voltados para o ensino e o treinamento. Essa tendência favorece a disseminação no mercado dos chamados softwares de autoria. 
Existem softwares específicos para cada tipo de mídia, como o ADOBE Photoshop e o Corel DRAW para a criação de imagens, o Macromedia FLASH para animações, o ADOBE Premiere para vídeo. A finalidade do software de autoria é reunir todas as mídias criadas por esses (ou outros) softwares e gerar a aplicação final, permitindo sua distribuição por meio de CD-ROM ou via rede, por exemplo. Entre os softwares de autoria disponíveis no mercado, estão: o ToolBook da Asymetrix, o Authorware e o Director, ambos da Macromedia.

Alguns dos softwares de autoria possuem interface com a Internet, gerando arquivos HTML (ver item 3.2.5). Se a disponibilização da aplicação na rede for uma escolha prioritária, uma outra opção é desenvolvê-la diretamente na linguagem HTML, que possui bons recursos multimídia, especialmente se for utilizada em conjunto com outras linguagens, como a Java (da Sun Microsystems).

O grande problema ainda é a velocidade da Internet - extremamente baixa para trabalhar com recursos multimídia, especialmente em linhas discadas de usuários comuns. Esse problema afeta principalmente as chamadas mídias temporais, como áudio e vídeo, que geram enorme volume de dados na rede.

Um outro problema relacionado à utilização da multimídia refere-se ao custo dos equipamentos de hardware e software, ainda altos para os padrões de muitas instituições de ensino (CELINSKI, 1998). Além disso, sistemas multimídia exigem um longo tempo de desenvolvimento e têm um elevado custo de produção. No entanto, segundo NASCIMENTO \& BASTOS (1996), por permitirem sua utilização repetidas vezes, as soluções multimídia podem reduzir os custos das aulas de laboratório por simularem as experiências, evitando a repetição de montagens e a utilização e manuseio dos caros equipamentos reais. Também pode haver troca de cursos entre as instituições, evitando a duplicidade de esforços.

Muitas empresas já estão utilizando a multimídia como forma de reduzir seus custos de treinamento, através da utilização de programas de instrução interativos via computador. REIS, GRIMONI \& FADIGAS (1996) comentam que cursos em ambiente multimídia podem ser aplicados "in the job", evitando o deslocamento do funcionário para um local externo e a manutenção de uma estrutura de treinamento dentro da empresa, o que no final acaba acarretando custos mais baratos e competitivos comparados aos cursos convencionais. 


\subsection{4 - HIPERMÍDIA}

O termo hipermídia representa uma extensão do conceito de hipertexto: refere-se à associação do hipertexto com a multimídia. Assim, um sistema hipermídia é aquele que permite criar uma rede de nós interligados por links, onde os nós podem conter diferentes tipos de informações: além de textos, podem conter figuras, animações, vídeos, gráficos, etc.

No contexto da hipermídia, uma figura ou um arquivo de áudio ou vídeo pode ser o próprio nó, que é interligado a qualquer outro nó (por exemplo, um nó responsável por "chamar" a mídia) por meio de um link. Além disso, a âncora representativa do link pode estar em um formato visual diferente do textual, como uma figura ou gráfico.

Para DUCHASTEL (1990), a hipermídia é uma tecnologia com potencial para melhorar radicalmente a interação do homem com a informação. Segundo FREIRE (1998), a utilização da hipermídia em ambientes de ensino oferece uma maior flexibilidade de uso e uma melhor apresentação das informações aos usuários. Além disso, devido aos recursos audiovisuais normalmente disponíveis, ela também estimula os alunos a aprender.

De acordo com LACERDA \& MACHADO (1996), os sistemas hipermídia têm um potencial fantástico em termos de comunicação, direcionando todo o processo de concepção e produção de softwares utilizados para fins educacionais. No entanto, para conceber e desenvolver um documento hipermídia é preciso conhecer, além das características dos diferentes formatos de representação da informação (texto, vídeo, som ou imagem estática), a forma mais adequada de trabalhar com esses formatos conjuntamente.

Por ser uma extensão do hipertexto, a hipermídia é utilizada nos mesmos tipos de aplicações, apresenta as mesmas características e, consequentemente, tem as mesmas vantagens e desvantagens. Assim, deve haver preocupação com a desorientação e a sobrecarga cognitiva, além de um cuidado especial no projeto do controle do usuário sobre o sistema. Pelo lado da multimídia, as desvantagens da hipermídia referem-se à exigência de equipamentos de software e hardware especiais, bem como os altos custos e longo tempo para desenvolver os sistemas.

O sistema hipermídia mais conhecido e utilizado atualmente é a Web (ver item 3.2.5). Nela documentos hipermídia estão distribuídos por computadores em 
todo o mundo, criando uma rede quase infinita de nós com informações em diferentes formatos, interligados por meio de links. A figura 7 mostra uma página (documento hipermídia) da Web.

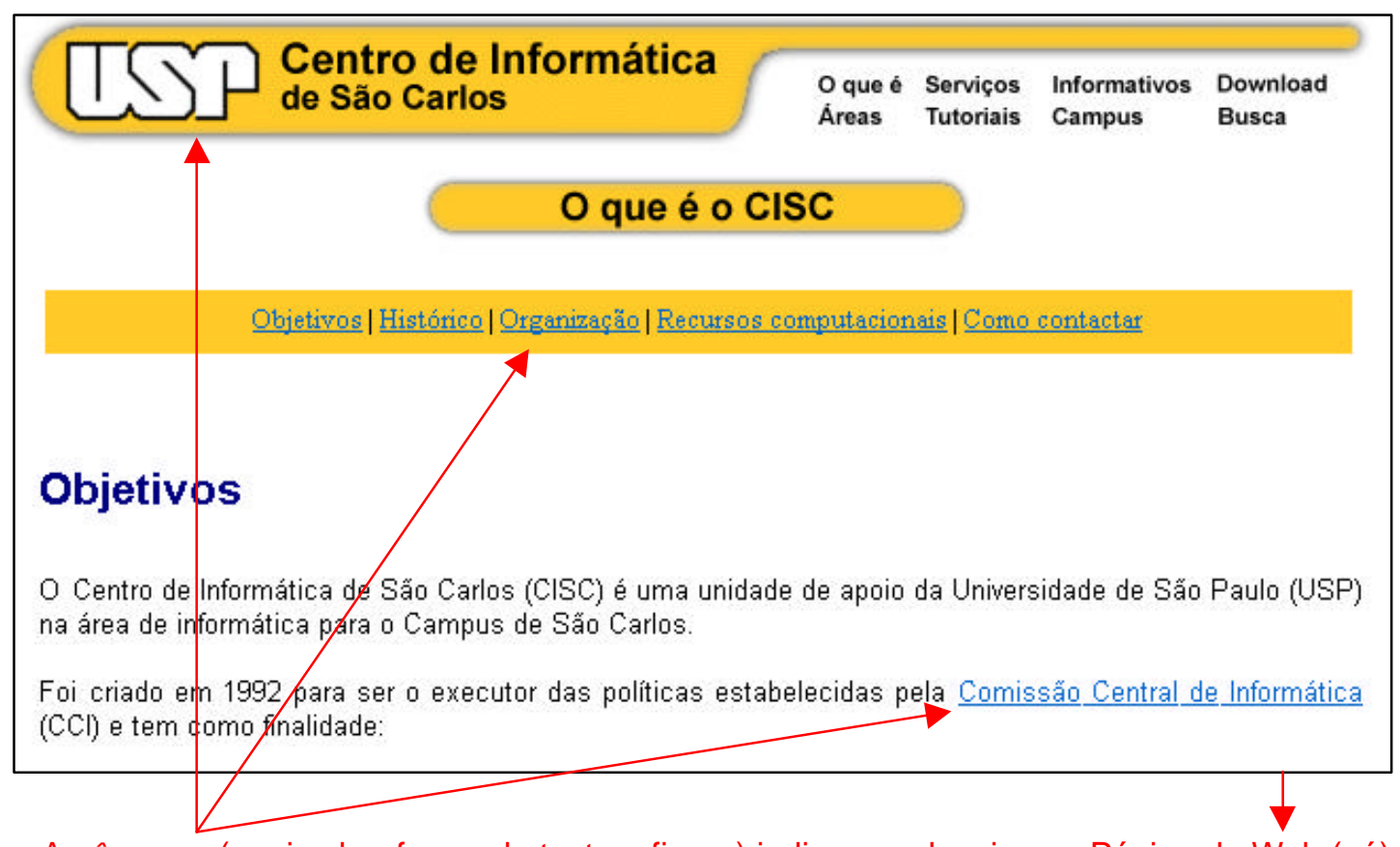

As âncoras (aqui sob a forma de texto e figura) indicam os locais Página da Web (nó) onde existem links para outros documentos (nós)

FIGURA 7 - A Web: sistema hipermídia

$\mathrm{Na}$ navegação por documentos hipermídia é muito comum o usuário, estando em um determinado nó, precisar voltar a um ou mais nós já visitados. Se o nó que ele se encontra no momento não possuir links para esses nós, ele pode utilizar o recurso de backtrack, comum em muitos sistemas hipertexto/hipermídia, que permite voltar aos nós já visitados (os navegadores costumam implementar esse recurso em um botão chamado "voltar" ou "back").

Muitos autores utilizam os termos hipertexto e hipermídia indistintamente, alegando não existir nenhuma razão para reservar dois termos diferentes para os dois tipos de sistemas (ver por exemplo NIELSEN, 1995, que utiliza apenas o termo hipertexto). SANTOS (1995), por outro lado, utiliza multimídia como sinônimo para hipertexto e hipermídia. Assim, não deve ser motivo de espanto encontrar termos mesclados ou gerais em uma pesquisa sobre o assunto. 


\subsection{5 - INTERNET}

A Internet é uma dessas invenções que transformam o mundo, mudando padrões de comunicação, de acesso a serviços e informação, de pesquisa e de relacionamento interpessoal.

\section{HISTÓRICO}

De acordo com RANGEL (1996a e 1996b), a fagulha que iniciou o processo que culminou na criação da Internet começou em 1957, quando a exUnião Soviética (URSS) colocou em órbita o primeiro satélite espacial - o Sputnik. Quatro meses depois o presidente americano Dwight Eisenhower anunciava a criação da ARPA ("Advanced Research Projects Agency"), para pesquisar e desenvolver alta tecnologia para as forças armadas.

Em 1962 a ARPA incumbiu a RAND Corporation - um conselho formado em 1948 - de criar um método que garantisse as comunicações governamentais, em caso de um ataque nuclear da URSS. Em 1964 a RAND publicou o relatório "On Distributed Communication", sobre redes de comutação de pacotes. O conceito de comutação de pacotes evitava o modelo centralizado, prevendo que os nós da rede seriam interligados por caminhos redundantes e teriam autonomia para gerar, transmitir e receber mensagens. O objetivo era garantir que os pacotes (pequenos grupos de dados) chagassem ao seu destino, sendo o caminho utilizado irrelevante. Em 1967 a ARPA apresentou o primeiro plano real de uma rede desse tipo.

Em 1968, a ARPA convocou quatro universidades americanas para iniciar a implementação da rede de pacotes, que receberia o nome de ARPANET. Antes do fim de 1969 as quatro universidades já estavam conectadas através de um equipamento chamado "Interface Message Processor", da empresa BBS (a mesma que inventou o modem, em 1963), e através do protocolo NCP ("Network Control Protocol").

A ARPANET começou a se estender a outras instituições, crescendo rapidamente com o passar dos anos. Um novo protocolo, o TCP/IP ("Transmission Control Protocol/Internet Protocol"), foi proposto. O TCP era responsável por quebrar as mensagens em pacotes de um lado e recompô-las do outro, enquanto que ao IP cabia descobrir o caminho adequado entre o remetente e o destinatário, 
além de enviar os pacotes. Esse novo protocolo foi adotado progressivamente, funcionando junto com o NCP até 1983. Após essa data o TCP/IP passou a funcionar sozinho.

A partir de 1984, um órgão independente do governo americano chamado National Science Fundation (NSF), passou a ser responsável pela manutenção da ARPANET. Em 1986, a NSF decidiu criar cinco centros de supercomputação com o objetivo de aumentar a largura de banda disponível. Esses centros receberam o nome de NSFNET e foram conectados a $56 \mathrm{Kbps}$ (Kilo bits por segundo, que é uma medida da velocidade de transmissão de dados), passando a ser conhecidos como o backbone (trecho de maior capacidade da rede, que tem o objetivo de conectar várias redes) da ARPANET.

A criação da NSFNET serviu como incentivo para a adesão de outras redes e, entre os meses de fevereiro e novembro, o número de hosts (computadores ligados permanentemente à rede, que armazenam arquivos e permitem o acesso de usuários) pulou de dois para cinco mil. Nessa época já era possível o acesso direto à rede via modem através do protocolo SLIP ("Serial Line Internet Protocol"), que implementava o protocolo IP em linhas discadas.

Em 1987, a NSF contratou a Merit Network Inc. que, junto com a IBM e a $\mathrm{MCl}$, forneceu a primeira conexão T1 (de $1.544 \mathrm{Mbps}$ ). Um ano depois todo o backbone da NSFNET foi atualizado para canais T1. O número de máquinas online já chegava a cem mil.

Em 1990, depois de dividida em MILNET, para organismos militares, e em NSFNET, para pesquisadores, a ARPANET foi formalmente encerrada. Por sugestão da Merit, a NSFNET passou a englobar também empresas. Assim, a Internet nasce compreendendo 1.500 sub-redes e 250 mil hosts. Depois de aberta ao grande público, a rede passa a crescer a taxas exponenciais. O primeiro provedor de acesso comercial do mundo, o World, entrou em operação ainda em 1990.

Em 1992 começam a ocorrer as primeiras tentativas de fazer broadcast (envio de uma mesma mensagem para diversos usuários) na rede, algo que não era previsto na especificação inicial do TCP/IP. O governo americano, estimulado pelo vice-presidente Al Gore, reconhece a importância da infra-estrutura de comunicação e promulga a Lei de Infra-estrutura Nacional de Informação.

Com o passar dos anos novas tecnologias foram desenvolvidas, como a 
linguagem de programação Java e o VRML ("Virtual Reality Modeling Language"), e muitas empresas começam a se reestruturar para tomar parte do fenômeno Internet.

Em 1996 o presidente americano Bill Clinton sanciona a nova Lei de Telecomunicações, que libera o setor por completo, iniciando a competição pelos mercados de telefonia local e de longa distância, TV a cabo e satélite (maiores informações sobre o assunto podem ser obtidas em RANGEL, 1996a e 1996b).

\section{NO BRASIL}

Segundo VILLAS \& CAMPOS (1994), no Brasil já existiam conexões internacionais de redes não comerciais com o exterior em 1988. Na época, a única tecnologia implementada era a BITNET ("Because It's Time NETwork", chamada originalmente de "Because It's There NETwork" - rede acadêmica criada em 1980 e que interligava a City University de Nova York e a Universidade de Yale).

De acordo com esses autores, em 1990 decidiu-se pela implantação de uma Rede Nacional de Pesquisa (RNP), coordenada pelo CNPq ("Conselho Nacional de Desenvolvimento Científico e Tecnológico"), e recomendada a adoção do TCP/IP. Entretanto, o backbone da RNP foi instalado somente em 1992, contemplando as principais universidades do país, organizações governamentais, não-governamentais e de pesquisa.

Segundo GARCIA (1997), a exploração comercial da Internet iniciou-se em dezembro de 1994, a partir de um projeto piloto da Embratel ("Empresa Brasileira de Telecomunicações", estatal na época).

\section{INTERNET HOJE}

Estendendo qualquer análise que simplesmente a intitule como uma rede de computadores interligados pelo mundo inteiro, a Internet avança como o maior e mais democrático canal de disseminação da informação do nosso tempo, como a plataforma que potencializa e incentiva o trabalho cooperativo, como a vitrine global do marketing moderno, como a máquina do tempo que quebra a limitação espacial-temporal e como a sala mundial do relacionamento interpessoal.

A rede cresce a uma velocidade espantosa. Isso pode ser notado inclusive em alguns países orientais mais ortodoxos, cujas culturas fechadas geram uma 
contradição, considerando que a rede exige de seus usuários um comportamento aberto para o mundo e uma (nova) cultura baseada na "Era da Informação".

A rede também quebra padrões e valores. Uma amizade não depende mais da presença física ou de um rosto, o comércio de um produto não exige mais a locomoção, as artes já podem ser apreciadas dentro de casa. Evidentemente, considerando seu tempo de existência, ainda não se pode analisar com clareza e propriedade todas as conseqüências que seu avanço irá trazer. No entanto, seria omissão não acreditar em seu potencial como veículo contribuinte do progresso da humanidade.

Além da área comercial e de entretenimento, a Internet está explodindo também na educação. Segundo GARCIA (1997), a rede pode ser considerada a mais completa, abrangente e complexa ferramenta de aprendizagem do mundo. Para GOMES (1998), sua utilização pedagógica é um desafio que professores e escolas deverão enfrentar, pois ela representa uma concepção socializadora de informações. Para a autora, apesar dos computadores usualmente serem vistos como máquinas frias que não possibilitam o contato humano, as redes eletrônicas estão permitindo a emergência de novas maneiras de conceber as relações sociais. Os benefícios da utilização das redes estão diretamente relacionados às novas formas de aprendizagem em que a interação, o acesso ilimitado às informações, a questão multidisciplinar e colaborativa se unem para redimensionar os modelos educacionais.

REIS, GRIMONI \& FADIGAS (1996) comentam que a utilização da Internet como meio de comunicação que possibilita a troca de programas, imagens e textos permitiu democratizar a informação. Para esses autores, o ponto mais positivo da Internet é justamente a possibilidade de troca de informações a nível mundial entre grupos ou pessoas isoladas com interesses comuns.

Segundo HÖLBIG et al. (1998), pela Internet busca-se facilitar e agilizar a crescente demanda pelo saber. A rede pode alcançar um grande número de pessoas e grupos, se adapta ao ritmo de cada um e a sua versatilidade favorece a aprendizagem, na medida em que não exige deslocamentos do local de trabalho ou de casa.

Em atividades de ensino-aprendizagem, é possível afirmar que a Internet já se tornou indispensável: universidades virtuais, cursos completos e aulas on-line, tutoriais, publicações científicas e artigos crescem a cada dia na rede. A Internet 
tem proporcionado novos meios de ensino-aprendizagem como alternativa aos tradicionais. Sua flexibilidade facilita a publicação e a atualização da informação. Aliada tanto dos usuários mais comuns como de toda a comunidade científica, a rede democratizou o conhecimento e definitivamente tornou-o patrimônio de toda a humanidade.

Através da Internet o aluno pode assumir uma postura ativa diante da aprendizagem: interagindo, comunicando e filtrando a informação. Para GOMES (1998), a Internet oferece vários tipos de aplicações educacionais: divulgação dos trabalhos de escolas, professores e alunos; pesquisa individual ou em grupo, dentro ou fora do ambiente de aula; comunicação entre os alunos e entre alunos e professores.

PINHEIRO, KOURY \& MEDEIROS (1997, p.1167) defendem que os recursos da Internet "não são um mero símbolo de sofisticação tecnológica, com resultados práticos duvidosos. Eles podem ser efetivamente um instrumento transformador do ensino acadêmico". Para esses autores, a Internet pode ajudar os alunos em atividades do tipo:

- pesquisa bibliográfica: pela rede a informação é atualizada de forma mais rápida que em qualquer publicação impressa;

- visitas virtuais: a rede possibilita um passeio virtual por universidades, laboratórios, indústrias, museus, etc;

- interligação on-line: por exemplo, com outras escolas, o que estimula o trabalho cooperativo e a troca de informações entre os alunos;

- educação a distância: são cada vez mais comuns os cursos de extensão e atualização pela rede.

A Internet está derrubando as paredes das escolas e abrindo as fronteiras do conhecimento, permitindo que o aluno saia do seu isolamento, tome decisões e participe da aprendizagem com seus professores e colegas. Segundo GOMES (1998), os professores têm na Internet um ambiente interativo, moderno, desafiador e inovador, permitindo transformar o processo de ensino-aprendizagem em uma aventura dinâmica, inovadora e com um poder de comunicação inusitado. Pela rede o professor pode estar mais próximo do aluno, recebendo mensagens e repassando informações, seja da escola ou de casa. 


\section{ACESSO}

O aumento exponencial no número de usuários vem provocando problemas de acesso à Internet, principalmente nos países menos desenvolvidos, onde a infra-estrutura é precária e os investimentos escassos.

Tecnologias de acesso mais eficientes que a linha telefônica estão sendo desenvolvidas, objetivando melhorar o fluxo de dados pela rede. Entre essas novas tecnologias está o acesso via cabo ou via satélite. Outra tecnologia que merece destaque é a Internet2: uma rede de alta velocidade que visa inicialmente o desenvolvimento de aplicações tais como a telemedicina, laboratórios virtuais, bibliotecas digitais, entre outras que não são viáveis com a tecnologia da Internet atual.

\section{INTERNET: SERVIÇOS}

A Internet possui um grande número de serviços, utilizados para diversas finalidades. Os serviços utilizam o modelo cliente-servidor: a execução do serviço é concentrada em programas-servidores, que por sua vez são acessados pelos usuários via programas-clientes.

A seguir estão descritos os principais serviços da rede. Alguns deles estão caindo em desuso, sendo gradativamente substituídos por outros, principalmente pela Web. Porém, pelo objetivo informativo, parece válido descrever, ainda que de forma breve, serviços que já foram muito utilizados e que, por isso, merecem ser conhecidos.

\section{Correio eletrônico (E-main)}

É o serviço de troca de mensagens (eletrônicas) entre os usuários da rede. $\mathrm{O}$ e-mail permite que arquivos sejam enviados junto com a mensagem (os chamados arquivos atachados ou anexos).

De modo geral, o endereço eletrônico é formado por um nome ou pseudônimo do usuário, seguido do símbolo @ (arroba, que significa em), da sigla da instituição responsável pelo acesso, do tipo de instituição (com para instituições privadas, gov para governo, edu para instituições educacionais, org 
para outras instituições, etc) e do domínio global do país (sigla do país). Exemplo: exemplo@uol.com.br.

Para GARCIA (1997), o correio eletrônico como ferramenta educacional pode ser utilizado para a troca de mensagens entre os alunos, entre os alunos e o professor, entre escolas e também em projetos educacionais e cursos a distância.

\section{Listas de discussão (Mailing lists)}

É um banco de dados com endereços eletrônicos de pessoas que estão interessadas em discutir algum assunto em particular. Quando uma mensagem é enviada à lista, ela é repassada a todas as pessoas participantes, por meio de seus endereços. As listas podem ser criadas por qualquer pessoa e envolver qualquer tema.

As listas são divididas em moderadas e não-moderadas: nas moderadas existe um responsável pela lista, que lê as mensagens com o objetivo de verificar se o foco das discussões está sendo respeitado, enquanto que nas nãomoderadas as mensagens são repassadas aos participantes automaticamente e sem um controle.

Sobre a aplicação desse serviço no ambiente de ensino, GARCIA (1997) comenta que podem ser criadas listas educacionais de diferentes assuntos e áreas do conhecimento. Essas listas podem gerar debates entre grupos de alunos e professores que têm interesses em comum.

\section{Usenet}

É uma rede que abriga grupos de discussão (os chamados newsgroups ou groups). Segundo RANGEL (1996a), ela foi criada inicialmente com o objetivo de distribuir informações a pessoas da comunidade Unix (seu nome, aliás, significa "Unix User Network"). Seu crescimento foi bastante rápido e como os grupos de discussão multiplicaram-se, foi necessário agrupá-los em diferentes categorias. Atualmente ela é formada por milhares de grupos de discussão criados para discutir sobre os temas mais diversos.

REGISTRO (1999) explica que as discussões acontecem através de troca de mensagens, que são enviadas e armazenadas por assunto em determinados computadores da rede, os chamados news servers (a rede formada pelos news 
servers é que recebe a denominação de Usenet), que são mantidos por agências governamentais, instituições educativas, empresas e usuários. As mensagens ficam disponíveis a todos os interessados que quiserem ler ou fazer uma cópia delas.

Segundo KEHOE (1993), assim como as listas de discussões, alguns newsgroups exigem que suas discussões permaneçam focalizadas; para atender a esta necessidade, surgiram os grupos moderados. Todos os artigos enviados para um grupo moderado são enviados ao seu moderador, que, periodicamente, revê as mensagens e, então, ou as envia individualmente para a Usenet, ou encaminha um sumário composto dos artigos dos últimos dias".

\section{$\underline{\text { Telnet }}$}

É o principal protocolo da Internet para estabelecer conexão com uma máquina remota (KEHOE, 1993). De acordo com GOMES (1998), através de um programa cliente telnet o usuário seleciona o computador (remoto) onde deseja executar uma aplicação qualquer. Nesse computador é acionado um servidor telnet. Para o estabelecimento da sessão, normalmente são solicitados um login (nome ou identificação do usuário) e uma senha. Uma vez estabelecida a sessão, o usuário pode executar qualquer aplicação que esteja autorizada para essa sessão.

\section{FTP}

O FTP ("File Transfer Protocol”) é o serviço padrão para transferência de arquivos entre computadores da Internet. Através dele o usuário pode enviar arquivos do seu computador para outro, ou descarregar no seu computador arquivos de um computador que esteja localizado em outro ponto da rede. Em muitos sistemas, FTP também é o nome do software que implementa o protocolo (KEHOE, 1993).

GOMES (1998) explica que em uma sessão FTP o usuário pode pesquisar a estrutura de diretórios e arquivos do equipamento remoto, antes de realizar a transferência. São comuns os locais da Internet que oferecerem acesso do tipo anonymous FTP (FTP anônimo), o que significa que a sessão permite ao usuário o acesso aos diretórios e arquivos do equipamento remoto sem exigir login ou senha de acesso. 
Através do FTP, alunos e professores podem ter acesso a programas freeware (software distribuído gratuitamente) e shareware (softwares que podem ser experimentados antes da compra), além de bancos de dados de imagens, textos, artigos, livros, músicas, etc.

\section{Gopher}

O Gopher é um serviço de busca que permite ao usuário navegar pela rede procurando uma dada informação (um artigo, um texto, uma imagem, etc) através de menus. Foi criado em 1991 na Universidade de Minnesota (RANGEL, 1996b).

No Gopher o usuário busca a informação desejada por meio de uma árvore de menus. Cada item de um menu pode ser um arquivo de informações, um programa a ser executado ou simplesmente um item que leva a outro menu. Cada item pode estar em um ponto diferente da rede.

De acordo com GOMES (1998), a cada novo item de menu selecionado corresponde uma interação com o servidor Gopher do equipamento onde reside o item. Quando alcança a informação procurada, o usuário pode simplesmente visualizar ou transferir o arquivo. O Gopher possui o recurso de marcador de páginas (bookmark), que permite a criação de uma lista contendo os itens de menus mais acessados pelo usuário, de modo que ele não precise percorrer toda a árvore de menus quando quiser atingir o item novamente.

Um problema do Gopher é que o usuário tem que navegar pela árvore de menus para encontrar a informação desejada. Assim, se ele não tem idéia onde a informação possa estar, sua pesquisa pode ficar complexa. O programa Veronica, desenvolvido em 1992 na Universidade de Nevada, contorna esse problema.

GILSTER (1995) esclarece que através de uma palavra-chave fornecida pelo usuário, o Veronica percorre todo o "gopherespaço" e, através de um banco de dados que ele próprio mantém, apresenta os resultados de sua pesquisa sob a forma de um menu Gopher. O usuário pode então escolher qualquer item do menu como se fosse um item Gopher. O banco de dados é atualizado periodicamente por um servidor Veronica, que consulta servidores Gopher que ele conhece e solicita seus menus. 
WAIS

O WAIS ("Wide Area Information Servers", também conhecido como "Wide Area Information Service") foi desenvolvido pela Thinking Machines Corporation com o patrocínio corporativo da Apple Computer, KPMG Peat Marwick e Dow Jones (GILSTER, 1995). Ele é um sistema que realiza procura automática de informações contidas em bancos de dados espalhados pela Internet. Assim, o usuário envia uma palavra-chave a um servidor WAIS que, por sua vez, devolve uma lista (que é ordenada pelo grau de sucesso da busca) dos documentos que contêm a palavra especificada (RANGEL, 1996b).

\section{Chat}

O chat é uma conversa "via teclado" entre usuários da Internet, realizada em tempo real. Esse serviço permite que centenas de pessoas de diferentes partes do mundo conversem simultaneamente pela rede, desde que possuam o mesmo software.

Os assuntos das conversas podem ser os mais variados possíveis, existindo, no entanto, "salas" de chat reservadas a conversas sobre assuntos específicos. Segundo GARCIA (1997), no campo educacional o chat pode ser utilizado pelos professores para promover encontros virtuais com seus alunos ou outros especialistas da sua área.

Alguns softwares de chat permitem uma conversa sonorizada, criando uma espécie de telefone via computador. Nesse caso, são necessários uma placa de som e um microfone acoplados ao computador.

\section{Videoconferência}

A videoconferência consiste em uma discussão em grupo ou pessoa a pessoa na qual os participantes estão em locais diferentes, mas podem ver e ouvir uns aos outros como se estivessem reunidos no mesmo local (CARNEIRO \& SCHNACK, 1999). Ela pode ser implementada na Internet ou em outras redes de computadores, em redes de comunicação e através de satélites.

Essa forma de comunicação pode ser utilizada em diferentes ambientes, como escolas, universidades, bancos, indústrias, entre outros, com o objetivo de garantir uma melhor compreensão da mensagem e uma economia de tempo e dinheiro (SISCOUTTO, 1997). 
Para CARNEIRO \& SCHNACK (1999), a videoconferência é atualmente o meio que mais fielmente reproduz os elementos de uma aula presencial, propiciando a interação do aluno com o professor e com os demais alunos, além de permitir o compartilhamento de aplicativos e a transferência de arquivos, dependendo do tipo de software utilizado.

Para a implementação da videoconferência via Internet são necessários uma câmera e um microfone acoplados ao computador. Atualmente existem vários fabricantes que produzem diversos modelos de câmeras para videoconferência. De modo geral, os equipamentos de hardware e software vêm sofrendo uma diminuição gradativa nos custos, graças à concorrência entre os fabricantes e à crescente popularização dessa forma de comunicação.

\section{World Wide Web}

A World Wide Web (conhecida também como WWW, W3 ou Web) é um sistema hipermídia distribuído executado na Internet e baseado no modelo cliente-servidor. Ela foi desenvolvida em 1992 por Tim Berners-Lee, do European Particle Physics Laboratory (CERN) de Genebra, na Suíça (LEE et al., 1994).

De acordo com LEMAY (1998), a Web é um sistema de informação em hipertexto, gráfico, distribuído, independente de plataforma, dinâmico, interativo e global. Para CASTRO et al. (1997), a interface gráfica amigável, surgida com a Web, aproxima da Internet pessoas que antes não se sentiam confortáveis com outros protocolos de acesso.

Segundo LEMAY (1998), não existe uma entidade que é dona ou que controla a Web. Mas existem dois grupos de empresas que possuem grande influência sobre sua aparência, seu comportamento e seus rumos. O primeiro é o World Wide Web (W3) Consortium, sediado no Massachusetts Institute of Technology (MIT) e no Institut National pour la Recherche en Informatique et Automatique (INRIA), da França. O W3 Consortium é formado por pessoas e empresas interessadas em definir as linguagens e protocolos da Web. $O$ segundo grupo é formado pelos fabricantes de navegadores que, embora apóiem e sigam as diretrizes do W3 Consortium, incluem novos recursos nas novas versões de seus softwares.

A Web é formada por documentos hipermídia concentrados em computadores-servidores espalhados por todo o mundo. Os usuários acessam 
esses documentos através de um programa navegador concentrado em seu computador. Como os documentos da Web são hipermídia, os usuários podem receber a informação em diferentes formatos: texto, figuras, áudio, vídeo, etc. Os links dos documentos permitem que o usuário navegue de um documento a outro (ou seja, de um servidor a outro) com total transparência no que diz respeito à localização do documento. Os documentos podem ainda ser interativos.

Os documentos são criados através da linguagem HTML ("HiperText Markup Language"), que utiliza tags (marcações) que informam ao navegador como exibir o documento. Na edição de um documento HTML, as tags ficam entre os sinais "<" e ">", aparecendo geralmente em pares (tag de abertura e tag de fechamento). Por exemplo, a tag $<A>$ mostrada a seguir informa ao navegador que ele deve exibir um link no documento atual que permitirá ao usuário navegar até outro documento (menu_princ.htmI). Já a tag 〈IMG> (que não possui um par) informa ao navegador que ele deve exibir no documento uma imagem chamada image.jpg.

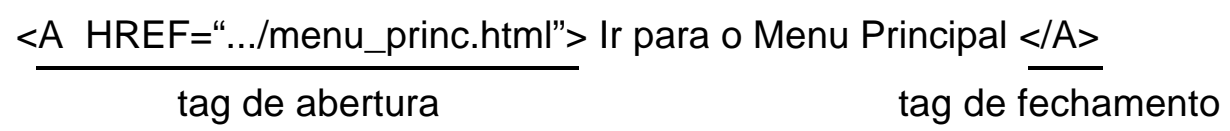

$<I M G$ SRC=“.../image.jpg”>

Além da multimídia, a linguagem HTML permite a inclusão de campos de formulário (forms) nos documentos, onde o usuário pode enviar informações ao servidor. Segundo LEMAY (1998), a criação de um formulário envolve duas etapas: a criação do lay-out do formulário (sua aparência), e a criação de um programa no computador-servidor para processar as informações enviadas pelo usuário. É muito comum as empresas solicitarem informações pessoais de seus clientes (ou potenciais clientes) pela Web, o que geralmente é feito através dos formulários.

$\mathrm{Na}$ Web, é dado o nome de site a um grupo de documentos HTML relacionados e que ficam concentrados em um servidor. A home-page é a página (documento) principal de um site (mas esse nome também é popularmente usado para referir-se a qualquer documento HTML da Web).

Os documentos são localizados na Web através do seu URL ("Uniform 
Resource Locator"), que é o padrão de endereçamento da Web. O URL permite que cada página da Web tenha um endereço único. Um exemplo de URL é: http://www.usp.br.

De acordo com MAGALHÃES (1997), o URL é composto de um protocolo (no caso do URL anterior o protocolo é o http - "HiperText Transfer Protocol", mas poderia ser outro, como o ftp ou o gopher), de um separador padrão (“://’) e do chamado domínio (www.usp.br). Alguns URL's podem ainda conter o nome do diretório onde está o arquivo a ser exibido pelo navegador, além do nome do arquivo. Como exemplo, no endereço a seguir o arquivo estima.htm (que está no servidor dentro de um diretório chamado estrutura) será exibido pelo navegador: http://www.eletropaulo.com.br/estrutura/estima.htm. Portanto, o URL apresenta o formato: protocolo://domínio/diretório/nome_do_arquivo. O URL pode também conter um elemento âncora (por exemplo, \#final), que é utilizado para acessar um trecho específico do documento. No caso de um documento longo, a âncora anterior poderia ser utilizada para acessar o final do documento, por exemplo.

Existem muitos editores HTML no mercado, variando entre eles os recursos oferecidos e a facilidade de uso. Alguns dos mais comuns são: o Composer (da Netscape), o FrontPage (Microsoft) e o Dreamweaver (Macromedia). Muitos locais da Web disponibilizam áreas para que os usuários armazenem suas páginas pessoais. São os chamados sites hospedeiros.

A inserção das empresas na Web é cada vez maior, já que seu potencial comercial é enorme. As empresas que atuam na área de vendas pela rede crescem a cada dia e têm a grande vantagem de permitir que seus clientes comprem seus produtos sem sair de casa (além de cômodo, não há a figura do intermediário). As pequenas e médias empresas também estão se convencendo que a Web é uma excelente plataforma local e mundial para seus negócios.

O próprio governo vem utilizando a Web de forma crescente como meio de divulgação de informações e leis. Serviços que antes eram realizados de outras formas, como as declarações de imposto de renda e cadastro de pessoas, já estão disponíveis via Internet.

A Web também apresenta um grande potencial educacional que precisa ser explorado. Seu ambiente multimídia aumenta o entusiasmo dos alunos e sua flexibilidade facilita a atualização da informação. Através dela, professores e alunos têm acesso a informações com diferentes formatos, não importa qual o 
assunto. Instituições de ensino podem divulgar experiências, disponibilizar artigos científicos, promover cursos. Professores podem criar suas páginas pessoais, expor o conteúdo de suas disciplinas, colocar resumos e referências de estudo.

Durante uma pesquisa na Web a quantidade de informação é tão grande que é necessário a utilização de serviços de busca, como o Altavista ou o Yahoo!. Esses serviços indexam milhões de documentos espalhados pela Web e, através de uma palavra-chave fornecida pelo usuário, apresentam uma lista dos documentos onde a palavra-chave foi encontrada. De acordo com CASTRO et al. (1997), o ambiente da Web é muito ágil em comparação com outros serviços de pesquisa bibliográfica, oferecendo muitas informações que não são encontradas em mídias convencionais. 


\section{Capítulo 4 - o Computador no Processo de Ensino- Aprendizagem: Algumas Exigências e Limitacõos}

De acordo com SANTOS (1993), nos idos de 70 o ensino apoiado por computadores prometia mudanças profundas nas formas de se conceber e administrar o processo de ensino-aprendizagem. Conforme afirma essa autora, "o advento de microcomputadores, no final da década de 70 , popularizou e disseminou a tecnologia da informática, permitindo sua entrada em muitos setores da sociedade, inclusive na escola. Quer fosse na linha de democratização da informação e da equalização das oportunidades educacionais, ou na direção da auto-instrução e do enriquecimento pessoal, ou ainda das possibilidades vislumbradas no desenvolvimento cognitivo, as promessas da informática mexeram com a cabeça dos educadores de diferentes matizes teóricos e ideológicos" (p.27).

Para a autora, essas promessas também chegaram ao Brasil. Enquanto que os anos 80 foram os anos da pesquisa universitária sobre a efetividade pedagógica da utilização dos computadores nas escolas públicas, os dias atuais estão assistindo, dentro das universidades, a instalação de centros de estudo e difusão das novas tecnologias da informação, evidentemente dentro das eternas limitações orçamentárias. Principalmente, verifica-se uma larga expansão dos computadores nas escolas particulares.

MEDEIROS $\mathrm{F}^{\circ}$ \& CINTRA (1999a) também chamam a atenção para essa expansão da utilização dos computadores no meio educacional, o que vem gerando investigações nas mais variadas esferas. Para os autores, as questões "quando", "como" e "onde" utilizar essa tecnologia direcionam as investigações. 
Os autores explicam que a questão do "quando" utilizar o computador está preocupada em "estabelecer critérios para subsidiar decisões a respeito do momento mais apropriado de utilizar esta tecnologia no processo instrucional. Hoje os computadores estão sendo utilizados nas escolas primárias, secundárias e nas universidades. Também faz parte da educação informal, onde os indivíduos trocam informações e experiências no cotidiano de suas vidas de forma muitas vezes inevitável, tais como: no trabalho, comércio, etc" (p.412).

Por poder ser utilizado nos mais diferentes ambientes, a questão do "onde" utilizar o computador torna-se apenas uma conseqüência de sua versatilidade. Os autores defendem que pelo fato do computador fazer parte, direta ou indiretamente, da vida da maioria das pessoas, é gerado um círculo onde sua influência gera uma maior demanda de seu uso, que por sua vez acaba por criar novas demandas.

Discutindo a questão do "como" utilizar o computador, MEDEIROS $\mathrm{F}^{\circ}$ \& CINTRA (1999a) admitem que hoje talvez seja essa a questão mais debatida e enfocada. Segundo os autores, existem várias maneiras de utilizá-lo na educação, cada uma tendo um enfoque. Para muitos, o modo como os computadores devem ser utilizados pode mudar os paradigmas atuais, pois suas características de flexibilidade e versatilidade fazem com que seja possível utilizá-lo como meio instrucional diferente dos tradicionais, abrindo perspectivas ilimitadas.

Este capítulo tentará mostrar algumas limitações e exigências relacionadas com a utilização do computador no processo de ensino-aprendizagem, através da indicação de caminhos que podem ser seguidos ou de caminhos que devem ser evitados, ambos baseados principalmente em experiências encontradas na literatura sobre o tema (ainda que relativamente escassa no que se refere a conclusões comprobatórias e irrefutáveis, ou livres de discussões ou críticas).

Essas duas dimensões, limitações e exigências, representam alguns dos obstáculos a serem conhecidos e superados em um processo de inserção de qualquer tecnologia em um ambiente social, seja ele a educação (foco deste trabalho), quer seja algum outro. Além disso, elas representam variáveis de contorno para as três questões discutidas nos parágrafos anteriores: "quando", "onde" e "como" utilizar o computador. Limitações e exigências, conforme tratadas neste trabalho, representam problemas, dificuldades, mentalidades, posturas ou outros fatores que podem limitar a possibilidade de aplicação e influenciar a 
qualidade da utilização do computador no processo de ensino-aprendizagem.

Este capítulo também discutirá, dentro do mesmo contexto, algumas das principais características e questões relacionadas com uma forma de educação que vem crescendo exponencialmente nos últimos anos (em número de adeptos e em importância), favorecida principalmente pela expansão das novas tecnologias, entre elas o próprio computador: a educação a distância.

\section{1 - O COMPUTADOR NA EDUCAÇÃO: DISCUTINDO ALGUNS PONTOS CRÍTICOS}

Segundo SANTOS (1995, p. 23), "o setor educacional é um dos setores mais conservadores entre os setores sociais, apresentando forte tendência a reagir às inovações tecnológicas. Quando tal reação torna-se impossível, a escola procura domesticar estas inovações, usando-as para reproduzir e reforçar práticas pedagógicas tradicionais, que passam a ser mascaradas em práticas mais modernas, porém inalteradas em sua essência". Assim, é muito comum o uso de computadores nas escolas apenas para "automatizar" práticas tradicionais de ensino, sem qualquer análise das conseqüências trazidas com essa utilização ou a consideração dos fatores pedagógicos envolvidos.

Para VALENTE \& ALMEIDA (1997), apesar dos apelos da mídia e das qualidades inerentes do computador, a sua disseminação nas escolas está hoje muito aquém do que se anunciava e desejava. Além disso, os autores comentam que "mesmo nos países como Estados Unidos e França, locais onde houve uma grande proliferação de computadores nas escolas e um grande avanço tecnológico, as mudanças são quase inexistentes do ponto de vista pedagógico. (...). Não se encontram práticas realmente transformadoras e suficientemente enraizadas para que se possa dizer que houve transformação efetiva do processo educacional, como por exemplo, uma transformação que enfatiza a criação de ambientes de aprendizagem, nos quais o aluno constrói o seu conhecimento, ao invés de o professor transmitir informação ao aluno" (p.46).

De acordo com esses autores, nos Estados Unidos o uso de computadores na educação é completamente descentralizado e independente das decisões governamentais. Essa utilização é resultado da pressão do desenvolvimento tecnológico e da competição estabelecida pelo livre mercado das empresas que 
produzem softwares, das universidades e das escolas. Apesar das mudanças de ordem tecnológica serem fantásticas e palpáveis, elas não têm correspondência com as mudanças pedagógicas. Nesse país, as escolas de primeiro e segundo graus empregam o computador amplamente para ensinar conceitos de informática ou para "automação da instrução". Nas universidades, o computador está sendo utilizado como recurso para o aluno realizar tarefas. Hoje o computador já passou a fazer parte da lista de material do aluno de graduação. O aluno sai da universidade com um bom conhecimento sobre o uso da informática, no entanto, o processo pedagógico envolvido no preparo do aluno de graduação ainda não sofreu mudanças profundas, sendo ainda enfatizado basicamente a transmissão de conhecimentos.

Segundo os autores, a França, por sua vez, avançou em muitos aspectos da informática aplicada à educação, embora em síntese pode-se afirmar que não houve maiores mudanças em termos pedagógicos e os resultados positivos que foram verificados freqüentemente não foram previstos. Nesse caso, uma ressalva é necessária, já que o programa de informática na educação da França não tinha o objetivo de mudança pedagógica, mas sim o de capacitar o aluno a utilizar a tecnologia da informática.

Ainda segundo VALENTE \& ALMEIDA (1997), aqui no Brasil, o programa de informática na educação tem o objetivo de provocar mudanças pedagógicas profundas, ao invés de "automatizar o ensino" ou capacitar o aluno para trabalhar com o computador. No entanto, os resultados já obtidos não foram suficientes para sensibilizar ou alterar o sistema educacional como um todo. Além disso, apesar da existência de diversas experiências que apresentam mudanças pedagógicas enraizadas e produzindo frutos, essas experiências não se alastraram. Segundo os autores, isso ocorreu principalmente "pelo fato de termos subestimado as implicações das mudanças pedagógicas propostas no sistema educacional como um todo: a mudança na organização da escola e da sala de aula, no papel do professor e dos alunos, e na relação aluno versus conhecimento" (p.53).

Esses autores defendem que a promoção de mudanças pedagógicas não depende simplesmente da instalação de computadores nas escolas: a sala de aula deve deixar de ser o lugar das carteiras enfileiradas para se tornar um local onde os alunos e professores possam realizar um trabalho diversificado em relação ao 
conhecimento e o interesse. O professor deve deixar o seu papel de "entregador" da informação para ser o facilitador da aprendizagem. Já o aluno, deve deixar de ser passivo para participar ativamente da construção do seu conhecimento.

Além disso, VALENTE \& ALMEIDA (1997) também afirmam que a utilização de computadores na educação envolve muito mais do que fornecer ao professor conhecimentos sobre computadores ou metodologias de como usá-lo em sua disciplina. Por exemplo, existem dificuldades envolvendo a escolha do assunto do currículo a ser desenvolvido com ou sem o auxílio do computador. Além disso, os assuntos desenvolvidos durante o curso devem ser escolhidos pelo professor de acordo com o currículo e a abordagem pedagógica adotada pela escola. Assim, é o contexto da escola, a prática dos professores e a presença dos alunos que são os fatores que determinarão o que vai ser trabalhado pelo professor. Com os novos recursos, como a multimídia, as redes eletrônicas e a grande quantidade de softwares disponíveis, é transferida ao professor a responsabilidade de discernir entre as inúmeras possibilidades que se apresentam.

Felizmente, já é possível notar na literatura uma mudança de mentalidade em relação aos verdadeiros objetivos da utilização do computador e outras tecnologias na educação. Muitas pesquisas que estão sendo geradas não visam mais propor simplesmente uma máquina digital no ambiente escolar, mas sim discutir a introdução de um recurso poderoso no processo de ensinoaprendizagem, buscando sua melhoria através da consideração dos fatores sociais, econômicos, políticos, culturais e pedagógicos envolvidos. As mudanças estão ocorrendo de forma lenta, é verdade, o que não deixa de ser perfeitamente natural.

Como exemplo dessa tendência de mudança de mentalidade, CARNEIRO (1997) comenta que se há alguns anos atrás a discussão sobre a informatização do ensino tratava sobre a falta de recursos computacionais nas escolas e a busca pelos softwares que poderiam ser utilizados, hoje a questão é outra: como os recursos disponíveis, em termos de equipamentos e aplicativos, podem ser usados de maneira a propiciar uma melhoria real na qualidade do ensino?

Para FREIRE (1998), o que baseava inicialmente as investigações sobre o uso da informática na educação é a visão de que o uso do computador nas escolas promovia o aumento da produtividade, ou seja, mais gente sendo ensinada em menos tempo. Atualmente, ao contrário, é enfatizado o provável 
potencial oferecido pelo computador no desenvolvimento de habilidades cognitivas que proporcionarão melhores meios de ensino-aprendizagem.

De acordo com PROENÇA \& MAIA (1996), para que as novas tecnologias tenham sucesso e alcancem seus objetivos, não é suficiente que elas tenham qualidade e que haja uma pressão da sociedade a favor da sua utilização, mas também é necessário a consideração de aspectos relacionados com o sistema educacional, o funcionamento das escolas, a formação dos professores e o apoio à inovação, entre outros.

O que garante o sucesso do computador no processo de ensinoaprendizagem não é sua presença na sala de aula, mas sim como ele será utilizado pelos alunos e professores (MARCHETI \& BELHOT, 1998). REINHARDT (1995) também afirma que a tecnologia sozinha não é solução. Conquistar os benefícios potenciais dos computadores requer extensivo treinamento dos professores, novos materiais curriculares e mudanças nos modelos educacionais. Também é preciso avaliar a influência do computador na formação do homem e verificar se as novas técnicas estão atendendo a um projeto pedagógico, conforme defende LONGO (1999).

De acordo com VALENTE (1993), para a implantação do computador na educação são necessários basicamente quatro ingredientes: o computador, o software educativo, o aluno e o professor capacitado para usar o computador no meio educacional. Dentro deste contexto, serão discutidas logo a seguir algumas limitações e exigências relacionadas a cada um desses quatro ingredientes, quando inseridos em um processo de ensino-aprendizagem via computador.

No caso do primeiro ingrediente, ao invés da discussão ficar restrita a um elemento apenas (o computador), ela será estendida, de forma generalizada, a outras tecnologias que são utilizadas para facilitar ou sustentar o processo de ensino-aprendizagem através do computador.

Com relação ao segundo ingrediente, conforme já explicitado anteriormente no item 3.1.1, os softwares educativos são entendidos neste texto como sendo sistemas computacionais de apoio ao ensino, englobando os tutoriais, os sistemas multimídia, os sistemas hipermídia, os sistemas tutores inteligentes, entre outros. Assim, a discussão estará relacionada a todos esses sistemas, também de forma generalizada. 


\subsection{1 - O COMPUTADOR (TECNOLOGIA)}

As barreiras para a expansão do ensino através de computadores vão desde as culturais, passando pelas de ordem técnica e indo até as de ordem econômica (SILVEIRA, 1998). Portanto, ainda são muitos os obstáculos a serem vencidos para que o computador cumpra todas as promessas e predições de seus maiores defensores.

Pode-se notar que em relação a outros tipos de recursos, os equipamentos eletrônicos costumam receber inovações e melhoramentos em curtos espaços de tempo. Esse fato é particularmente verdadeiro para os computadores e seus periféricos. Assim, computadores cada vez mais rápidos estão disponíveis ao consumidor a uma periodicidade cada vez mais curta, o que pode ser explicado em parte pela grande concorrência existente entre os fabricantes. Segundo LANGLOIS (1998), o lançamento cada vez mais freqüente de novos modelos também ocorre no caso dos softwares e outros equipamentos de hardware.

Uma conseqüência inevitável desse processo é que todos esses recursos acabam ficando obsoletos na mesma velocidade. Outro ponto importante a destacar é que, apesar da disseminação cada vez maior dos computadores, o custo para a aquisição dos equipamentos de informática ainda é um dos principais problemas enfrentados pelas escolas, principalmente as públicas.

Dessa forma, na escolha de um recurso tecnológico a ser aplicado na educação, o tipo de modelo escolhido e o custo embutido são fatores relevantes que geralmente impõem sérias restrições à compra. A escolha correta deve estar baseada no contexto da escola e nas atividades onde os recursos serão utilizados, necessitando, portanto, de uma análise de custo-benefício fundamentado nos objetivos desejados. SENA et al. (1999, p.324-325) afirmam que "escolher a melhor tecnologia, tornou-se um grande desafio, pois em muitos casos os custos são relativamente altos, não se conhece a sua eficácia quanto aos resultados da aprendizagem do aluno, e ainda são de difícil utilização“.

Quando o próprio aluno é dono do seu equipamento, a decisão da escolha ganha um contexto particular, o que pode gerar conseqüências a médio e longo prazo: de nada adianta um professor desenvolver um software em CD-ROM se o aluno não possui um drive para esse recurso em seu computador, assim como não adianta criar aplicações que exijam as últimas versões de hardware e software. 
Depois de escolhida a tecnologia a ser utilizada, é importante que ela não imponha exigências ou interfira nas decisões do professor ou da escola. Uma disciplina ou curso não deve ser moldado em função da tecnologia, mas é a tecnologia que deve ser moldada de acordo com o curso, trabalhando para auxiliar o professor. Como defende CARLSON (1999), a tecnologia não deve ditar ao professor como ministrar seu curso.

Também é necessário ter em mente que a tecnologia está impregnada em um equipamento, em uma máquina. Sendo assim, pode cometer erros e falhar de forma previsível ou não. Para CARLSON (1999), a tecnologia é um grande recurso, mas apenas quando funciona. Pois computadores quebram, softwares "travam", servidores são desconectados da rede, entre outros problemas. Uma equipe de apoio é importante para essas situações, quando o professor não for capaz de resolver sozinho. O maior problema, segundo LANGLOIS (1998), é que muitas universidades ainda têm carência de pessoal técnico e de rede.

O computador, com sua impressionante capacidade de processamento, também pode proporcionar uma falsa sensação de segurança que nem sempre garante resultados satisfatórios. Assim, o homem pode cometer erros que podem ser multiplicados pelo computador, como é o caso dos cálculos ou atividades similares. Portanto, o importante é nunca confiar cegamente na máquina (LONGO, 1997).

LANGLOIS (1998) e LONGO (1999) chamam a atenção para uma outra questão relevante: com o extensivo uso das novas tecnologias, as práticas de auto-aprendizagem vêm aumentando. Esse fato pode trazer conseqüências negativas para o relacionamento social entre os alunos e professores e entre os próprios alunos, já que o ensino coletivo está sendo substituído pelo individual. Segundo LONGO (1999), a máquina não é capaz de substituir o contato humano, fundamental na educação.

No caso específico da Internet, alguns outros problemas podem ser observados. Muitos países ainda possuem sistemas de comunicação com taxas lentas, prejudicando o potencial da rede. De acordo com PROENÇA \& MAIA (1996), a Internet ainda é um recurso pouco viável se a quantidade de dados a transferir for elevada - problema enfrentado por muitas escolas. Para LANGLOIS (1998), uma boa infra-estrutura é essencial e o governo precisa apoiar o avanço das tecnologias da informação. 
LANGLOIS (1998) ainda chama a atenção para o problema da língua, pois somente os idiomas mais conhecidos podem ser usados nas redes internacionais. Esse fato, além de fazer com que as línguas menos conhecidas sejam menos utilizadas, pode criar barreiras aos alunos que não dominam outro idioma.

Mas ainda existem aquelas classes de problemas menos técnicos e relacionados a questões mais pedagógicas. Infelizmente, muitos educadores ainda utilizam a Internet apenas para disseminar e recuperar informação, ao invés de aproveitar seu potencial para a comunicação, a cooperação e a colaboração. Suas grandes virtudes, assim, são desprezadas.

De acordo com MORAN (1997), apesar da utilização da Internet na educação proporcionar uma série de dimensões positivas, como o aumento da motivação e do interesse, o aumento das conexões lingüísticas, geográficas e interpessoais, o desenvolvimento de novas formas de comunicação, o interesse pelo estudo de novas línguas, a riqueza de interações, entre outras, alguns problemas podem ser encontrados:

- há muita informação e pouco conhecimento na utilização da Internet na educação;

- há informações que distraem e que pouco acrescentam, fazendo com que se perca muito tempo na rede;

- os alunos se perdem facilmente no emaranhado de possibilidades de navegação;

- existe uma impaciência por parte dos alunos em mudar de um endereço para outro;

- nem sempre é fácil conciliar os diferentes tempos dos alunos. Na pesquisa individual esses diferentes ritmos podem ser respeitados; já nos projetos em grupo, vai depender muito da forma de coordenação do trabalho e do respeito entre os membros;

- a participação dos professores é desigual: alguns acompanham e supervisionam os projetos, enquanto outros permanecem a distância, ficando para trás no domínio das ferramentas.

Para MORAN (1997), é possível atingir resultados significativos com a Internet se ela estiver integrada em um contexto estrutural de mudança do 
processo de ensino-aprendizagem, onde professores e alunos vivenciam novas formas de comunicação e participação. Caso contrário, a Internet será mais uma tecnologia que reforçará formas tradicionais de ensino. "Se uma escola mantém um projeto educacional autoritário, controlador, a Internet não irá modificar o processo já instalado. A Internet será uma ferramenta a mais que reforçará o autoritarismo existente" (p.152). Assim, o autor defende que integrar é a palavrachave: integrar a Internet com outras tecnologias, integrar o mais avançado com as técnicas convencionais e integrar o humano e o tecnológico, dentro de uma visão pedagógica nova, criativa e aberta.

Por fim, é importante destacar que as novas tecnologias podem e devem ser encaradas como importantes recursos para a área da educação, com um enorme potencial para modificar práticas e métodos tradicionais. No entanto, conforme afirmam SOARES \& MENDONÇA, ARAÚJO (1999), a tecnologia não é o aspecto mais importante no processo de aprendizagem.

Muitos recursos surgiram ao longo da história, declarando promessas de revolucionar a educação, mas que acabaram falhando no meio do caminho. Dessa forma, a utilização da tecnologia deve ser planejada dentro de um contexto que contemple a educação como um todo, considerando todas as suas fases e seus personagens, e sempre orientada pelos verdadeiros objetivos educacionais. Caso contrário, a tecnologia mostrar-se-á como mais um recurso que traduziu o formato de algumas práticas e métodos de ensino, sem no entanto modificar a substância, a essência. "Tecnologia educacional é, por exemplo, usar uma lata de água, um pedaço de madeira e uma pedra para explicar a flutuação dos corpos; apertar a tecla de um vídeo sobre o assunto e deixar os alunos o assistirem passivamente, em contrapartida, nada tem de tecnologia" (SEABRA, 1993, p.45).

Portanto, a questão não é modernizar, introduzindo uma nova ferramenta que corresponde às exigências do mercado de trabalho, mas sim revolucionar o processo de aprendizagem (BOARETTO Jr., 1996).

\subsection{2 - O SOFTWARE EDUCATIVO}

De acordo com BRANDÃO (1998), desde a construção das primeiras formas de representação e transmissão do conhecimento, como os enigmáticos hieróglifos egípcios, até as mais sofisticadas interfaces gráficas presentes nos 
softwares multimídia, o homem vem concentrando esforços no sentido de desenvolver meios capazes de transmitir de forma eficiente e eficaz os conteúdos gerados nos diversos setores da sociedade.

No contexto da educação, a fase de produção artesanal dos programas educativos - outrora desenvolvidos através de linguagens de programação como o Basic, Pascal ou o Fortran -, agora dá lugar à produção em série de programas de computadores que utilizam sofisticadas ferramentas multimídia, princípios de inteligência artificial, realidade virtual, etc, o que aumenta ainda mais a necessidade de se verificar o impacto dessas tecnologias, de se estabelecer critérios para sua escolha e de se definir características mais coerentes com sua especificidade.

Ainda segundo BRANDÃO (1998), com todos os recursos tecnológicos atualmente disponíveis para a produção de software, principalmente após a criação do hipertexto e da hipermídia, da proliferação das linguagens de programação orientadas a objeto e do lançamento de ferramentas que exploram a multimídia, foi possível observar nos últimos anos um boom dos softwares educativos, quer seja na modalidade comercial, shareware ou freeware - fato que favoreceu sua presença nas escolas.

Por causa da utilização de linguagens mais avançadas e recursos multimídia cada vez mais simples de serem absorvidos e administrados pelo usuário, a produção de software educativo não apenas se tornou uma atividade possível de ser realizada no âmbito das instituições de ensino, mas também ofereceu maior liberdade de criação, inclusive para o próprio professor.

BRANDÃO (1998) também comenta que, sob o ponto de vista da sua utilização e dos objetivos propostos, o software que o professor utiliza no processo de ensino-aprendizagem é, por definição, educativo (assim como qualquer outro material utilizado). No entanto, é preciso destacar a definição de software educativo como um produto orientado a diversas finalidades pedagógicas, concebido de modo a ser aplicado a diferentes estratégias e podendo ser construído com ferramentas mais ou menos complexas, como as da inteligência artificial.

Infelizmente, muitos softwares educativos encontrados na prática não foram desenvolvidos seguindo orientações pedagógicas e tampouco foi considerado o contexto educacional específico no qual foram (ou seriam) 
implantados. Para SOUZA, WAZLAWICK \& HOFFMANN (1997), muitos softwares colocam o aluno em uma posição passiva durante a recepção da informação, reproduzindo o que ocorre no processo de ensino tradicional.

Os softwares educativos imitam largamente o que ocorre na escola. Como a escola é altamente dependente dos livros, a maioria dos softwares possui uma "arquitetura de virar página", ou seja, telas com texto são apresentadas aos alunos, que têm como único trabalho "pressionar um botão para ir para a próxima página" (SCHANK, 1994). Portanto, uma experiência passiva como no ensino tradicional. Fazendo um comentário relacionado a esse fato, PANQUEVA (1997) lembra que o computador, ao mesmo tempo que permite um grau máximo de INTERatividade (onde há interação de diálogo entre o usuário e a máquina, e onde o primeiro está em controle do que acontece, dentro dos condicionamentos do micro-mundo em que a ação se desenvolve), também pode permitir uma grau zero de interação (a chamada ENTERatividade: o usuário limita-se a apertar ENTER para continuar).

Segundo BRANDÃO (1998), circulam atualmente pelas escolas milhares de softwares auto-intitulados "educativos", ou porque exploram imagens e conteúdo do universo das crianças, ou porque anunciam a participação de professores na sua elaboração, como se isso representasse um certificado de garantia de qualidade. Para esse autor, a ausência de filtros que possam assegurar um maior controle da qualidade do software educativo e, ao mesmo tempo, orientar professores e pais na melhor escolha, favorece a proliferação no mercado de produtos cujo potencial educativo levanta uma grande interrogação.

LONGO (1999) comenta que nos cursos multimídia empacotados o aluno acaba tendo um comportamento automatizado e vai perdendo sua capacidade crítica. SANTOS (1993), aliás, vê um culto e uma trivialização em torno das aplicações multimídia. "Se unirmos, em um só programa educacional, textos, gráficos, imagens, trechos de vídeo, seqüências animadas - uma verdadeira overdose de recursos - para apresentar informações segundo diferentes formatos, qual será o verdadeiro benefício educacional obtido? Será que precisamos de fato utilizar tantas mídias, tantos recursos tecnológicos de uma só vez? Educação é um quiosque de vendas onde o possível comprador precisa ver todas as "vantagens" da mercadoria eventualmente a ser adquirida?" (p.29).

SCHANK (1994) afirma que muitos programas multimídia falham porque 
simplesmente somam vídeo, gráficos e outras mídias em um ambiente onde não há participação do aluno. Como assistir à televisão, o usuário pode mudar de canal, mas não pode alterar a programação. Esse autor defende que os softwares educacionalmente efetivos são ativos - e não passivos - e permitem que o usuário "faça" - e não simplesmente "assista".

A conclusão é que embora nos programas hipertexto e/ou multimídia o aluno seja solicitado a apertar teclas e avançar pelas unidades de informação, ele pode cognitivamente permanecer bastante passivo.

Um grande equívoco nessa discussão, no entanto, é concentrar a culpa nos recursos em si. Como o próprio nome diz, recurso (como a multimídia, a hipermídia ou o hipertexto) é um elemento utilizado visando um fim: no caso, a criação do software educativo. Assim, não é a sua simples presença que provoca grandes decepções ou resultados educacionais nulos. Pelo menos sob a perspectiva do recurso, os insucessos podem estar muito mais próximos de uma escolha incorreta dos objetivos pedagógicos que são esperados com o seu emprego ou ao modo como ele é metodologicamente inserido no projeto do software.

Várias são as razões responsáveis pelo insucesso e baixa qualidade de muitos softwares educativos encontrados na prática, além daquelas relacionadas ao mal emprego dos recursos. Entre elas, estão: o pouco preparo dos professores para utilizá-los, a pressão mercadológica dos fabricantes de hardware e software, o custo para desenvolver ou adquirir software de qualidade e o tempo requerido para o desenvolvimento e implantação. Outras razões ainda existem, onde algumas das mais críticas referem-se ao processo de desenvolvimento do software e, portanto, estão mais diretamente relacionadas às estratégias, decisões, etapas e atividades escolhidas e executadas de modo a materializar a criação do produto-software.

Conforme defendem KOZAK et al. (1998), o sucesso de um aplicativo computacional é reflexo imediato do seu processo de desenvolvimento, que tanto pode ser uma tarefa construtiva e bem organizada, quanto um caos de papéis e pessoas - o que fatalmente levará a inúmeros problemas no produto final. Para os autores, "não só a existência de metodologias, mas a conscientização de sua necessidade junto aos envolvidos no processo de desenvolvimento e o comprometimento da equipe de trabalho são fundamentais na busca da qualidade 
do processo e, consequentemente, do produto. Sem esse envolvimento, qualquer metodologia, por melhor que seja, pode transformar-se num processo burocrático, cumprida pelo simples fato de ter de ser cumprida, perdendo seu objetivo" (p.1011).

As etapas do processo de desenvolvimento de um software educativo não podem estar fundamentadas em teorias de aprendizagem ultrapassadas ou que não foram corretamente traduzidas para o ambiente do software. Além disso, etapas importantes do desenvolvimento, como o teste, a verificação e a validação do sistema não devem ser ignoradas ou deixadas em segundo plano (essas três etapas podem ser entendidas, respectivamente, como a realização de testes de funcionamento, a aplicação de critérios de avaliação com o propósito de determinar a aceitação ou liberação do software, e a colocação do aluno em contato com o software com o propósito de verificar se os objetivos e metas são alcançados). A importância dessas etapas é capital, já que através delas é possível verificar se o software funciona, se realmente corresponde ao produto desejado e se atende aos objetivos, considerando-se os diferentes pontos de vista: de técnicos, educadores e alunos. SEABRA (1993), por exemplo, defende que o protótipo desenvolvido deve ter muitas horas de teste com os alunos, com o devido acompanhamento especializado, para possíveis modificações e a validação definitiva.

BRANDÃO (1998) levanta algumas questões que podem auxiliar a verificação e a validação de um software educativo:

- Qual o objetivo do software educativo?

- Quais as estratégias didáticas utilizadas?

- Qual o público-alvo?

- De que maneira o software explora os conteúdos?

- Quais os problemas apresentados?

- Quais os impactos provocados pelo software?

- Qual o grau de interatividade?

- Como é a interface utilizada?

- Qual a avaliação final por parte do usuário?

- Quais as contribuições do software à concessão dos objetivos didáticos propostos? 
A utilização de computadores na educação reclama a existência de softwares adequados e de qualidade. ROCHA \& CAMPOS (1993, p.32) definem qualidade de software como "um conjunto de propriedades a serem satisfeitas em determinado grau, de modo que o software satisfaça as necessidades de seus usuários". Como os usuários do software podem ser alunos, professores, desenvolvedores e mantenedores, o conceito de qualidade terá um significado diferente para cada uma dessas categorias, já que cada uma deverá refletir o seu ponto de vista particular. Essas autoras ainda comentam que a qualidade não surge espontaneamente, mas sim através de um conjunto de procedimentos cuidadosamente observados ao longo de todo o processo de desenvolvimento do software.

Por causa de sua característica multidisciplinar, SEABRA (1993), CAMPOS, CAMPOS \& ROCHA (1996), CELINSKI (1998) e MEDEIROS F \& CINTRA (1999b) defendem que o desenvolvimento de software educativo seja realizado por uma equipe também multidisciplinar. De acordo com HANNAFIN \& PECK (1988), as vantagens em se trabalhar com uma equipe de especialistas em áreas diferentes $\mathrm{e}$ complementares superam as desvantagens, como as relacionadas ao aumento dos custos de desenvolvimento. A equipe pode ser constituída de educadores, psicólogos, especialistas no conteúdo específico, ilustradores, redatores e por profissionais da área de informática.

Sobre características que o software deve possuir, é possível encontrar na literatura muitas sugestões ou recomendações, sendo a maioria baseada em experiências pessoais relacionadas ao desenvolvimento de softwares educativos. Dentre os pontos importantes a destacar, um refere-se à interface empregada, cuja importância ganha dimensões especiais no caso desse tipo de software, já que ela representa o meio que traduz a comunicação entre o usuário-aluno e o sistema-software. Se antigamente a interface significava entrada e saída, hoje, impulsionada pelos avanços da informática, ela vem sofrendo evoluções no sentido de facilitar o diálogo entre homens e máquinas.

Deve haver um cuidado todo especial na concepção da interface, pois sua qualidade será refletida na maior ou menor facilidade que terá o usuário na utilização do software educativo e, portanto, na maior ou menor eficácia do produto desenvolvido (PROENÇA \& MAIA, 1996). A interface deve procurar 
atender aos anseios e necessidades do usuário (SILVEIRA \& ARRUDA, 1998). Além disso, é essencial que a interface desencadeie a ação e a reflexão.

CHUA et al. (1997) defendem que um bom balanço visual entre os elementos estáticos e dinâmicos dispostos na tela é muito importante. Os responsáveis pelo desenvolvimento do software devem gerenciar o espaço na tela de modo a garantir a distribuição das informações de forma clara. As cores são elementos importantes para capturar a atenção e seu uso correto centrará o foco do usuário nas informações mais importantes. Seu uso indiscriminado poderá levar à desorientação e à confusão.

Apresentações gráficas devem ser embutidas de forma otimizada na informação textual, pois figuras e textos podem até dificultar a aprendizagem se eles são (ou estão) psicologicamente não coordenados.

Uma questão importante relacionada à interface e que representa um fator crítico no desenvolvimento de bons programas é a interatividade. Segundo SOUZA, WAZLAWICK \& HOFFMANN (1997), é importante que o usuário possa interagir com o software por diversos meios, como através da resolução de problemas, análise de representações gráficas, etc.

PANQUEVA (1997) defende que, contrariamente ao que pensam muitos educadores, o lúdico ou divertido não é infantil. Assim, é possível criar em um software educativo situações atrativas, simpáticas ou de humor, que quebram a monotonia, ajudam a descontrair e alegram o espírito, sem comprometer seus verdadeiros objetivos.

PROENÇA \& MAIA (1996) e AZEMI (1997) citam as características gerais que um software educativo deve possuir. Entre elas, estão:

- interface simples e intuitiva;

- figuras digitalizadas e diagramas relacionados ao tópico;

- vídeos curtos e animações relacionadas aos conceitos e exemplos;

- exemplos interativos onde os usuários possam realizar cálculos e simulações;

- sistemas de orientação básicos (como indicador de localização no documento);

- sistemas de navegação lineares (avanço ou recuo ao nível da página) e não lineares (possibilidade de voltar até a página principal, etc); 
- sistemas de ajuda on-line;

- local onde os usuários possam colocar suas anotações, questões, comentários ou críticas;

- sistemas de auto-avaliação, testes, etc;

- bibliografia adicional;

- interface para outros aplicativos.

Além dessas, o projeto de um software educativo ainda poderia contemplar:

- interface na língua nativa;

- possibilidade de armazenar o histórico da navegação;

- permitir a impressão do conteúdo;

- facilidade para a leitura do código do programa;

- independência de hardwares de última geração;

- suporte ao trabalho cooperativo entre os alunos;

- possibilidade de o aluno ser autor ou co-autor da base de dados, compondo os nós e definindo as ligações (SANTOS, 1995);

- previsão ou possibilidade de realização de atualizações e modificações no software;

- senha e identificação para os usuários, garantindo a segurança dos dados.

De acordo com FERREIRA (1999), a rápida evolução dos programas de computador (entre eles os editores de texto e as planilhas eletrônicas) faz com que as versões mais recentes não consigam entender as versões mais antigas, e viceversa. Esse fato pode dificultar a realização de atualizações ou modificações dos softwares ou aplicações criadas há algum tempo.

Outras questões importantes relacionadas ou inerentes aos softwares educativos merecem alguns comentários. Uma delas, por vezes discriminada, refere-se ao grau de controle que o usuário deve ter sobre o sistema. SOUZA, WAZLAWICK \& HOFFMANN (1997) defendem que o ambiente do software deve estimular o raciocínio do usuário, levando-o a pensar, e fornecer autonomia de exploração e percurso. No entanto, a principal questão é saber quanto de autonomia fornecer. Defender uma autonomia irrestrita ao usuário, permitindo que 
ele tenha controle total de navegação sobre o software, ainda é uma opinião muito controversa.

De acordo com SANTOS (1997), as idéias iniciais que surgiram junto com os sistemas hipertextos, produziram argumentações favoráveis a uma liberdade total de exploração dos documentos. Atualmente, porém, muitos pesquisadores têm criticado essas idéias, defendendo que existe pouca evidência empírica que mostre uma contribuição educacional relevante na utilização da liberdade total.

A liberdade total pode fazer com que o usuário se perca mais facilmente pela rede de documentos. Também há o risco que o usuário, durante a navegação, siga por documentos que talvez ainda não deveriam estar disponíveis para o seu nível de aprendizagem. Portanto, não há garantias que ele, sozinho, irá escolher o melhor caminho ou fazer as melhores escolhas. Além disso, como fica responsável pelo andamento da sua aprendizagem, o usuário deve, além de preocupar-se com o conteúdo a ser aprendido, tomar decisões sobre quais caminhos seguir. Assim, os dois principais problemas relacionados aos sistemas hipertexto/hipermídia, a desorientação e a sobrecarga cognitiva (ver item 3.2.2), apesar de serem crônicos em maior ou menor grau, podem ser amplificados quando uma liberdade total é conferida ao usuário.

Se a liberdade total pode apresentar uma série de problemas, um controle rígido do programa sobre as decisões do usuário também pode apresentar desvantagens, como a perda de motivação e ações mecanizadas e obrigatórias por parte do usuário, limitando sua reflexão e liberdade de escolha no processo de aprendizagem. "Se, por um lado, uma liberdade sem limites pode prejudicar o ambiente educacional (fazendo aumentar demasiadamente a responsabilidade do estudante), o controle em excesso pode representar um retrocesso tecnológico, limitando as ações do estudante" (SANTOS, 1997, p.41). Assim, a decisão de adotar uma ou outra abordagem, se controle realizado pelo usuário ou pelo próprio software, não é uma questão simples. Na prática, conforme opinião de LARGE (1996), SANTOS (1997) e FREIRE (1998), o grande desafio não é escolher entre um ou outro tipo de controle, mas sim como encontrar um equilíbrio entre os dois. $\mathrm{Na}$ busca desse equilíbrio, as próprias características do aluno podem influenciar, como experiência anterior e conhecimento sobre o assunto.

Uma das soluções para o problema pode estar no fornecimento de roteiros prontos ao usuário. Os roteiros são seqüências pré-definidas de nós que formam a 
rede de documentos, possuindo ligações next e previous que foram implicitamente inseridas durante a sua criação (SANTOS, 1997). Eles também são conhecidos como caminhos (paths), rotas orientadas (guided-tours) ou scripts.

Embora os roteiros possam criar uma imposição excessiva sobre a navegação do usuário, criando uma seqüência rígida dos nós a serem visitados, há situações onde o aluno pode "fugir" do roteiro, de acordo com sua conveniência (SANTOS, 1997). Além disso, apesar de alguns sistemas hipertexto ou hipermídia já virem com roteiros definidos, existem aqueles que permitem que sejam criados, pelo professor ou aluno, novos roteiros, de acordo com as necessidades de aprendizagem. Permitir que professores ou alunos definam seus roteiros, aliás, é uma característica desejável para os softwares educativos.

Além do controle do usuário, uma outra questão que merece destaque refere-se à escolha do assunto ou curso a ser beneficiado pelo desenvolvimento de um software educativo. Para SILVEIRA (1998), é inegável que retrabalhar um material didático já existente para tirar vantagens das novas tecnologias pode ser um grande desafio. No entanto, um curso já preparado e conduzido eficientemente de forma tradicional pode ser difícil de traduzir, por exemplo, para uma forma online. Assim, é preciso haver uma ponderação entre as vantagens e desvantagens que poderão aparecer, quando da escolha de um assunto, material ou curso a ser traduzido para algum formato computacional. Nem todo curso ou disciplina precisa de um software educativo para fazer o aluno aprender, e o fato de ser ministrado sob a forma tradicional não torna o curso mais desmotivante ou menos eficaz sob o ponto de vista dos objetivos educacionais.

Por fim, e paralelamente a tudo que foi discutido aqui, deve ser perpétua a preocupação em reconhecer que, mesmo existindo comprovada qualidade, mesmo que todos os problemas e limitações sejam contornados ou resolvidos, não é o software que faz a diferença em termos de resultados cognitivos, mas sim a forma como ele é utilizado no processo de ensino-aprendizagem pelo professor. Segundo SANTOS (1995), a definição dos objetivos de aprendizagem e das estratégias pedagógicas é fundamental e deve ser feito antes da escolha de uma ferramenta computacional ou da sua integração no ambiente de aprendizagem completo. 


\subsection{3 - O ALUNO}

Para SEABRA (1993), em um mundo onde a quantidade de informação cresce a taxas gigantescas, é preciso preparar a relação com o saber em bases completamente diferentes das que são praticadas atualmente na escola. Não basta que os alunos apenas se lembrem das informações: eles precisam ter a habilidade e o desejo de utilizá-las, precisam saber relacioná-las, sintetizá-las, analisá-las e avaliá-las. Esses elementos, quando juntos, constituem o que se pode chamar de pensamento crítico, que, segundo esse autor, aparece na sala de aula quando os alunos se esforçam para ir além de respostas simples, quando tentam unir eventos não relacionados dentro de um entendimento coerente do mundo e quando desafiam idéias e conclusões.

Em um ambiente assim, o computador pode ser tanto um aliado quanto um obstáculo. Se for utilizado respeitando-se suas exigências e limitações, dentro de um contexto pedagógico planejado, ele pode contribuir para colocar o aluno em uma posição de construtor do seu próprio conhecimento, além de poder contribuir para incitar no aluno o pensamento crítico. Por outro lado, se for utilizado como outros recursos atualmente em uso (como o giz ou o retro-projetor), por causa de sua presença marcante e maior sofisticação, há o risco dele amplificar problemas existentes e, o que é pior, criar novos.

A questão de utilizar o computador para permitir que o aluno participe da construção do conhecimento é muito defendida na literatura. Por exemplo, SOUZA, WAZLAWICK \& HOFFMANN (1997) argumentam que o uso da informática na educação deve estar fundamentado em teorias que enfatizem o processo de construção do conhecimento pelo aluno. SILVEIRA (1998) também defende que no ensino através de computadores o aluno deverá abandonar o comportamento passivo do ensino tradicional e passar a ter um comportamento ativo, onde sua principal função será a de explorar o material didático disponibilizado e interagir com o professor e com os outros alunos. Assim, o professor não será mais o centro das atenções e o aluno, por sua vez, deverá aprimorar sua aptidão para a auto-aprendizagem e adquirir o controle dessa aprendizagem em diferentes níveis.

No entanto, é comum encontrar na prática (principalmente dentro das universidades), laboratórios de computadores utilizados pelos alunos durante uma 
ou duas horas por semana e separados integralmente das outras disciplinas, já que são empregados apenas para o ensino da informática (o computador é o objeto de estudo, não o meio de acesso ao conhecimento). Utilizar a tecnologia como uma disciplina à parte tem resultados práticos nulos ou questionáveis sob o ponto de vista da melhoria do processo de ensino-aprendizagem; a menos, é claro, que o objetivo seja realmente aprender informática - o que não é o caso aqui discutido.

SEABRA (1993) comenta que nesses laboratórios - lugar onde ocorre o "corpo-a-corpo" do aluno com a máquina -, quase sempre o aluno é obrigado a trabalhar em duplas, ou mesmo em trios, devido ao reduzido número de equipamentos disponíveis. Segundo CARNEIRO (1997), em uma sala cheia de máquinas os problemas técnicos também são comuns: arquivos são perdidos, as impressoras não imprimem. O equipamento acaba exercendo um fascínio sobre os alunos, o que dificulta chamar-Ihes a atenção para outra coisa. Além disso, muitos alunos ainda resistem ao uso do computador e outros não sabem como utilizá-lo. Também deve ser considerada a existência de diferentes perfis de alunos em uma mesma sala de aula.

Sem a intenção específica de apresentar uma solução para todos esses problemas, SEABRA (1993, p.46) propõe: "por que não levar o micro para dentro da sala de aula? Usá-lo como um instrumento do dia-a-dia do ambiente de estudo, uma ferramenta cotidiana de aprendizagem, um gerenciador de simulações e jogos na sala de aula, cruzando dados para pesquisas e fornecendo material para discussões e levantamento de hipóteses".

Porém, mesmo se o computador for utilizado dentro da sala de aula, muitos dos problemas existentes nos atuais laboratórios de computadores, alguns citados anteriormente, continuarão existindo. Além do mais, colocar o computador na sala de aula não vai garantir que ele esteja integrado às disciplinas, contribuindo para o processo de ensino-aprendizagem, já que os professores poderão utilizá-lo como uma calculadora sofisticada ou apenas para automatizar etapas da aula. Assim, talvez a questão central esteja muito mais próxima de como preparar professores e alunos para utilizarem os computadores de uma forma que possa haver uma contribuição ao processo de ensino-aprendizagem, do que discutir qual o melhor local para utilizá-los. Sabendo como preparar esses dois elementos, professor e aluno, a questão de onde utilizar (se no próprio laboratório, na sala de aula, na 
casa do aluno ou em outro local qualquer) talvez se torne uma mera questão de opção.

Essas questões envolvendo o papel e a preparação do professor, bem como outras questões relacionadas, serão tratadas no próximo item do capítulo. Sob a perspectiva do aluno, elemento que tem o foco neste item, alguns pontos podem orientar sua preparação e garantir maior eficiência e eficácia no uso das novas tecnologias.

Por exemplo, é importante considerar que alguns alunos que iniciam um curso de engenharia nunca tiveram acesso a um computador. Isso significa que não têm qualquer domínio sobre a máquina. Por ser um equipamento não tão óbvio quanto a televisão ou um aparelho de som, o computador exerce nesses alunos um fascínio que está muito mais próximo do medo e da insegurança.

Discutindo essa questão, HORVATH \& TELES (1998, p.4) defendem que os professores sejam capazes de fornecer aos alunos inexperientes "uma ponte que Ihes permita transpor a lacuna tecnológica, se quisermos erigir uma universidade prática, aberta à mais ampla faixa de estudantes, e não uma que atenda apenas à elite tecnológica".

Trabalhando com alunos neófitos, esses autores puderam constatar alguns problemas relacionados ao uso do computador. Apesar de apresentarem apenas indicações (mais do que firmes conclusões), os autores perceberam, por exemplo, uma tendência dos alunos a imprimir o material do curso quando esse comportava mais de 350 palavras. Mesmo cuidando para desestimular essa prática, os autores não conseguiram alterar significativamente esse comportamento dos alunos.

Com os alunos alegando que gostariam de consultar o material mais tarde ou que não era agradável ler na tela do computador, os autores não foram capazes de descobrir se a preferência pelo material impresso decorria realmente de alguma dessas razões ou estava relacionada à falta de experiência dos alunos, à impossibilidade (no caso) de armazenar o material no disco rígido (o material estava disponível na Web e os computadores não eram de propriedade dos alunos), ao tipo de material apresentado ou a uma combinação desses fatores.

Os autores também observaram que os problemas com o computador tendem a gerar altos níveis de frustração e ansiedade nos alunos, bem como um comportamento inadequado e não-produtivo na tentativa de resolvê-los, caracterizado pela reincidência nos mesmos erros. "Tivemos a impressão de que 
as dificuldades dos estudantes não foram causadas somente pela falta das qualificações requeridas para diagnosticar o problema, nem pela falta de habilidades e conhecimento no uso do computador para resolvê-lo, mas principalmente pelo elevado grau de ansiedade, que bloqueou o racional, dando lugar a um comportamento de motivação predominantemente afetiva. Também notamos freqüentemente que os estudantes tendiam a sentir-se embaraçados ou envergonhados diante de tais problemas, e inclinavam-se a manifestar uma visão antropomórfica do computador, atribuindo-Ihe sentimentos negativos ("os computadores não gostam de mim", "ele não quer me ouvir") ou a recriminar-se pelo fracasso, formulando afirmações auto-depreciativas: "Eu sou estúpido com computadores", "Eu acho que quebrei esta droga", "Eu sempre estrago tudo", e assim por diante" (HORVATH \& TELES, 1998, p.9).

Comentando sua experiência sobre o uso da Internet, FERREIRA (1999) levantou alguns problemas decorrentes do que ela chama de "falta de uma cultura voltada para o uso da Internet". Trabalhando com alunos de graduação e pósgraduação, a autora observou que são muito variáveis a formação, os interesses e as habilidades dos alunos no uso da rede: enquanto uns utilizam-na normalmente, outros mostram indiferença. A autora sentiu certa dificuldade em fazer com que os alunos menos habituados à rede utilizassem seus serviços, como e-mail e a Web.

A autora também notou que, enquanto a utilização da rede como recurso adicional de ensino funcionou razoavelmente bem com os alunos de graduação, para os alunos de pós-graduação essa utilização deixou a desejar. "Como os alunos de graduação passam grande parte de seu tempo na universidade, os terminais utilizados por eles estão ligados à rede local ou em posições geográficas próximas e operam, em geral, com equipamentos e software similares, o que elimina grande parte dos problemas. Seus locais de armazenamento são os próprios servidores de rede da universidade, o que confere características comuns a todos, como a área de armazenamento destinada a cada usuário, e o acesso é praticamente instantâneo" (FERREIRA, 1999, p.2705).

Com relação aos alunos de pós-graduação, a autora comenta que eles constituem uma população heterogênea, operando equipamentos e softwares dos mais variados tipos e que, às vezes, não se comunicam entre si. "Alguns servidores, pertencentes ao serviço terceirizado, funcionavam muito mal, permanecendo fora do ar ou congestionados. $\mathrm{O}$ acesso às residências deixa muito 
a desejar, sendo feito através de linhas discadas, o que torna o tempo de acesso significativo. Aqueles alunos que não dispõem de equipamentos ligados à rede em suas mesas de trabalho e que necessitam acessá-las a partir de suas casas no final do dia, muitas vezes acabam por não fazê-lo por estarem fatigados, terem de competir pelo equipamento com o restante da família ou, simplesmente, por não terem o hábito de se ligarem constantemente aos serviços da rede. Desta forma consultam-na uma ou duas vezes por semana, quando estão mais tranqüilos e com menos compromissos. Nestes casos, a distribuição de papéis funciona de forma mais adequada, preferindo tais alunos recorrerem às máquinas de xerox, aos disquetes e às bibliotecas tradicionais" (FERREIRA, 1999, p.2705-2706).

A autora defende que antes da implementação de projetos educacionais mais complexos, é importante estabelecer uma cultura adequada de uso da infraestrutura visada. Também é necessário seguir uma metodologia para utilizar a Internet, com o intuito de atingir os resultados esperados e contornar os problemas, onde, para a autora, o mais sério é a inércia que os alunos apresentam para iniciarem espontaneamente a utilização da rede. Ela propõe alguns passos que o professor pode seguir para induzir os alunos a empregarem a Internet e realizarem pesquisas através dela:

- traçar o perfil dos alunos do seu curso;

- explicar detalhadamente aos alunos o processo que será utilizado no curso;

- tentar padronizar o software de rede ou de preparação das aulas (editores de texto, planilhas, editores de transparência, etc), facilitando o acesso dos alunos ao material distribuído;

- manter áreas na Web para armazenamento de materiais a serem distribuídos eletronicamente;

- utilizar informação a ser distribuída na forma compactada, diminuindo a quantidade de informação que trafega pela rede;

- fornecer o material com antecedência aos alunos, evitando problemas com aqueles que não acessam a rede freqüentemente;

- reservar um tempo para atender as solicitações dos alunos, tirando dúvidas e dando orientações caso a caso, já que se os alunos perceberem que não estão sendo atendidos, podem perder o interesse. 
Segundo MORAN (1997), ensinar utilizando a Internet exige uma boa dose de atenção do professor, já que diante de tantas possibilidades de busca, a navegação acaba se tornando mais sedutora que o trabalho de interpretação. Os alunos possuem a tendência de dispersar-se diante de tantas conexões possíveis e de acumular muitos textos, lugares e idéias. Além disso, colocam os dados mais em seqüência do que em confronto. As imagens animadas exercem um grande fascínio sobre eles, e os lugares visualmente menos atraentes são deixados para segundo plano, o que pode acarretar perda de informação. Assim, "é importante que o professor fique atento ao ritmo de cada aluno, às suas formas pessoais de navegação. O professor não impõe; acompanha, sugere, incentiva, questiona, aprende junto com o aluno" (p.149).

Um efeito negativo que o computador pode provocar no aluno é o sentimento de solidão e isolamento que a máquina incita. CARLSON (1999) defende que, para esses casos, atividades de aprendizagem ativa e em grupo podem ser especialmente efetivas. Assim, e-mail, discussões em classe e outras atividades podem contribuir para evitar o sentimento de isolamento do aluno diante do computador.

Uma outra forma de aprendizagem que também pode ser utilizada para contornar esse tipo de problema é a aprendizagem cooperativa. De acordo com SMYSER (1995), a aprendizagem cooperativa é uma técnica na qual os alunos ajudam uns aos outros durante o processo de aprendizagem, atuando como parceiros do professor e deles próprios. Segundo JOHNSON et al. (1998), na aprendizagem cooperativa os alunos trabalham em grupo para cumprirem uma determinada tarefa e produzirem um resultado final (a solução de um problema, uma análise crítica, um relatório de laboratório ou o projeto de um produto, por exemplo) sob condições que incluem os seguintes elementos:

- Interdependência positiva: para que o objetivo seja alcançado, cada membro do grupo é obrigado a contar com os outros. Se qualquer um dos membros falhar ao realizar a sua parte, todos os outros sofrerão as conseqüências;

- Responsabilidade individual: cada membro tem a responsabilidade de fazer sua parte do trabalho e repassar aquilo que aprendeu aos colegas; 
- Promoção da interação face-a-face: embora uma parte do trabalho seja feita individualmente, existem outras que são feitas interativamente, com os membros fornecendo orientações e estímulos uns aos outros, sempre objetivando o consenso;

- Uso apropriado das habilidades do grupo: os alunos são encorajados e auxiliados para desenvolver e exercitar a liderança, a comunicação, o gerenciamento de conflitos e a tomada de decisões;

- Auto-avaliação sobre o funcionamento do grupo: os membros do grupo estabelecem metas, periodicamente avaliam como estão trabalhando e identificam mudanças que poderão ser feitas.

A aprendizagem cooperativa é diferente da simples adoção de grupos de trabalho em sala de aula (FELDER \& BRENT, 1994; MARTINS, 1999). Uma atividade só pode ser qualificada como aprendizagem cooperativa quando os cinco elementos anteriores estiverem presentes.

As próprias empresas estão privilegiando cada vez mais a cooperação, que hoje já é um fator competitivo chave. Um currículo recheado já não é o bastante se o candidato não tiver facilidade para trabalhar em equipe ou para promover a integração social.

A aprendizagem cooperativa tem atualmente a tecnologia como grande aliada: apesar de poder isolar os alunos, a tecnologia também pode facilitar a implementação de um ambiente cooperativo entre eles, promovendo a troca de experiência e um sentimento de responsabilidade pelo êxito alheio, favorecendo e enriquecendo o relacionamento interpessoal. Redes de computadores, e-mail, chat, listas de discussão, ambientes próprios para aprendizagem cooperativa baseados em softwares, entre outros, podem ser transformados em grandes meios de acesso à aprendizagem cooperativa e ativa, quando bem utilizados pelo professor. Para SANTOS (1995), alguns produtos de software parecem propiciar o trabalho e a aprendizagem cooperativa, e os que suportam o desenvolvimento de um conjunto integrado de projetos comuns, visando atingir a melhor solução, são ideais para esse tipo de aprendizagem.

Como considerações finais deste item, mais do que vencer os problemas técnicos dos equipamentos, é preciso que o professor desenvolva nos alunos uma cultura favorável à utilização das novas tecnologias, de modo que eles possam 
aproveitar as vantagens do computador e da Internet em benefício próprio. Para isso é necessário que o professor ensine, oriente, apóie e monitore as atitudes e ações dos seus alunos, porém, funcionando como um parceiro e aliado e não simplesmente como um elemento hierarquicamente superior que determina suas atitudes e controla integralmente sua aprendizagem.

Mesmo que as novas gerações vindouras já entrarão na escola tendo um contato com a tecnologia muito mais prematuro que as atuais, é preciso ter consciência das diferenças de conteúdo e propósito existentes entre as tecnologias utilizadas para atividades lúdicas, de entretenimento ou atividades domésticas, e as tecnologias aplicáveis na educação (apesar da existência de certas similaridades). A Internet é um exemplo claro: ela tanto pode ser utilizada na educação, promovendo ótimas atividades que favorecem a aprendizagem, quanto utilizada para simples diversão ou passa-tempo. Assim, a questão da cultura ainda deverá ser um ponto crítico, mesmo no futuro.

Importante esclarecer que muitas questões relevantes, entre elas a de como integrar a tecnologia às várias disciplinas de modo a evitar que ela se torne uma disciplina à parte, estão sob a responsabilidades do professor, e não do aluno. Assim, o aluno acaba sofrendo as conseqüências, benéficas ou não, de muitas decisões originárias do professor, que é o verdadeiro elemento promotor das mudanças. No entanto, isso não diminui a importância da preparação do aluno para utilizar as novas tecnologias, cada vez mais disponíveis.

\subsection{4 - O PROFESSOR}

De acordo com SILVEIRA (1998), no ensino através de computadores o professor não deve ser mais o detentor do conhecimento e o doador das informações, mas sim o mediador, modelo e guia dos alunos, fornecendo-lhes estímulo e ajudando-os a aprender o que desejam. MARCHETI \& BELHOT (1998) defendem que o professor terá que desempenhar um papel de parceiro do aluno, funcionando como um mediador das novas tecnologias. Além disso, ele não poderá continuar utilizando palavras e práticas para audiências mais ou menos passivas, mas deverá utilizar metodologias que mobilizem integralmente o vigor e a criatividade dos alunos, visando a integração deles com o computador, ao mesmo tempo em que desenvolve habilidades profissionais e pessoais. 
Segundo MORAN (1997), mais do que a própria tecnologia, o que facilita o processo de ensino-aprendizagem é a capacidade de comunicação autêntica do professor, de estabelecer relações de confiança com os alunos, e pelo equilíbrio, competência e simpatia com que atua. CASAROTTO, KOPITTKE \& CASAROTTO $\mathrm{F}^{\circ}$ (1998) também afirmam que o agente promotor da nova escola que poderá ser criada com as novas tecnologias não é um equipamento computacional, mas o próprio educador, responsável pelo pensamento crítico dos alunos. SANTOS NETO \& SANTOS (1998) também concordam que as mudanças esperadas na educação não serão realizadas pelos computadores, mas pelos professores.

Portanto, a figura do professor representa o ponto central das mudanças que poderão ocorrer com a introdução do computador e outras tecnologias no processo de ensino-aprendizagem. Sua participação será fundamental em todas as etapas, já que será o principal responsável por garantir, promover e sustentar as mudanças. O papel que deverá desempenhar representa, assim, um ponto de equilíbrio, uma linha divisória que garantirá ou não o sucesso das novas tecnologias no ambiente educacional.

Não é possível promover as mudanças sem passar pelos professores. GARCIA (1997) afirma que é necessário prepará-los para esse novo mundo que está surgindo. Para SANTOS (1993, p.31), "sem o engajamento e a preparação dos professores, computadores na educação continuarão sendo mais uma das propostas potencialmente inovadoras não concretizadas". CORREIA \& VELASCO (1998) também defendem a preparação do professor como ponto primordial.

No entanto, conforme afirma CELINSKI (1998), os professores pouco ou nenhum treinamento têm recebido sobre informática durante sua formação. Esse treinamento, mais do que o mero conhecimento de softwares e comandos, referese a uma visão mais ampla que situe a tecnologia da informação no contexto educacional e que faça do professor um conhecedor da sua responsabilidade como agente transformador.

LANGLOIS (1998) também concorda que muito pouco treinamento tem sido fornecido aos professores, no que diz respeito às novas tecnologias. Como resultado, muitos ainda não estão preparados para utilizá-las em sala de aula, o que faz com que as mudanças não sejam realizadas e, portanto, métodos tradicionais continuem a ser predominantemente utilizados.

De acordo com SANTOS (1995, p. 35), "é necessário que o professor 
esteja mobilizado para transformar o cenário atual de nossas escolas, na direção de ajudar na construção de um cenário transformador. Além da natural resistência a inovações, os professores não estão sendo formados para saberem trabalhar de um modo novo e com um instrumento poderoso e versátil, porém ainda complexo para os não iniciados em informática. A formação de professores para o uso de inovações educacionais tem sido um ponto crítico para tal uso. Esta formação, via de regra, não tem sido privilegiada nas políticas governamentais e na prática das universidades, quer seja no âmbito de suas licenciaturas, quer seja em seus cursos de extensão".

Sendo o professor um epicentro das mudanças, é evidente que todo o sucesso decorrente da implantação das novas tecnologias na educação passa necessariamente pela sua formação, que deve ser construída via treinamentos e políticas que busquem capacitá-lo para o desenvolvimento de novas estratégias e atividades de ensino que integrem a tecnologia no ambiente educacional, de forma harmônica com os outros métodos e práticas de ensino utilizados (inclusive os mais tradicionais). Isso inclui preparar o professor para:

- dominar as tecnologias existentes ou disponíveis, tanto para utilizá-las de forma eficiente e eficaz, quanto para selecioná-las em função do contexto ou propósito;

- ter sensibilidade para escolher os conteúdos, atividades e disciplinas que poderão ser beneficiados com a utilização da tecnologia;

- saber adaptar a tecnologia ao curso ou disciplina, e não o contrário;

- saber como integrar a tecnologia apropriada nos conteúdos, atividades ou disciplinas escolhidas, dentro de um contexto pedagógico planejado que favoreça a construção do conhecimento pelo aluno;

- evitar tornar a tecnologia uma disciplina à parte, descontextualizada do objetivo principal que é melhorar o processo de ensino-aprendizagem;

- ter consciência das diferenças existentes entre os alunos, inclusive no que diz respeito ao conhecimento e manuseio dos computadores, Internet e outros recursos;

- preparar o aluno, tanto técnica quanto culturalmente, para dominar e tirar proveito das novas tecnologias, sob a perspectiva educacional;

- resolver pequenos problemas e percalços técnicos das máquinas; 
- não ter medo da máquina e das inovações, mas ao contrário, procurar conhecê-las e extrair delas qualidades aplicáveis;

- não ter medo em utilizar o equipamento por receio de danificá-lo;

- não "rotular" o computador e a Internet como recursos que só servem para atividades e interesses lúdicos;

- não ser embriagado pelo pensamento que exalta a tecnologia como a panacéia de todos os problemas da educação e que, portanto, deve ser utilizada a todo momento, em todo lugar.

SENA et al. (1999) chamam a atenção para a necessidade do professor dominar o uso do computador, bem como incorporá-lo em seu cotidiano. Para FARIAS (1997), o aumento da competência no uso das novas tecnologias é tarefa essencial daqueles envolvidos com educação.

Conforme afirmam VALENTE \& ALMEIDA (1997, p.59), "a formação de professores para implantar as transformações pedagógicas almejadas exige uma nova abordagem que supere as dificuldades em relação ao domínio do computador e ao conteúdo que o professor ministra. Os avanços tecnológicos têm desequilibrado e atropelado o processo de formação fazendo com que o professor sinta-se eternamente no estado de "principiante" em relação ao uso do computador na educação" .

CASTRO (1999) defende que a formação tecnológica do professor pode ser fomentada, entre outros fatores, a partir do desenvolvimento de habilidades cognitivas e operativas para o uso das mídias, e de atitudes favoráveis ao seu emprego e à inovação tecnológica em geral.

Para VALENTE \& ALMEIDA (1997), a formação do professor deve prover condições para que ele construa conhecimento sobre técnicas computacionais, entenda por que e como integrar o computador na sua prática pedagógica e seja capaz de vencer barreiras de ordem administrativa e pedagógica. Além disso, devem ser criadas condições para que ele possa recontextualizar a aprendizagem e a experiência vivida durante sua formação para a realidade da sala de aula, adequando as necessidades de seus alunos com os objetivos pedagógicos esperados.

Preparar o professor para utilizar as novas tecnologias também significa fornecer oportunidades para que ele, ao longo de sua carreira, atualize antigas 
habilidades e desenvolva novas. O problema é que conquistar novas habilidades não é tarefa fácil, além de exigir uma série de ações e medidas que envolvem aceitação, força de vontade, tempo e apoio. No caso do apoio, ele não deve vir apenas de outros professores, por meio de troca de experiências, por exemplo, mas também da direção da escola e do próprio governo. Aliás, o apoio também não deve ser um ato unilateral, mas sim uma ação recíproca, que sirva como combustível para um processo sinérgico que busque levar as potencialidades da tecnologia para dentro dos muros da escola.

A própria utilização da Internet no ambiente escolar cria exigências e requer novas habilidades do professor. De acordo com MORAN (1997), utilizar a Internet na educação pressupõe que o professor tenha uma atitude diferente da convencional. O professor não é mais quem centraliza a informação, já que agora ela encontra-se em bancos de dados, revistas, livros, textos ou em endereços espalhados por todo o mundo. Sua posição passa a ser, então, a de coordenador do processo. Embora a Internet seja uma tecnologia que por si só facilita a motivação dos alunos, pela novidade e pelas possibilidades inesgotáveis de pesquisa que oferece, o professor pode aumentar essa motivação ao criar um clima de confiança, abertura e cordialidade com os alunos.

A Internet será um ambiente ótimo para o professor que deseja atualizar-se ou comunicar-se mais. Por outro lado, será um problema para o professor que evita a tecnologia a todo custo ou que não está acostumado com a informação compartilhada e descentralizada. A Internet poderá tornar a defasagem entre essas duas classes de professores mais perceptível.

Pela necessidade da existência de uma interface entre os usuários (alunos) e o hardware em si, muitas vezes os professores terão, ou por escolha própria ou por necessidade, que desenvolver aplicações computacionais, como softwares educativos, páginas da Web, CD-ROM's ou pequenas aplicações. REINHARDT (1995) destaca um ponto importante envolvendo essa questão: só porque os professores das gerações anteriores eram capazes de escrever, não significava que eles pudessem criar seus próprios livros, assim, por que assumir que agora eles são capazes de criar seus próprios softwares hipermídia, mesmo considerando que a qualidade das ferramentas de autoria aumentou?

Segundo HINMAN (1999), a criação de páginas da Web e CD-ROM's com objetivos educacionais exige novas habilidades de quem os desenvolve, já que 
essas aplicações podem ser dinâmicas, interativas e ricas em multimídia. Assim, são necessárias as habilidades de artistas gráficos (para imagens), dos músicos (para sons), dos diretores (para vídeos), dos coreógrafos (para ambientes dinâmicos) e dos próprios professores (para a interatividade).

Dependendo do tipo de aplicação que o professor queira introduzir em seu curso ou disciplina, vai precisar de conhecimento nas áreas de programação (linguagens), redes, mídias, softwares de autoria, softwares aplicativos, etc, sobrecarregando o leque de habilidades exigidas.

Assim, integrar o computador e outras tecnologias dentro de práticas e métodos de ensino já utilizados, de forma que não haja choques metodológicos que coloquem em risco o processo de ensino-aprendizagem e que ao mesmo tempo represente uma nova concepção pedagógica, passa necessariamente pela formação do professor para o uso das novas possibilidades tecnológicas, e também na criação de condições e oportunidades para que o profissional adquira novas habilidades, o que, aliás, também deve ser encarado como uma parte importante da sua formação.

Além disso, conforme defendem VALENTE \& ALMEIDA (1997), a possibilidade de sucesso de projetos que buscam práticas pedagógicas inovadoras está em se considerar os professores não apenas como executores do projeto, responsáveis pelo uso dos computadores e consumidores dos materiais e programas escolhidos, mas principalmente como parceiros na concepção de todo o trabalho.

\section{2 - A EDUCAÇÃO A DISTÂNCIA}

A educação a distância está crescendo muito e se tornando uma das mais importantes tendências da educação (MAGALHÃES \& SCHIEL, 1997). Além de "educação a distância", também é possível encontrar na literatura os termos "ensino a distância" e "aprendizagem a distância", entre outros. É comum os vários termos serem utilizados indistintamente, já que muitos textos que tratam sobre o assunto não estão preocupados em considerar as diferenças existentes entre os termos "educação", "ensino" e "aprendizagem". Este texto utilizará "educação a distância" por estar mais próximo a seus objetivos e discussões.

Conhecer as principais características dessa forma de educação talvez seja 
tão eficaz quanto apresentar ou propor uma definição sobre o tema. Assim, podese observar que na educação a distância:

- o aluno e o professor podem estar separados no tempo e no espaço;

- a comunicação entre aluno e professor é realizada por alguma forma impressa ou tecnológica;

- o controle da aprendizagem é realizado mais pelo aluno do que pelo professor;

- por questões óbvias, a população estudantil é relativamente dispersa.

A abrangência de formas de educação sugeridas pelas características da educação a distância faz com que não haja um consenso sobre suas verdadeiras origens. Já longe das cartas de Platão, das epístolas de São Paulo ou da imprensa de Gutenberg, princípios comumente citados, sua origem recente está, segundo NUNES (1994), nas experiências de educação por correspondência iniciadas no final do século XVIII e com grande desenvolvimento a partir de meados do século XIX. Do início do século XX até a Segunda Guerra Mundial, várias experiências foram adotadas utilizando-se novas metodologias aplicadas ao ensino por correspondência que, depois, foram fortemente influenciadas pela introdução de novos meios de comunicação de massa, como o rádio.

NUNES (1994) cita que alguns dos métodos de educação a distância surgidos durante a Segunda Guerra foram utilizados, logo depois, em tempos de paz, tanto para a integração social dos atingidos pela guerra, quanto para o desenvolvimento de novas capacidades de trabalho nas populações que migravam em grande quantidade do campo para as cidades da Europa em reconstrução.

Segundo o mesmo autor, a partir de meados da década de 60 houve um grande crescimento da educação a distância, com a institucionalização de várias ações nos campos da educação secundária e superior, primeiramente na Europa e depois se expandindo aos demais continentes.

Além do rádio e dos meios impressos, ao longo das últimas décadas novos meios de comunicação (tecnologias) passaram a ser utilizados: televisão, telefone, audiocassete, videocassete, telex, computadores, softwares, entre outros. $\mathrm{Na}$ década de 90, a educação a distância passou a utilizar novas tecnologias: 
satélites, videoconferência, cursos multimídia, CD-ROM, redes de computadores e, mais recentemente, a Internet. Assim, nota-se que a educação a distância sempre foi beneficiada pelo desenvolvimento tecnológico. Como conseqüência, seu ambiente tem mudado rápida e radicalmente.

Apesar das diferentes tecnologias utilizadas, ainda hoje é possível observar a coexistência entre as várias formas de educação a distância que estão distribuídas pelo continuum que vai do ensino por correspondência, via material impresso, até os arranjos que utilizam satélite, redes de computadores ou a própria Web.

Dentre as várias tecnologias disponíveis, a Internet destaca-se por ser uma das principais responsáveis pelo crescimento que a educação a distância está tendo nos vários níveis de ensino, em um contexto mundial. Dentre os seus vários serviços utilizados para a educação a distância, destaca-se a Web. Esse ambiente tem ampla aceitação (crescente), é de fácil aprendizagem, permite a interface com vários recursos/serviços e independe da plataforma computacional usada. Quando utilizada em conjunto com outros serviços disponíveis na Internet, a educação a distância por meio da Web possui as seguintes vantagens:

- facilita a distribuição e o acesso ao material de ensino;

- facilita o suporte ao aluno;

- facilita a comunicação entre os próprios alunos;

- favorece a aprendizagem cooperativa;

- possibilita o atendimento individual;

- aumenta a motivação (DAUGHERTY \& FUNKE, 1998);

- permite a reprodução de aulas já ministradas;

- permite a aquisição de novas informações (externas);

- facilita atualizações ou modificações do material de ensino utilizado;

- utiliza diferentes tipos de mídias;

- facilita a autoria de materiais de ensino;

- reduz custos de distribuição.

Suas maiores desvantagens estão relacionadas ao seu caráter aberto. Assim, os testes, avaliações e as notas devem ser mantidos seguros, a fim de impedir cópias, proteger a privacidade dos alunos e evitar autorizações não 
permitidas (SCAPIN, 1997). Outros problemas referem-se a características próprias da Internet, como velocidade de acesso, etc.

\section{GERAÇÕES DA EDUCAÇÃO A DISTÂNCIA}

Alguns autores costumam dividir a educação a distância em diferentes gerações. As especificações que definem as diferentes gerações variam de acordo com o autor, mas são geralmente baseadas no tipo de tecnologia utilizada e o tipo ou grau de interação permitido entre os participantes.

De acordo com THORPE (1998), o ensino por correspondência que utiliza texto impresso e, ocasionalmente, comunicação escrita entre o aluno e o professor distante representa a primeira geração de educação a distância. A segunda geração utiliza formas de comunicação via correio e telefone, podendo também utilizar mídias visuais e áudio com texto, sendo o suporte ao aluno realizado via contato face-a-face, telefone e correspondência. A terceira geração utiliza mídias e tecnologias advindas da união das áreas de computação e telecomunicação.

KIRKWOOD (1998) também considera de primeira geração a utilização de texto impresso e comunicação postal. Para esse autor, a segunda geração utiliza, além do texto impresso, programas de rádio e televisão, audiocassetes e videocassetes, kits de experimento e até softwares de computadores. Já a terceira geração dá grande ênfase ao uso de tecnologias de comunicação para facilitar o diálogo entre os participantes do processo de educação.

Outros autores, SUN \& CHOU (1996), consideram quatro gerações em vez de três. Porém, independentemente da classificação utilizada pelos diferentes autores, nota-se que quanto mais crescente a geração da educação a distância, maior a facilidade de interação entre os participantes. Evidentemente, esse fato está ligado diretamente ao tipo de tecnologia utilizada.

Tecnologias mais antigas como correio, televisão e vídeo, além de outras típicas da primeira e segunda geração, permitem uma interação limitada. Por outro lado, tecnologias mais recentes, típicas da terceira geração, como a Web, o correio eletrônico e a videoconferência, criam potencial para novas interações entre alunos e professores. 


\section{TRANSMISSÃO SÍNCRONA E ASSÍNCRONA}

$\mathrm{Na}$ educação a distância a transmissão da informação pode ocorrer de duas formas: síncrona ou assíncrona. $\mathrm{Na}$ forma síncrona os participantes (professores, alunos, monitores, etc) podem estar em diferentes locais, mas devem utilizar a tecnologia ao mesmo tempo. Como exemplo, tem-se o caso da videoconferência e do telefone, que devem ser utilizados no mesmo instante pelos participantes. Na forma assíncrona, não é necessário que os participantes estejam no mesmo local e nem estejam utilizando a tecnologia ao mesmo tempo. Como exemplo, tem-se o caso do CD-ROM, do correio eletrônico e o acesso a uma página ou site da Web, que podem ser utilizados em qualquer instante desejado.

Assim, na forma síncrona há uma quebra da barreira do espaço: os interessados podem acessar a informação em um local diferente daquele que está sendo utilizado para gerá-la. Na assíncrona, além do espaço, há também a quebra da barreira do tempo: os interessados podem acessar a informação em um local e em um instante diferentes daqueles que foram utilizados para gerá-la (COSTA NETO, 1999).

O fato da transmissão ser síncrona ou assíncrona depende meramente do tipo de tecnologia utilizada. Assim, também é comum referir-se a uma ou outra tecnologia como síncrona ou assíncrona. Muitas formas de educação a distância trabalham com os dois tipos de transmissão (ou tecnologias).

\subsection{1 - QUESTÕES IMPORTANTES RELACIONADAS COM A EDUCACÃO A DISTÂNCIA}

A educação a distância representa uma mudança de paradigma em relação à educação tradicional presencial. Diferenças existem em todas as etapas que constituem essas duas modalidades de educação, tanto em forma, quanto em conteúdo e exigências. Aluno e professor também mudam seus papéis. Enquanto o primeiro vê aumentada sua responsabilidade sobre a aprendizagem, sendo exigida uma postura mais ativa, o segundo passa a ser um facilitador, devendo garantir condições para que o primeiro alcance seus objetivos.

GONÇALVES (1996) destaca alguns pontos que são críticos em um projeto de educação a distância: 
- a identificação das necessidades;

- a definição dos objetivos a alcançar;

- a seleção e organização do conteúdo;

- a elaboração dos materiais de ensino;

- a definição do esquema operacional;

- a organização das condições de aprendizagem;

- o esquema da avaliação.

Para CHIGANER \& BIONDI NETO (1999), é fundamental a definição das responsabilidades e atribuições de todos os envolvidos, de modo a garantir: o desenvolvimento e a produção dos cursos, a distribuição dos materiais de ensino, o suporte ao aluno, o apoio aos momentos presenciais (quando for o caso) e o apoio à realização de testes e provas.

Um programa de educação a distância deve estar sustentado por recursos humanos capacitados. O envolvimento de conhecimentos e especialidades de diferentes áreas exige a participação de uma equipe multidisciplinar, formada por professores, artistas, técnicos em informática, educadores, pessoal administrativo, psicólogos, etc.

De acordo com GONÇALVES (1996), na educação a distância a presença é revista, bem como a frequência, os objetivos e a forma das situações presenciais de contato dos alunos entre si e dos alunos com aqueles que os apóiam ao longo do processo de aprendizagem. Podem existir situações onde o único momento presencial é a avaliação final, também podem existir aquelas onde o momento presencial nunca acontece. Assim, haver ou não momentos presenciais é uma questão de estratégia, de plano de ação, de tomada de decisão. O fato de haver momentos presenciais depende das condições dadas para a concretização da educação a distância.

Na educação a distância é necessária toda uma preparação específica a fim de substituir o contato presencial. Como pode não haver a presença física do aluno, o professor deve cercar-se de meios para assegurar que a aprendizagem ocorra satisfatoriamente (COSTA NETO, 1999). Assim, ele precisa adotar uma nova postura no processo de ensino-aprendizagem. São obrigações suas: 
- entender a natureza e a filosofia da educação a distância;

- compreender seu novo papel, passando de transmissor da informação (educação tradicional presencial) para orientador e estimulador da aprendizagem;

- utilizar estratégias de ensino para garantir a instrução a distância;

- identificar as características e necessidades dos alunos;

- implementar e organizar atividades educacionais (discussões em grupo, aulas, etc);

- participar da elaboração do material de ensino utilizado;

- fornecer suporte ao aluno;

- dominar as tecnologias utilizadas no desenvolvimento do material de ensino, nas atividades educacionais e no suporte ao aluno;

- desenvolver formas de avaliação;

- no caso de um curso novo, participar do seu projeto e das etapas necessárias à sua implantação.

De acordo com TODOROV (1994), a educação a distância abre novas perspectivas ao professor, além de valorizar suas capacidades e ampliar seu magistério. Portanto, ela não irá substituí-lo.

Com relação aos alunos, na educação a distância eles geralmente fazem parte de um grupo heterogêneo. Segundo SCAPIN (1997), como estão dispersos geograficamente e temporalmente, os alunos podem viver em diferentes situações econômicas, sociais e até culturais. O conhecimento que cada aluno tem também diverge, assim como a velocidade da aprendizagem. Por causa disso, a duração de um curso pode não ser fixa. Conhecer as diferenças existentes entre os alunos, bem como respeitá-las, é função do professor.

Outro problema envolvendo os alunos refere-se ao fato deles ainda terem uma forte influência dos métodos presenciais, podendo sentir grande dificuldade em estudar a partir do seu próprio esforço individual. Aí que entra o papel do professor, promovendo a motivação e ajudando-os a desenvolver habilidades que envolvem independência e iniciativa.

Alguns fatores que podem melhorar o desempenho dos alunos na educação a distância, são: 
- experiência anterior em educação a distância;

- importância do conteúdo do curso para seus interesses pessoais ou profissionais;

- domínio das tecnologias utilizadas;

- suporte que recebe dos professores;

- contato com outros alunos.

Em um curso a distância é imprescindível o desenvolvimento de formas eficientes de comunicação entre o professor distante e o aluno. O chamado suporte ao aluno visa diminuir as dificuldades e problemas decorrentes das dimensões geográficas e temporais envolvidas.

No suporte ao aluno, o professor pode desempenhar diversas atividades: tirar dúvidas, indicar caminhos de pesquisa, fornecer materiais de estudo, indicar outras fontes de informação, sugerir formas que o aluno deve estudar, orientar o aluno sobre o material de ensino, servir como motivador, etc.

O nível de suporte ao aluno depende da tecnologia utilizada e da necessidade de interação entre aluno e professor. As novas tecnologias, como os serviços disponíveis na Internet, possibilitam o fornecimento de um bom suporte ao aluno, com uma comunicação de dupla via: o professor envia informações ao aluno, o aluno envia informações ao professor, de forma síncrona ou assíncrona. Nas tecnologias mais antigas, como a televisão, o rádio e o videocassete, o suporte ao aluno é mais precário, consequentemente a comunicação é limitada e ocorre com menos frequência.

Além da interação entre professor e aluno, em muitos casos é interessante ou necessário que ocorra também uma interação entre os próprios alunos, permitindo a troca de experiências, dúvidas, o trabalho cooperativo, o trabalho em grupo, etc, o que pode resultar em menor sensação de isolamento ou abandono e maior motivação. SHERRY (1995) defende que um sistema de educação a distância de sucesso envolve a interação entre professores e alunos, entre os alunos e o ambiente de aprendizagem e entre os próprios alunos.

Serviços da Internet como videoconferência, correio eletrônico e chat permitem colocar vários alunos interagindo ao mesmo tempo, criando literalmente uma sala de aula virtual. Portanto, as novas tecnologias possibilitam que os alunos trabalhem individualmente, mas não necessariamente sozinhos. 
O suporte ao aluno também costuma ser chamado por alguns autores de tutoria (ver por exemplo, MORAES, ROGRIGUES \& BARCIA, 1999). Assim, o professor distante é o tutor (protetor ou defensor, em latim), responsável por orientar e facilitar a aprendizagem dos alunos. Segundo GONÇALVES (1996), quando o professor assume o papel de tutor na educação a distância, ele não dá mais aulas, mas orienta e reorienta a aprendizagem dos alunos, ajuda no esclarecimento de suas dúvidas, identifica dificuldades, sugere novas leituras, organiza atividades de estudo em grupo, supervisiona a prática de oficina ou de laboratório, entre outras coisas.

Já o monitor, que ocupa uma posição subalterna ao tutor, é geralmente responsável por questões operacionais e de acesso tecnológico dos alunos, também contribuindo para a motivação e entusiasmo dos mesmos. Essa função geralmente é desempenhada por alunos.

Existem muitos autores que utilizam outros termos (também são comuns mentor e instrutor, ao invés de tutor e monitor, respectivamente) e vários usam mais que dois termos para designar as diferentes funções desempenhadas por professores e alunos (algumas classificações podem ser encontradas em: SHERRY, 1995; MAGALHÃES, 1997; MORAES, ROGRIGUES \& BARCIA, 1999; FREITAS et al., 1999).

Além do suporte ao aluno, a qualidade do material de ensino utilizado é outro fator crítico do qual depende o sucesso de qualquer programa de educação a distância. Se na educação presencial o professor é o principal responsável por levar o conteúdo do curso aos alunos, na educação a distância essa tarefa é assumida pelo material de ensino.

Uma definição mais ampla poderia incluir produtos tangíveis e intangíveis como sendo materiais de ensino para educação a distância. Assim, tem-se texto impresso, CD-ROM, softwares educativos, programas de rádio ou televisão, aulas via videoconferência, entre outros.

Os materiais de ensino devem ser preparados por profissionais de diferentes áreas, visando preencher as necessidades multidisciplinares dos alunos. O desenvolvimento de um bom material de ensino requer o conhecimento do tipo de público a ser atingido, já que ensinar crianças ou leigos é diferente de ensinar adultos ou profissionais experientes, bem como depende da escolha do tipo de meio de comunicação (tecnologia) a ser utilizado para distribuir o material. 
Com relação à tecnologia, a sua escolha deve estar baseada no escopo do projeto de educação a distância, na própria natureza do público-alvo, no grau de interatividade desejado, nos recursos financeiros disponíveis para investimento, entre outros fatores (COSTA NETO, 1999).

As tecnologias mais recentes utilizadas para educação a distância exigem grandes investimentos, tanto em equipamentos modernos e caros, quanto em infra-estrutura e mão-de-obra para suporte e manutenção. Algumas delas, como é o caso da Internet, exigem que o aluno tenha seu próprio equipamento, o que pode limitar o público potencial.

Apesar da importância da tecnologia, qualquer curso ministrado a distância deve estar orientado mais nas necessidades instrucionais de seus alunos do que na própria tecnologia. Segundo KIRKWOOD (1998), as novas tecnologias da informação e comunicação utilizadas na educação a distância são somente meios para se atingir um fim, e esse fim deve ser educacional, não tecnológico. As tecnologias em si não melhoram a qualidade de um sistema educacional, mas a forma como elas são utilizadas pode melhorar.

Um outro fator crítico na educação a distância é a avaliação. Para verificar se os objetivos de aprendizagem dos alunos foram atingidos, é preciso realizar avaliações, assim como ocorre na educação presencial. A avaliação na educação a distância envolve as seguintes decisões: escolha do tipo de avaliação (testes, trabalhos, provas, etc), o momento da avaliação (se durante o curso ou só no final) e o local da avaliação (na instituição responsável pelo curso, a distância ou adotando essas duas formas).

GONÇALVES (1996) defende que a exigência de avaliação presencial não pode ser tratada de forma dogmática. Existem situações onde a presença do aluno na avaliação é condição de aperfeiçoamento da aprendizagem: é o caso das avaliações que visam verificar habilidades motoras complexas. Em situações como essa, a não realização de uma avaliação presencial pode ser uma decisão irresponsável, já que, sendo imprescindível para a aprendizagem, torna-se um direito do aluno a ser respeitado.

Segundo a mesma autora, "na maioria das vezes em que, para fins de avaliação da aprendizagem, a presencialidade é exigida, isto acontece, menos por ser necessário e mais porque não se conseguiu desenvolver formas de avaliar que prescindam da presencialidade" (p.7). Uma situação de avaliação onde é legal a 
consulta a documentos de qualquer natureza, não tem porque ser presencial.

$\mathrm{Na}$ discussão envolvendo a avaliação do aluno, um fator importante merece comentários: a questão da segurança, que é responsável pela credibilidade de qualquer programa de educação a distância. Assim, devem ser desenvolvidos meios que garantam a originalidade e a autenticidade das provas ou trabalhos realizados, bem como de outras atividades educacionais. Também deve ser garantido ao aluno a entrega dos materiais de ensino e outros recursos utilizados, além da integridade de notas, freqüências e outras informações pessoais. Felizmente, a segurança é um fator cuja importância é crescente nas novas tecnologias, devido principalmente ao crescimento do comércio eletrônico (ecommerce) na Internet.

Mas não é apenas o aluno que deve ser avaliado, mas o próprio programa de educação a distância. Segundo MAGALHÃES (1997), é de suma importância a existência de um sistema de avaliação na educação a distância com o objetivo de aferir a qualidade do curso. Para MAGALHÃES \& SCHIEL (1997), o processo de avaliação é fundamental para o controle de qualidade na educação a distância.

MAGALHÃES (1997) defende que a falta de um controle de qualidade nos sistemas presenciais e a distância representa uma das grandes falhas do processo educacional.

Por fim, vale esclarecer que as questões discutidas no item 4.1 deste capítulo também são do interesse da educação a distância, já que essa forma de educação também pode ser sustentada pelos quatro ingredientes que foram discutidos: a tecnologia, o software educativo, o aluno e o professor. Esclarecer esse fato evita a necessidade de rediscutir aqui todas aquelas questões.

\subsection{2 - PERSPECTIVAS}

Para TODOROV (1994), a educação a distância nasceu sob o signo da democratização do saber. Seu maior objetivo é criar condições de acesso à educação a todos aqueles que, por um motivo ou outro, não estejam sendo atendidos satisfatoriamente pelos meios tradicionais. Ao contrário do que muitos dizem, ela não cria a separação entre aluno e professor, mas sim busca reduzir as distâncias que a vida criou. Além da educação, ela pode ser utilizada para a capacitação e a aprendizagem de novas técnicas e procedimentos, permitindo a 
sobrevivência com autonomia e liberdade em um mundo complexo marcado pelo constante avanço tecnológico e pelas transformações cada vez mais rápidas em todas as esferas da sociedade.

Por suas características, pode-se enumerar as seguintes vantagens da educação a distância:

- reduz as barreiras de tempo, espaço e idade;

- respeita o ritmo de cada aluno;

- torna 0 processo de ensino-aprendizagem mais flexível e individualizado, graças à utilização de novos canais de comunicação e interação;

- permite acesso a um grande leque de cursos diversificados, desde profissionais até culturais, como cursos de arte, línguas, informática, música, etc;

- oferece alternativas flexíveis para profissionais que necessitam de treinamento e educação;

- oferece alternativas rápidas para a atualização de conhecimentos técnicos.

Atualmente ainda é possível encontrar muito preconceito e críticas em torno da educação a distância. Conforme afirmam CARVALHO, TRINDADE \& CASTRO (1999), a tradição do quadro-negro é um paradigma muito forte que vai demorar a ser quebrado. Assim, ainda é difícil convencer pais e professores que o aluno pode aprender por si próprio.

Para COSTA NETO (1999), muitos céticos ainda não acreditam que os métodos a distância, sem a presença física do professor, quando bem planejados e executados, podem produzir resultados iguais ou melhores que os das aulas presenciais. Segundo esse autor, isso é possível em função da mudança de paradigma instrucional que está embutida na adoção da educação a distância: nela os alunos devem aprender a aprender, sendo estimulados a buscar o conhecimento por conta própria muito mais que no sistema tradicional presencial.

GONÇALVES (1996) comenta que por meio do ensino tradicional as pessoas foram levadas a acreditar que só podiam aprender se alguém explicasse e desenvolvesse, em sala de aula ou fora dela, os conteúdos a serem aprendidos. "Como alunos, esperávamos que um docente nos ensinasse por acreditarmos que 
só a partir disso teríamos condições de aprender" (p.5). Para essa autora, na educação a distância as coisas acontecem de um modo diferente: "espera-se e cria-se condições para que o aluno perceba que com materiais adequados e com boas orientações ele pode, e deve, construir a própria aprendizagem de forma autônoma e independente" (p.5).

Conscientemente ou não, ainda é um pensamento comum desconsiderar a possibilidade de coexistência entre a educação a distância e a educação tradicional presencial. Muitos acreditam que adotar a primeira significa abandonar a segunda. De acordo com NUNES (1994), a educação a distância não pode ser vista como substitutiva da educação tradicional presencial. Elas são duas modalidades do mesmo processo, portanto, não concorrem entre si. Para MORAN (1994), as duas formas de educação são necessárias, possuem vantagens e desvantagens e, quando combinadas, oferecem melhores resultados.

Porém, conforme afirma NUNES (1994), quando se pretende desenvolver um programa de educação a distância em uma instituição presencial, não se pode conduzi-lo em conflito com a cultura existente. Ao contrário, é preciso adequá-lo a ela, estabelecendo mecanismos de cooperação e convívio entre as duas modalidades. Pode-se com isso, inclusive, possibilitar que a educação a distância contribua para a melhoria da educação presencial.

GONÇALVES (1996) comenta que ainda é comum a secundarização da educação a distância diante da presencial. Nas estruturas organizacionais das instituições que adotam as duas modalidades, é comum encontrar a educação a distância em patamares hierárquicos inferiores, subordinada a vários níveis decisórios. A priorização do ensino presencial em qualquer decisão envolvendo a aprovação de projetos, alocação de recursos e investimentos, é facilmente perceptível.

Segundo essa autora, cabe em tais instituições a realização de esforços que resultem na percepção da educação a distância e da presencial como partes integrantes do mesmo projeto educacional, e não partes isoladas que competem entre si. O importante é que as duas modalidades possam contribuir para ampliar, em qualidade e quantidade, as oportunidades educacionais que a instituição coloca à disposição da sociedade. Assim, é necessário um gerenciamento único das ações que envolvem as duas formas de educação, além do envolvimento de todos os agentes educacionais, sejam eles administradores, docentes ou técnicos 
que apóiam o processo educacional.

Infelizmente, ainda é possível sentir que as críticas e preconceitos em torno da educação a distância são maiores aqui no Brasil do que em vários países cuja situação econômica e educacional é igual ou pior. Esse fato pode ser visto de certa forma como uma grande ironia, já que, por suas características, dificuldades, problemas educacionais, tamanho da população e área geográfica, o Brasil é um dos países do mundo que mais benefícios poderia conquistar com a educação a distância. Enquanto isso ocorre, os países mais desenvolvidos avançam em novas formas e métodos de educação a distância, conquistando resultados que garantem mais investimentos do governo e da iniciativa privada.

Entre outros motivos, muitos professores ainda se sentem inseguros com a educação a distância pelo fato dela:

- estar baseada em uma nova concepção do processo de ensinoaprendizagem;

- ser mais desafiadora (considerando que as dificuldades e exigências ainda não são bem conhecidas, ao contrário da educação presencial);

- ter pouca legitimidade enquanto modalidade de educação de qualidade;

- representar um risco, já que poderá substituí-los por uma máquina.

Pode-se notar que, basicamente, muitas dúvidas, críticas ou inseguranças não estão fundamentadas por hipóteses que refletem um conhecimento real e amplo sobre o assunto. GONÇALVES (1996) entende que algumas críticas envolvendo a educação a distância residem numa percepção restrita de suas possibilidades operacionais.

Em qualquer processo democrático, as discussões e críticas são bemvindas. São até necessárias nas situações onde o objeto de discussão pode ser responsável por transformações ou alterações drásticas no ambiente no qual será inserido. No entanto, quando há sinais claros ou potenciais que o objeto promoverá as mudanças esperadas, atingindo os objetivos propostos, as discussões e críticas devem avançar além do nível do pessimismo ou preconceito iniciais.

Em muitos casos, é possível observar que a discussão envolvendo a educação a distância no Brasil ainda não ultrapassou esse nível, revelando que 
algumas pessoas ainda não analisam essa forma de educação sob a perspectiva da melhoria de certas condições de vida da sociedade e no contexto amplo de todo o sistema educacional.

Felizmente, já é possível sentir uma certa mobilização por parte de alguns especialistas, setores da sociedade e do próprio governo no sentido de divulgar a educação a distância como uma possibilidade educacional real e imprescindível para a nação. Essa mobilização é decorrente do conhecimento de algumas vantagens potenciais que a educação a distância poderia trazer para a sociedade brasileira. Entre essas vantagens, estão:

- ampliar as possibilidades de acesso à educação, em todos os níveis;

- atender a um grande número de alunos a um custo potencialmente reduzido;

- atender aqueles que, por um motivo ou outro, não tiveram acesso à educação formal e, já vinculados ao mercado de trabalho, precisam de um ritmo próprio de estudo, por falta de horário flexível disponível;

- desenvolvimento de programas de capacitação de recursos humanos, reciclagem de mão de obra e aperfeiçoamento individual para empresas, escolas, governo, etc. Os interessados podem ser tanto profissionais já inseridos no mercado de trabalho, quanto pessoas que estão sem ocupação no momento (desempregados, por exemplo).

A Lei $n^{\circ}$ 9.394, de 20 de dezembro de 1996 (que estabelece as diretrizes e bases da educação nacional), mais do que tirar a educação a distância da clandestinidade, representou um importante passo dado pelo governo no sentido de incentivar essa forma de educação. No entanto, é preciso que esse incentivo sob forma de lei não se resuma apenas a uma carta de boas intenções, mas que seja traduzido em ações concretas por parte do governo.

Segundo COSTA NETO (1999), as grandes distâncias e enormes carências educacionais, torna a educação a distância uma questão indiscutivelmente estratégica para o Brasil, pelas possibilidades que oferece de poder encurtar 0 caminho que separa o país do mundo desenvolvido. MORAN (1994) defende que é preciso descobrir as formas de educação a distância mais adequadas para a realidade nacional, junto com novas formas de educação presencial. 
Para NUNES (1994), a educação a distância pode contribuir de forma significativa para o desenvolvimento de um país, principalmente em uma sociedade com as características brasileiras, onde o sistema educacional não consegue desenvolver as múltiplas ações que a cidadania requer. Esse autor enumera e descreve alguns campos onde a educação a distância pode ser empregada no Brasil:

\section{Democratização do saber}

Passo fundamental nesse sentido é dado pela educação formal. No entanto, em um mundo com tantas mudanças e transformações, o acesso às informações sistematizadas e formas de capacitação para a tomada de decisões independentes e autônomas, necessita de ações que vão além das fronteiras da educação formal. Assim, no campo da educação não formal e informal, a educação a distância pode desempenhar múltiplos papéis, indo desde a atualização de conhecimentos específicos, até a formação profissional.

Em vez de substituta, a educação a distância pode ser utilizada como forma complementar de educação, atualizando conhecimentos e conceitos, mostrando aos profissionais os avanços promovidos em suas áreas específicas e, principalmente, gerando a milhões de cidadãos o acesso aos conhecimentos acumulados pela humanidade.

\section{Formação e capacitação profissional}

Tanto na formação profissional básica quanto na formação universitária, a educação a distância tem demonstrado ser uma modalidade de educação com grandes potencialidades, principalmente por ser um meio de educação de massa.

A dinâmica própria das transformações tecnológicas atuais, a sofisticação e o requerimento de agilidade no trato das informações, além da necessária qualificação para o relacionamento com um mercado consumidor cada vez mais exigente, fará com que as grandes empresas sejam levadas a adotar procedimentos de formação, qualificação e capacitação de pessoal que atendam a requisitos de celeridade e custo. A educação a distância pode servir a essas empresas, já que permite envolver um grande número de pessoas ao mesmo tempo e em regiões distantes, a um custo reduzido. 
A educação a distância também pode servir às empresas especializadas no treinamento de pessoal, não somente por introduzir ganhos de eficiência e eficácia, mas também por reduzir custos relativos, quando se tratar de processos de treinamento de contingentes numerosos de alunos, além de elevar a qualidade, através de processos de definição de conteúdo elaborados por equipes multidisciplinares altamente qualificadas a custo relativamente baixo.

No caso dos serviços públicos, já é possível observar a necessidade de formação e atualização profissional de servidores em quantidades e com características de dispersão geográfica que irão exigir a implantação de sistemas de educação a distância.

Também é importante observar que as oportunidades geradas pela educação a distância não estão restritas apenas aos profissionais que já estão no mercado de trabalho formal, mas também no caso de desempregados. A educação a distância também pode ser empregada para a formação e atualização de contingentes populacionais com pouca escolaridade mas com grande experiência de vida, adaptando-se às diferentes realidades das pessoas e buscando transformá-las em cidadãos ativos da sociedade.

\section{Capacitação e atualização de professores}

Apesar de inserir-se no caso anterior, essa questão merece destaque no caso brasileiro, devido às características dos quadros de professores, notadamente aqueles responsáveis pela educação de jovens e crianças que se encontram nas escolas tentando concluir o ensino básico.

\section{Educação aberta e continuada}

A educação a distância possibilita a proliferação de experiências de grande alcance social, para a formação cultural da nacionalidade, permitindo o acesso à educação a grandes contingentes afastados das instituições formais de ensino, ou que têm dificuldades de acesso. Assim, cursos de saúde, ecologia, tecnologia e artes podem ser veículos importantes para a integração social de grandes parcelas da população.

A educação a distância poderia ser resultado de parcerias realizadas entre Estado e sociedade, visando a disseminação de conhecimentos básicos para a 
prevenção de doenças, para o conhecimento de técnicas e métodos de higiene e saneamento comunitário, organização social urbana, etc.

\section{Educacão para a cidadania}

Um conjunto significativo de ações educativas pode ser realizado por meio da educação a distância, transformando processos cívicos obrigatórios por lei em processos realmente participativos e conscientes.

Temas fundamentais da existência contemporânea da sociedade podem e devem ser tratados através de cursos ou meios educativos sistemáticos, capazes de elevar o nível de participação responsável da sociedade no processo de construção da nacionalidade. A integração das organizações da sociedade civil com movimentos populares certamente produzirá frutos fundamentais, apoiados por procedimentos educativos a distância. Nesse caso inserem-se os cursos dirigidos a segmentos definidos da sociedade, como cursos de formação sindical, cursos de cidadania, organização comunitária, formação política, entre outros.

Apesar da sua possibilidade de aplicação em tantas áreas diferentes, a educação a distância nem sempre alcança os resultados esperados. Assim, para que as decepções sejam evitadas, é preciso investir mais na formação dos professores e monitores, exigir vontade política, obter mais investimentos e superar o preconceito que enxerga a educação a distância como de segunda classe.

Segundo MORAN (1994), ainda existe pouca gente com experiência em educação a distância no Brasil. Por ser complexa, essa modalidade de educação precisa de pessoas com mentalidade aberta e que se disponham a experimentar e avaliar novas formas de ensino-aprendizagem.

Também há relativamente pouca pesquisa sendo gerada no Brasil, como conseqüência direta de haver poucas pessoas trabalhando na área. Com relação às pesquisas geradas em outros países, elas nem sempre podem ser aproveitadas dentro do contexto nacional. Mas com o tempo, conforme novas experiências começarem a surgir, reflexos atingirão a literatura e a própria opinião pública, o que fatalmente contribuirá para quebrar as barreiras discriminatórias existentes, permitindo que a educação a distância avance e alcance seus objetivos. 
Por fim, é importante não encarar a educação a distância como a solução para todos os problemas educacionais brasileiros, já que ela está inserida em contextos mais amplos que também interferem na qualidade da educação nacional: o contexto político, o econômico, o social, além do próprio contexto educacional. 


\section{Capítulo 5 - Um Ambiente de Aprendizagem na Web}

Como uma aplicação prática deste trabalho, foi desenvolvido um ambiente de aprendizagem na Web, através do software WebCT. O domínio de aplicação escolhido para esse ambiente foi a disciplina SEM-387 "Planejamento e Controle da Produção I", do curso de Engenharia de Produção da Escola de Engenharia de São Carlos, da Universidade de São Paulo.

A criação desse ambiente teve como principal objetivo reunir em uma aplicação conhecimentos resultantes da análise da utilização do computador como instrumento de melhoria do processo de ensino-aprendizagem, proposta maior deste trabalho. Assim, ele representa uma tentativa de colocar em prática algumas questões, experiências e conceitos que foram discutidos.

O ambiente de aprendizagem desenvolvido está inserido dentro do conceito de software educativo utilizado neste trabalho.

\section{1 - ESCOLHA DA DISCIPLINA}

O Planejamento e Controle da Produção tem uma importância reconhecida na formação e atuação profissional do Engenheiro de Produção. Segundo BELHOT (1993, p.673), "a matéria Planejamento e Controle da Produção (PCP) tem sido objeto de publicação nas mais diferentes fontes, assumindo as mais variadas formas e recebendo os mais diversos tratamentos. A quantidade de material disponível sobre o assunto, demonstra a incontestável relevância do PCP no contexto da produção industrial e na área de serviços. Em linhas gerais, essa importância vem do fato de ser em essência um sistema de informações que orienta as decisões da empresa, para que ela atinja determinados objetivos. Esses 
objetivos referem-se ao atendimento dos prazos, à obtenção de mínimos custos e à máxima utilização dos recursos produtivos, entre outros".

No curso de Engenharia de Produção da Escola de Engenharia de São Carlos, a matéria Planejamento e Controle da Produção é coberta por três disciplinas: SEM-361 "Sistemas de Produção", SEM-387 "Planejamento e Controle da Produção I" e SEM-336 "Planejamento e Controle da Produção II". A primeira disciplina é informativa e cobre conceitos básicos de sistemas de produção e os principais processos decisórios. A segunda é instrumental e trata dos métodos e técnicas que dão suporte às decisões de previsão, estoque, planejamento, programação e controle da produção. A terceira discute as novas formas de organização da produção, envolvendo conceitos de MRP ("Material Requirements Planning"), JIT (“Just in Time") e integração da manufatura, entre outros.

A complexidade implícita da disciplina SEM-387 transfere particular dificuldade ao processo de ensino-aprendizagem. Além disso, o número de publicações disponíveis sobre o assunto abordado pela disciplina, apesar de realçar sua importância, gera um excesso de informações, na medida em que permite a utilização de várias abordagens, métodos e técnicas que dependem da natureza e combinação dos elementos que caracterizam os sistemas de produção (produtos, processos, equipamentos e mão-de-obra).

Essa complexidade implícita e esse excesso de informações, aliados à sua importância fundamental para que o aluno possa compreender os conceitos, técnicas e métodos envolvidos com o PCP, levaram à escolha dessa disciplina como domínio de aplicação da parte prática deste trabalho.

Dentro da disciplina, foram escolhidos alguns temas para serem abordados pelo ambiente de aprendizagem. Nessa escolha, levou-se em conta não apenas sua importância no contexto do Planejamento e Controle da Produção e da própria disciplina, mas procurou-se também selecionar temas complexos e dinâmicos que favorecessem a utilização da multimídia, do hipertexto e da hipermídia na forma de apresentação da informação ao usuário. Assim, foram selecionados três temas, englobando os seguintes assuntos:

- O Planejamento e Controle da Produção: o que é o PCP; qual a sua importância para a empresa; quais suas principais atividades e decisões; tipos de sistemas de produção existentes; localização do PCP dentro do contexto da Administração da Produção; 
- Previsão de Vendas: importância; principais métodos de previsão e predição existentes; erros de previsão; como escolher o melhor método;

- Planejamento e Controle de Estoques: definição de estoque; qual a importância do estoque; tipos de estoque; principais decisões envolvidas com o gerenciamento do estoque.

A figura 8 ilustra as três disciplinas que cobrem a matéria Planejamento e Controle da Produção na EESC-USP, bem como os temas que foram escolhidos para serem abordados pelo ambiente de aprendizagem.

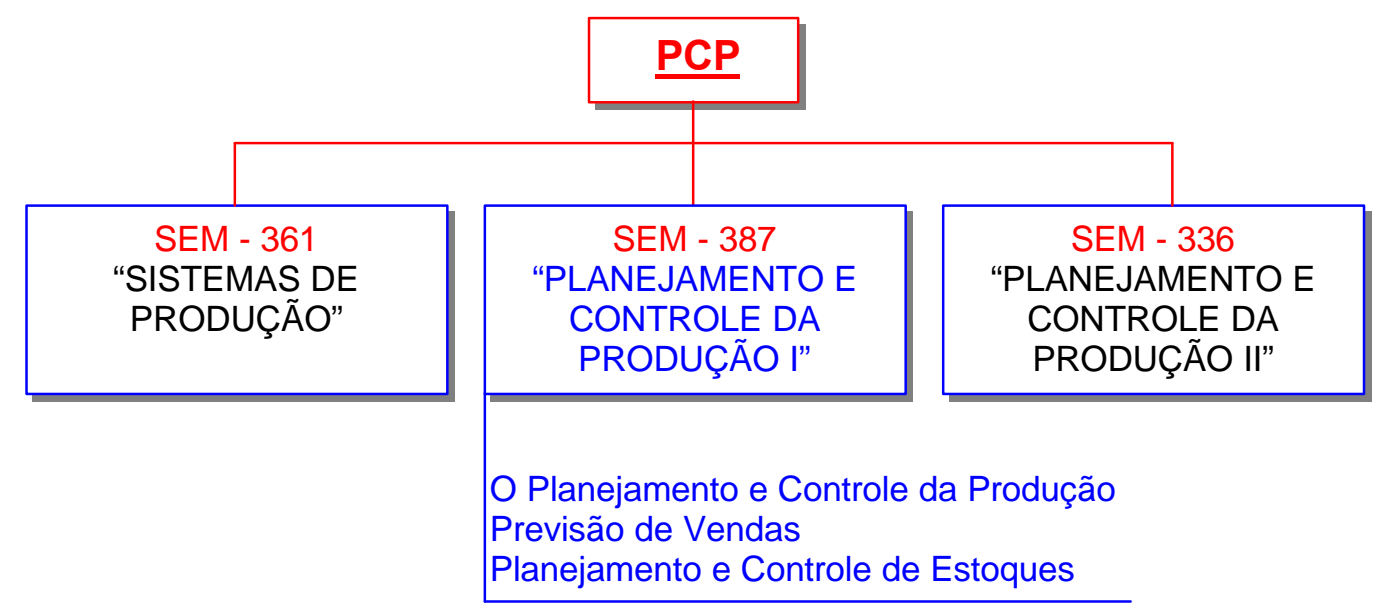

FIGURA 8 - As três disciplinas da matéria Planejamento e Controle da Produção e os temas escolhidos da disciplina SEM-387

\section{2 - DESCRIÇÃO DO AMBIENTE DE APRENDIZAGEM DESENVOLVIDO}

O desenvolvimento do ambiente de aprendizagem foi dividido em algumas etapas, visando o cumprimento dos prazos e objetivos propostos. As etapas são as seguintes:

1. Determinação dos objetivos: determinação dos objetivos do ambiente de aprendizagem; determinação do público-alvo; necessidades que serão satisfeitas com o seu desenvolvimento;

2. Definição do domínio de aplicação: escolha da disciplina; definição e preparação dos assuntos de PCP que o ambiente abordará; 
3. Seleção dos recursos necessários: seleção de softwares e hardwares que serão utilizados no desenvolvimento;

4. Planejamento detalhado do ambiente: definição das ferramentas e recursos do WebCT que serão disponibilizados ao usuário; definição da estrutura completa do ambiente; definição da interface com o usuário; definição do nível de interatividade; preparação de todo o material que será incluído no ambiente; seleção dos softwares para produção de cada mídia;

5. Produção: implementação de tudo que foi definido na etapa anterior, incluindo toda a configuração do WebCT;

6. Teste de funcionamento e correções: realização de testes para verificar possíveis erros ou falhas de funcionamento do ambiente; alterações e correções; revisão ortográfica.

Antes de descrever o ambiente de aprendizagem, será apresentado de forma breve o software WebCT, no qual o ambiente foi desenvolvido.

\subsection{1 - O WEBCT}

O WebCT ("Web Course Tools") é um software para criação de ambientes de aprendizagem pela Internet desenvolvido pela University of British Columbia, do Canadá. Na USP de São Carlos, ele está concentrado em um servidor no Centro de Informática de São Carlos (CISC).

Algumas vantagens do WebCT:

- interface gráfica amigável (tanto para quem cria o ambiente, quanto para os alunos);

- conjunto de recursos e ferramentas que facilitam a aprendizagem, a colaboração e a comunicação.

O WebCT possui quatro classes de usuários:

- administrador;

- desenvolvedor; 
- monitores;

- alunos.

No WebCT, os ambientes de aprendizagem são chamados de cursos. Na USP, cada curso criado ou em desenvolvimento deve estar relacionado a alguma disciplina. Como exemplo óbvio, o ambiente de aprendizagem criado neste trabalho está relacionado à disciplina SEM-387.

O administrador é responsável por inicializar e apagar os cursos, além de outras funções administrativas e de apoio (na USP de São Carlos, o administrador é um funcionário do CISC). O desenvolvedor (ou designer) é responsável pela criação do curso, ou seja: desenvolve seu conteúdo, disponibiliza as ferramentas, cria provas, administra as contas dos alunos, acompanha seus desempenhos e frequências. O desenvolvedor geralmente é o docente responsável pela disciplina que o curso do WebCT irá apoiar (evidentemente, outras pessoas autorizadas pelo professor podem assumir essa tarefa, como aconteceu no caso deste trabalho). Os monitores possuem os mesmos privilégios que os alunos, além de terem acesso a recursos adicionais que os últimos não possuem.

Quando há o interesse de um professor desenvolver um curso através do WebCT, com o objetivo de apoiar alguma disciplina sob sua responsabilidade, ele contata o administrador no CISC. O administrador, por sua vez, disponibiliza uma área no WebCT para que o professor possa criar seu curso. Enquanto estiver sendo criando, o curso permanecerá em uma área do WebCT chamada de "cursos em preparação". Depois de pronto, o professor contata novamente o administrador para que ele possa colocá-lo em uma área onde estão os cursos prontos. O professor pode, então, criar as contas dos monitores e alunos, habilitando-os a utilizarem o curso. O desenvolvedor também pode modificar o curso mais tarde, quando e como quiser.

Tanto a construção do curso quanto o acesso dos alunos ou monitores são realizados remotamente pela Internet. A página inicial do WebCT na USP de São Carlos está mostrada na figura 9. Ela é acessada por meio de qualquer navegador da Web através do endereço: http://webct.cisc.sc.usp.br:8900/. Ao clicar sobre o link "lista de cursos", mostrado na figura 9, o usuário será levado para a página mostrada na figura 10, onde existirão alguns links. 


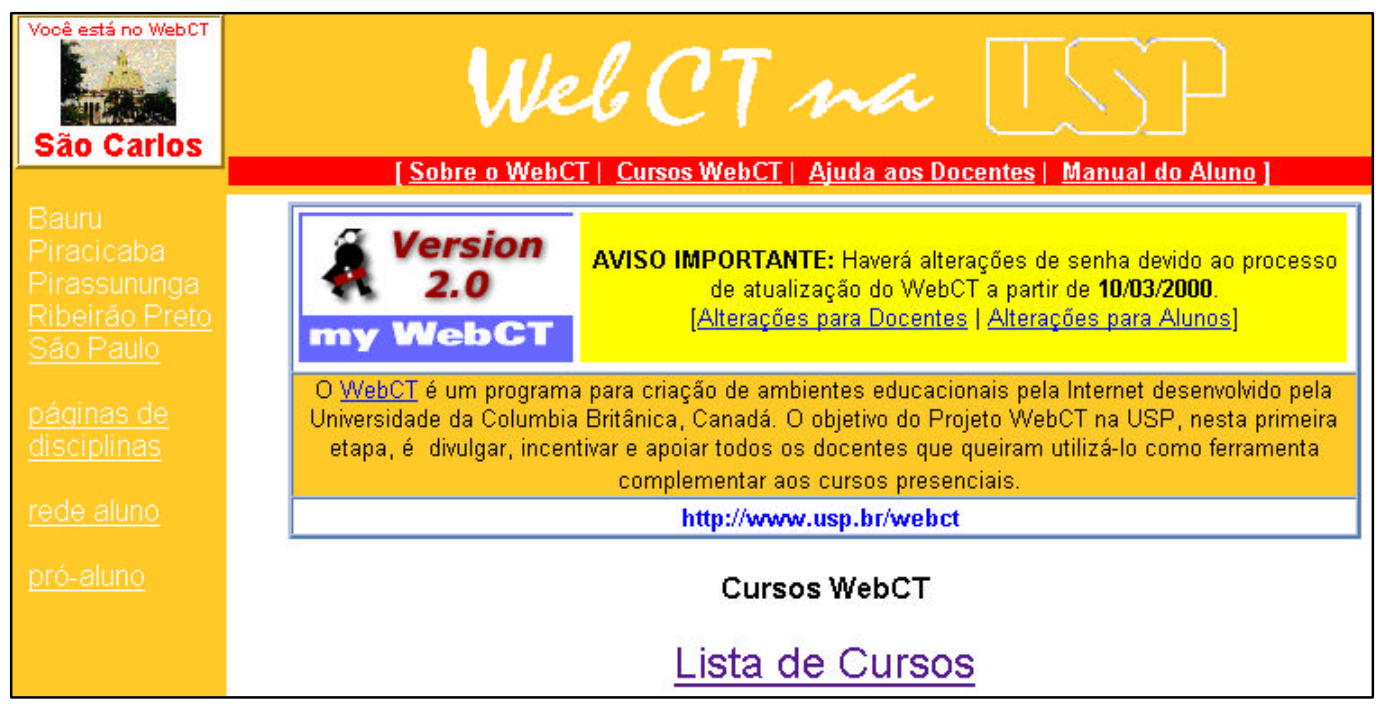

FIGURA 9 - Página inicial do WebCT

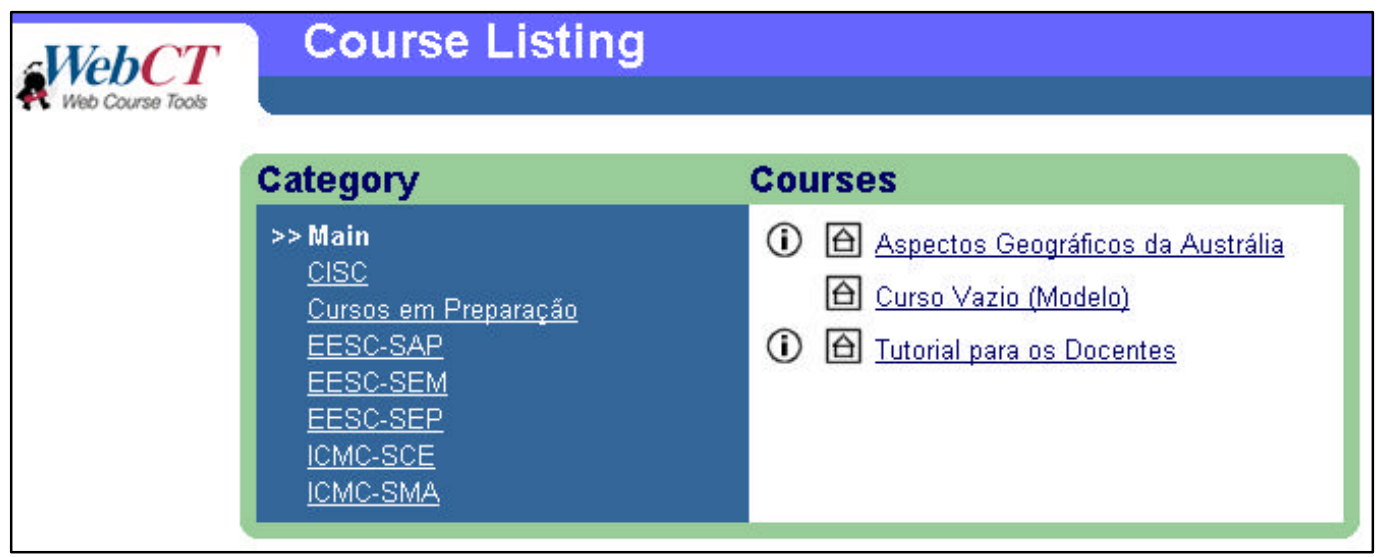

FIGURA 10 - Página do WebCT com links para as listas de cursos

No servidor do WebCT, os cursos estão divididos em grupos. Conforme esclarecido anteriormente, se o curso procurado ainda não estiver pronto, o usuário deverá clicar sobre o link "cursos em preparação" (veja a figura 10), que leva até a lista de cursos que ainda estão sendo desenvolvidos. Em caso contrário, ele deverá clicar em algum dos links que levam até os cursos prontos ("EESC-SEM", por exemplo, leva até a lista de cursos prontos do Departamento de Engenharia Mecânica). Clicando nos links corretos, o usuário chegará até uma lista onde haverá um link para o curso desejado. Como exemplo, a figura 11 mostra o link que leva até o curso desenvolvido neste trabalho. O link tem sempre o nome da 
disciplina apoiada pelo curso. Existe uma forma mais fácil de acessar um curso no WebCT, mas isso será explicado no próximo item do capítulo.

\section{(i) S S SEM 387 - Planejamento e Controle da Producao I}

FIGURA 11 - Link para o ambiente desenvolvido neste trabalho

A figura 11 mostra três ícones ao lado do nome do curso (disciplina). Para entrar no curso, tanto o desenvolvedor quanto os alunos e monitores devem clicar sobre o título do curso ou sobre o ícone em forma de casa. Para permitir a entrada, o WebCT irá pedir um nome (login) e uma senha (password).

O ícone em forma de "i" leva até uma página de boas-vindas (conhecida como Welcome Page), que fornece informações gerais sobre o curso. Pode ser acessada por qualquer um sem a necessidade de senha. $O$ ícone em forma de chave permite que visitantes (guests) entrem no curso. Quando um visitante clica sobre esse ícone, o WebCT solicita seus dados e cria sua conta individual. O visitante está, hierarquicamente, no mesmo nível que o aluno. O ícone que leva até a página de boas-vindas e o que cria a conta para visitantes são opcionais, o que significa que podem ser desabilitados pelo desenvolvedor.

O WebCT sabe qual a classe de usuário que está solicitando sua entrada no curso através da password e do login fornecidos. A visão que os alunos ou monitores têm do curso é bem diferente daquela que tem o desenvolvedor. A figura 12 mostra uma mesma página do curso vista pelos alunos e pelo desenvolvedor.

Por ser responsável pela configuração do curso, escolha dos recursos e ferramentas que serão disponibilizadas, criação das provas e testes, criação das contas e acompanhamento dos alunos e monitores, o desenvolvedor tem acesso a um conjunto de recursos próprios do WebCT que permitem a ele um controle e um gerenciamento total do curso. Evidentemente, tudo é transparente para o aluno, o que explica as diferentes visões do curso.

Por exemplo, um dos recursos disponíveis para o desenvolvedor gerenciar seu curso é o "Course Management", que possui as seguintes funções:

- Student Management: permite ao professor ver, compilar e editar informações sobre os alunos, incluir novos alunos, etc; 
- Grader Management: permite incluir, retirar ou editar as notas dos alunos;

- Student Tracking: fornece informações sobre o progresso do aluno, ou seja, quais as páginas do curso ele já visitou, quais ferramentas foram usadas, etc;

- Page Tracking: fornece informações estatísticas sobre as páginas do curso, permitindo ao professor conhecer quais são as mais visitadas, quais os alunos estão gastando mais tempo nas visitas, etc;

- Presentations: permite que os alunos coloquem seus próprios materiais (arquivos) no servidor do WebCT;

- Course Functions: permite a criação de arquivos de segurança do curso.

A figura 13 mostra uma página do Course Management.

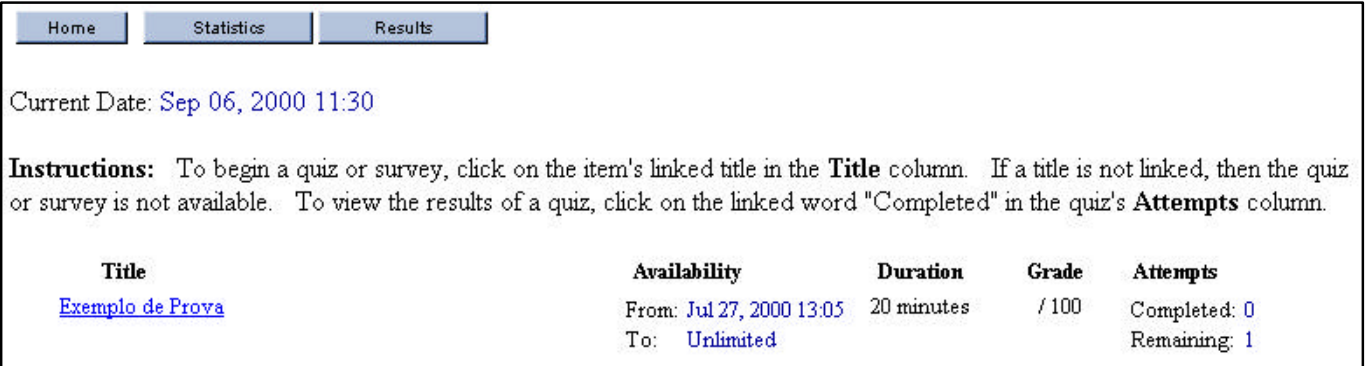

(visão aluno)

\begin{tabular}{|c|c|c|c|c|c|c|}
\hline \multicolumn{7}{|c|}{$\begin{array}{l}\text { The Quiz and Survey functions allow you to create online quizzes and surveys that can be marked or tabulated by the computer. Click } \\
\text { Questions to access the Question Database, which allows you to create, modify, and delete questions. To create a new quiz or survey, click } \\
\text { Add Quiz or Add Survey. To modify a quiz or survey, and to add questions to it, click its name. To view or regrade a submitted quiz or survey } \\
\text { click the appropriate Submissions hyperlink. Click the Details hyperlink to view the results for all the submissions for a quiz or survey. Click } \\
\text { the Reports or Summary hyperlinks to get detailed statistics for a quiz. To view the results for a quiz or survey, click the appropriate } \\
\text { hyperlink in the Results column. To change the appearance of the page, click Customize. Click Add Label to add a title for grouping and } \\
\text { organizing quizzes and surveys. To reposition an item, select the radio button for the item and click one of organization buttons on the right } \\
\text { of the toolbar. To erase an item, select its radio button and click Delete. }\end{array}$} \\
\hline \multicolumn{7}{|l|}{ Current date: Sep 06,2000 11:20 } \\
\hline Title & & & Availability & Duration & Mark & Results \\
\hline O Q Exemplo de Prova & & & $\begin{array}{l}\text { From: Jul 27, } 200013: 05 \\
\text { To: Unlimited }\end{array}$ & $20 \min$ & 100 & $\begin{array}{l}\text { [Submissions] [Detai] } \\
\text { Reports] [Summary] }\end{array}$ \\
\hline \multirow{2}{*}{ Home Quiz: } & Questions & Customize & Delete & Up 5 & $U_{p}$ & Indent \\
\hline & Add Quiz & Add Sunvey & Add Label & Down 5 & Down & Unindent \\
\hline
\end{tabular}

(visão desenvolvedor)

FIGURA 12 - A mesma página na visão dos alunos e do desenvolvedor 


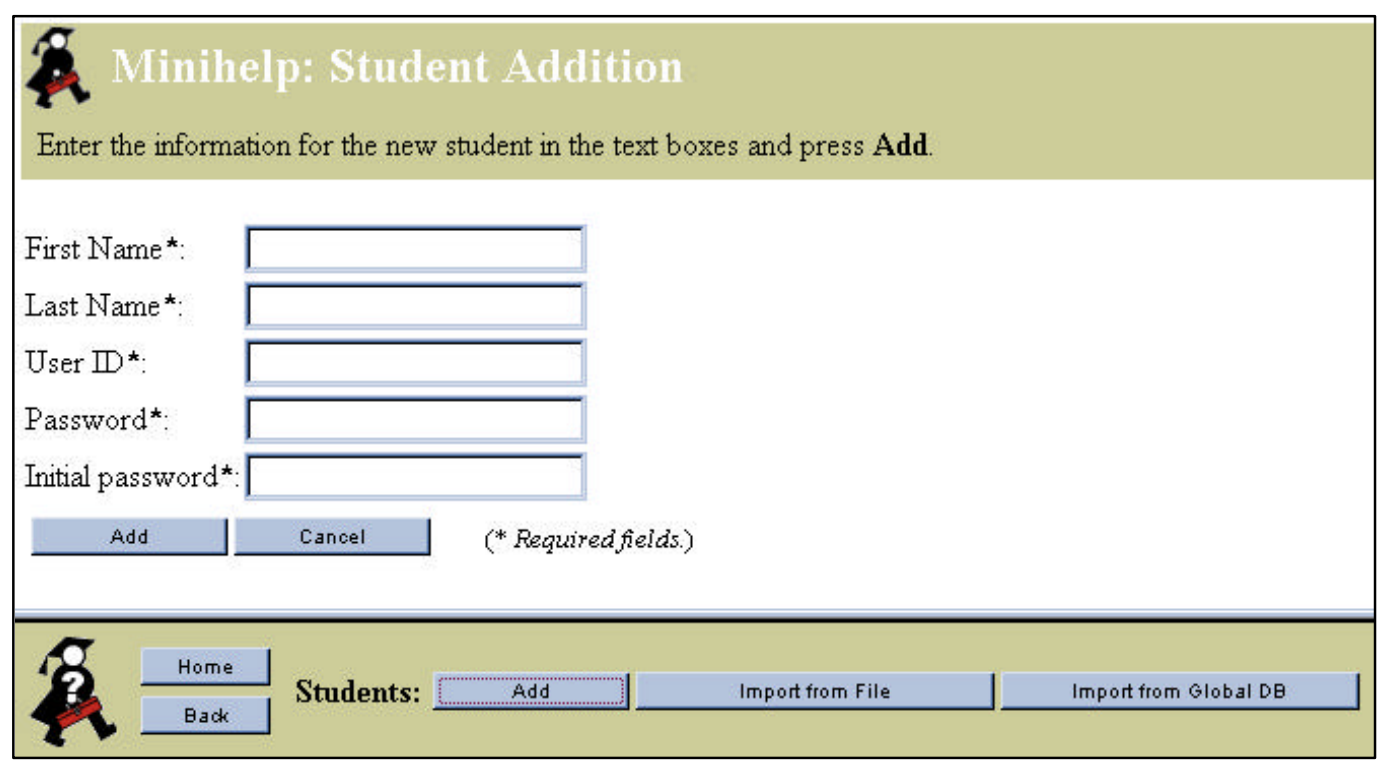

FIGURA 13 - Página do Course Management

O WebCT possui um conjunto de ferramentas que podem ser usadas pelos alunos e professor. O desenvolvedor pode habilitá-las ou não, baseado em sua vontade, objetivo do seu curso, etc. Cada ferramenta é representada por um ícone, cujo formato pode variar dependendo da escolha ou configuração que foi adotada pelo desenvolvedor. $O$ desenvolvedor tem uma certa flexibilidade para escolher 0 local do curso onde disponibilizará uma dada ferramenta. Algumas das principais ferramentas do WebCT estão descritas resumidamente na tabela 3.

Além das ferramentas, o WebCT possui também vários outros recursos que estão à disposição do desenvolvedor. Alguns existem em todos os cursos, outros são opcionais, podendo estar habilitados ou não. O WebCT também permite que sejam inseridos no curso materiais externos, como páginas HTML, figuras, arquivos multimídia, etc.

O WebCT é bastante simples de usar, seja por alunos, seja por quem esteja construindo o curso. No caso do desenvolvedor, os recursos e funções disponíveis facilitam muito o trabalho. Além disso, existem arquivos de ajuda em todas as páginas e para todos os recursos. Talvez a maior dificuldade na criação de um curso não seja o WebCT em si, mas a preparação do material externo que será incluído no curso. 
TABELA 3 - Algumas das principais ferramentas do WebCT

\begin{tabular}{|c|c|}
\hline FERRAMENTA & DESCRICÃO \\
\hline Mail & Correio eletrônico intemo disponível para os alunos cadastrados no curso. \\
\hline Bulletins & $\begin{array}{l}\text { Pemite que os usuários do curso enviem mensagens com comentánios, sugestões ou dúvidas } \\
\text { sobre o conteúdo do curso, sobre a disciplina ou qualquer assunto que mereça alguma } \\
\text { discussão. As mensagens enviadas são agnupadas por assunto. No caso da mensagem } \\
\text { representar uma dúvida de algum aluno, qualquer usuário pode respondêla. As mensagens } \\
\text { podem ser públicas (todos têm acesso) ou privadas (apenas as pessoas escolhidas pelo autor } \\
\text { damensagem têm acesso). }\end{array}$ \\
\hline Chat & $\begin{array}{l}\text { Fomece salas para conversas on-line. Existem seis salas: quatro de propósitos gerais, uma } \\
\text { sobre o curso e outra envolvendo todos os cursos. }\end{array}$ \\
\hline Dropbox & $\begin{array}{l}\text { Pemite que o professor envie tarefas aos alunos. Os alunos podem, então, enviar as tarefas } \\
\text { resolvidas de volta ao professor via senvidor do WebCT. }\end{array}$ \\
\hline Quiz & $\begin{array}{l}\text { Pemite que o professor crie e administre testes para seus alunos. O professor pode configurar } \\
\text { qual o período de tempo que o teste ficará disponível, quanto tempo o aluno terá para resolvêlo, } \\
\text { entre outras coisas. Dependendo dos tipos de questóes incluídas, os testes podem ser } \\
\text { resolvidos automaticamente pelo WebCT. Existem dois tipos de testes: quiz e survey. Ao } \\
\text { contrário da quiz, o resultado de uma survey é anônimo (é possível saber quem já resolveu e } \\
\text { enviou, porém não é possível conhecer os resultados individuais dos alunos). Existem, para os } \\
\text { dois tipos de testes, fermamentas estatísticas que analisam os resultados dos alunos. }\end{array}$ \\
\hline Self-Test & $\begin{array}{l}\text { Pemite a criação de questões de múltipla escollha para serem respondidas pelo aluno. A } \\
\text { correção é feita automaticamente pelo WebCT e apresentada ao aluno. Só o próprio aluno } \\
\text { recebe o resultado. }\end{array}$ \\
\hline Calendar & $\begin{array}{l}\text { Fomece um meio rápido e fácil para que professor e alunos divulguem eventos do curso. As } \\
\text { informaçōes podem ser privadas (apenas o autor tem acesso) ou públicas. }\end{array}$ \\
\hline Whiteboard & $\begin{array}{l}\text { Permite que uma ferramenta de desenho seja dividida pelos alunos ao mesmo tempo. Assim, } \\
\text { se um objeto estiver sendo desenhado por algum aluno, todos que estiverem utilzando a } \\
\text { ferramenta naquele momento poderão modificáto. É útil para discussões em gnupo onde } \\
\text { desenhos ou diagramas são necessários. }\end{array}$ \\
\hline Image Database & $\begin{array}{l}\text { Pemite a criação de um banco de dados com imagens. Fomece também um mecanismo de } \\
\text { busca (search) para faciltar a localização das imagens no banco de dados. }\end{array}$ \\
\hline Home Pages & $\begin{array}{l}\text { Disponibiliza uma área onde os alunos podem colocar suas páginas pessoais. Para aqueles } \\
\text { que ainda não possuem uma, essa ferramenta fomece um editor de páginas HTML }\end{array}$ \\
\hline Search & Permite que o aluno faça buscas de palavras ou termos no curso. \\
\hline My Grades & $\begin{array}{l}\text { Permite que os alunos vejam suas notas, tal como o resultado de uma quiz ou de alguma } \\
\text { tarefa. Cadaaluno só pode ver suas próprias notas. }\end{array}$ \\
\hline My Progress & Mostra ao aluno quais as páginas do curso que ele já visitou. \\
\hline Glossary & $\begin{array}{l}\text { Permite que seja criado um glossário com as palavras mais importantes contidas nas páginas } \\
\text { do curso. }\end{array}$ \\
\hline Index & $\begin{array}{l}\text { Pemite que seja criado um índice de palavras associado às páginas do curso. É organizado da } \\
\text { mesma forma que os índices encontrados nos livros. }\end{array}$ \\
\hline Goals & Pemite que o professor relacione metas de aprendizagem às páginas do curso. \\
\hline References & $\begin{array}{l}\text { Fomece ao professor um meio prático para indicar aos seus alunos fontes de informaçães } \\
\text { adicionais para as páginas do curso. As fontes podem ser de três tipos: livros, artigos ou } \\
\text { endereços URL }\end{array}$ \\
\hline My Notes & Pemite que os alunos façam anotações individuais relacionadas a uma página do curso. \\
\hline
\end{tabular}


O WebCT foi escolhido neste trabalho por estar disponível na USP de São Carlos, o que evitou a necessidade de compra do software e de licenças de uso, ou a necessidade de desenvolver um software do mesmo tipo (o que fugiria totalmente aos objetivos deste trabalho e do foco da Área de Engenharia de Produção). Além disso, ele preenche todas as necessidades e objetivos que foram propostos para o ambiente de aprendizagem. Em instituições acadêmicas ou no próprio mercado existem vários outros softwares do mesmo tipo. Alguns desses softwares: eWeb, AulaNet, LearningSpace, QuestWriter, TopClass, etc (veja por exemplo, SCAPIN, 1997).

\subsection{2 - O AMBIENTE DE APRENDIZAGEM}

Indo até o endereço http://webct.cisc.sc.usp.br:8900/, clicando sobre o link "lista de cursos" (mostrado anteriormente na figura 9) e depois escolhendo o link "EESC-SEP" (link para a lista de cursos da Área de Engenharia de Produção, que aparece na figura 10), o usuário irá encontrar o link para o curso que será descrito a seguir. Para entrar, ele deverá fornecer seu login e password após clicar sobre o título da disciplina ou em algum dos ícones mostrados anteriormente na figura 11. Neste item, assim como ocorreu no anterior, o termo curso será utilizado ao invés de ambiente de aprendizagem apenas para seguir a terminologia do WebCT (mas neste trabalho eles podem ser entendidos como sendo sinônimos).

A figura 14 mostra a página inicial do curso, conhecida no WebCT como Homepage. O desenvolvedor pode configurar essa página de acordo com a sua necessidade: pode incluir contador de acesso, colocar figuras, adicionar ou retirar ferramentas, etc (aliás, as principais páginas de um curso do WebCT podem ser personalizadas). A Homepage, além de ser a página inicial, serve também como ponto de referência para o usuário. Em quase todas as áreas e ferramentas do curso existe um link para ela (o link "home").

A figura 14 também mostra vários ícones que representam as ferramentas do WebCT que foram disponibilizadas para os alunos e professor. Entre elas: chat, dropbox, quiz, bulletins e calendar. As figuras 15 e 16 mostram as páginas de duas dessas ferramentas: chat e bulletins. 


\section{\begin{tabular}{c}
\hline SEM 387 \\
Planojamento e Controle da Produção I
\end{tabular}}

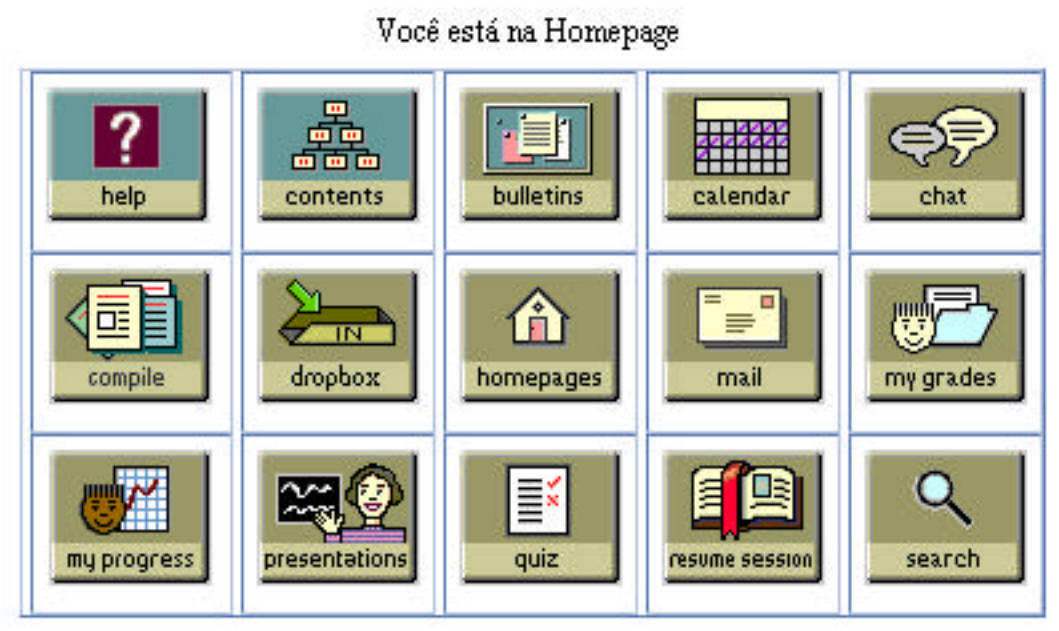

\section{6}

[my WebCT]

FIGURA 14 - Página inicial do curso da disciplina SEM-387

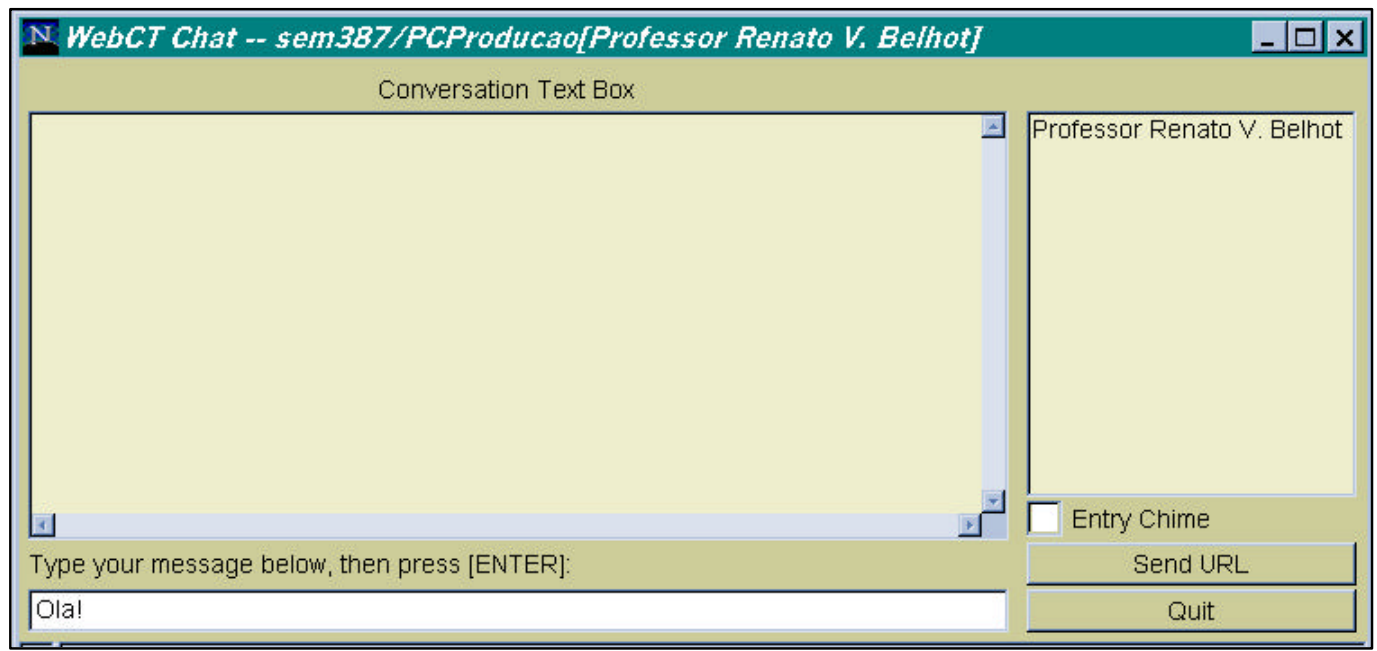

FIGURA 15 - Ferramenta chat 


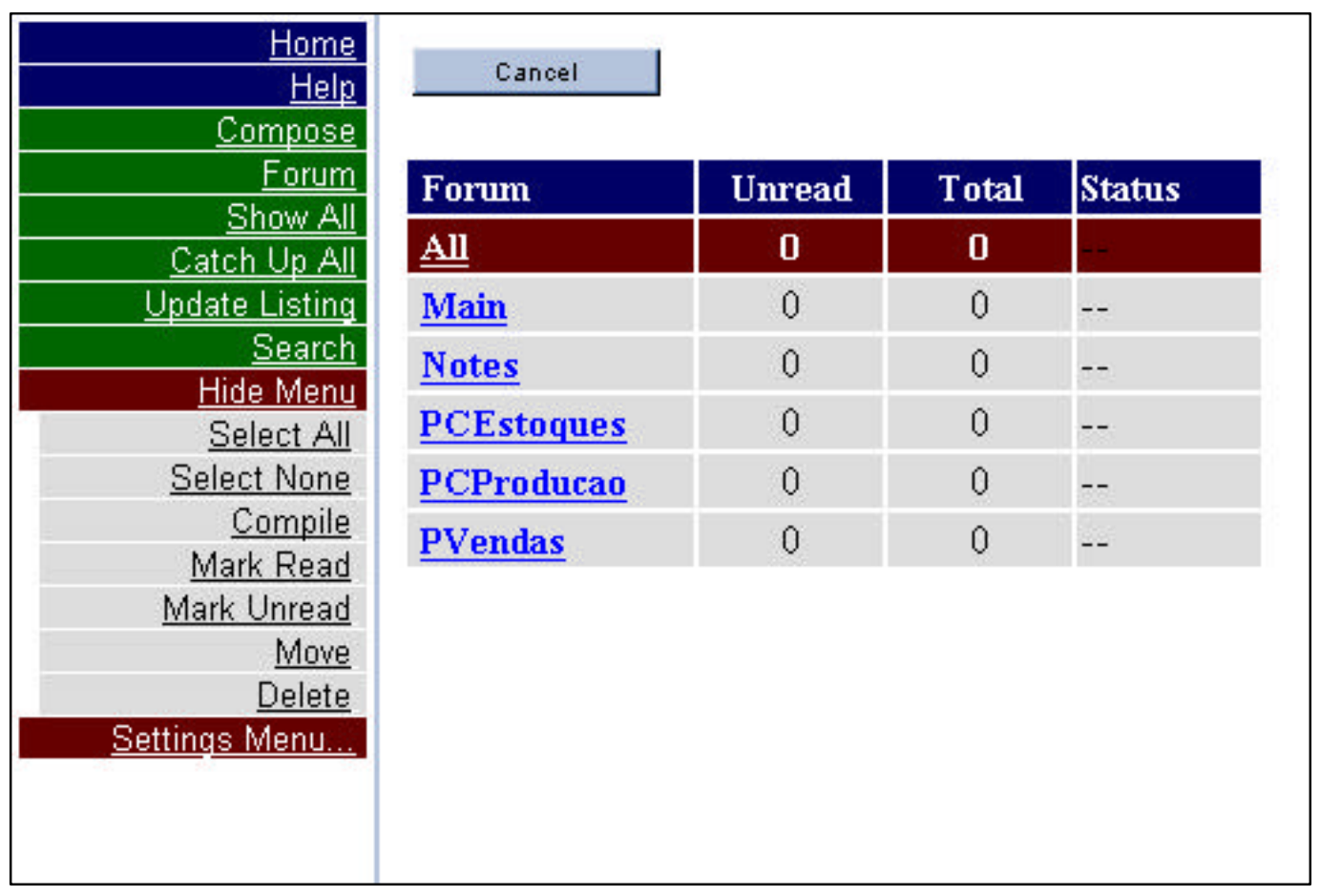

FIGURA 16 - Ferramenta bulletins

Para abrir qualquer ferramenta, o usuário deve clicar com o mouse sobre o ícone correspondente. Ainda que algumas ferramentas necessitem de uma explicação mais detalhada, de modo geral elas são bem intuitivas, favorecendo uma aprendizagem rápida por parte do aluno. Algumas delas servem a propósitos individuais, mas existem outras cuja grande vantagem e maior objetivo é facilitar a cooperação e a comunicação entre os alunos e o professor e entre os próprios alunos, como é caso do chat, dropbox, bulletins, mail, entre outras.

$\mathrm{Na}$ Homepage, logo abaixo dos ícones das ferramentas e do contador de acesso, existe um link para a My WebCT (o link aparece na figura 14), que é uma área privativa de cada usuário do WebCT, com links para todos os cursos em que ele está cadastrado, avisos vindos de cada um dos cursos (novos trabalhos e testes enviados pelo professor, por exemplo), mensagens do administrador do sistema, além de recursos personalizados. Na My WebCT o usuário também tem acesso ao site http://www.webct.com, que passou a ser um portal de educação a distância formada por comunidades de estudantes que utilizam o WebCT em todo o mundo.

Além da Homepage, é possível acessar a My WebCT a partir da página inicial do WebCT, que também possui um link para essa área (esse link aparece na figura 9). Aliás, esse é o meio mais rápido e fácil de entrar em um curso (evita ficar 
procurando o link do curso nas listas dos cursos prontos).

Todos os ícones mostrados na figura 14 são links para ferramentas do WebCT. As exceções são os ícones "help" e "contents", mostrados novamente na figura 17. O primeiro é um link para uma página de ajuda aos alunos, com informações sobre o WebCT, seus principais recursos e ferramentas.

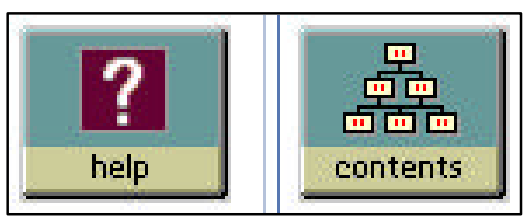

FIGURA 17 - Os links "help" e "contents" da Homepage

O segundo ícone, "contents", é um link para uma página separada do curso. Ela é semelhante à Homepage, só que possui outros recursos disponíveis. Essa página, mostrada na figura 18, é um tipo de página conhecida no WebCT como Tool Page. Ela pode ser totalmente configurada pelo desenvolvedor, que pode inserir nela qualquer recurso que achar interessante para seu curso.

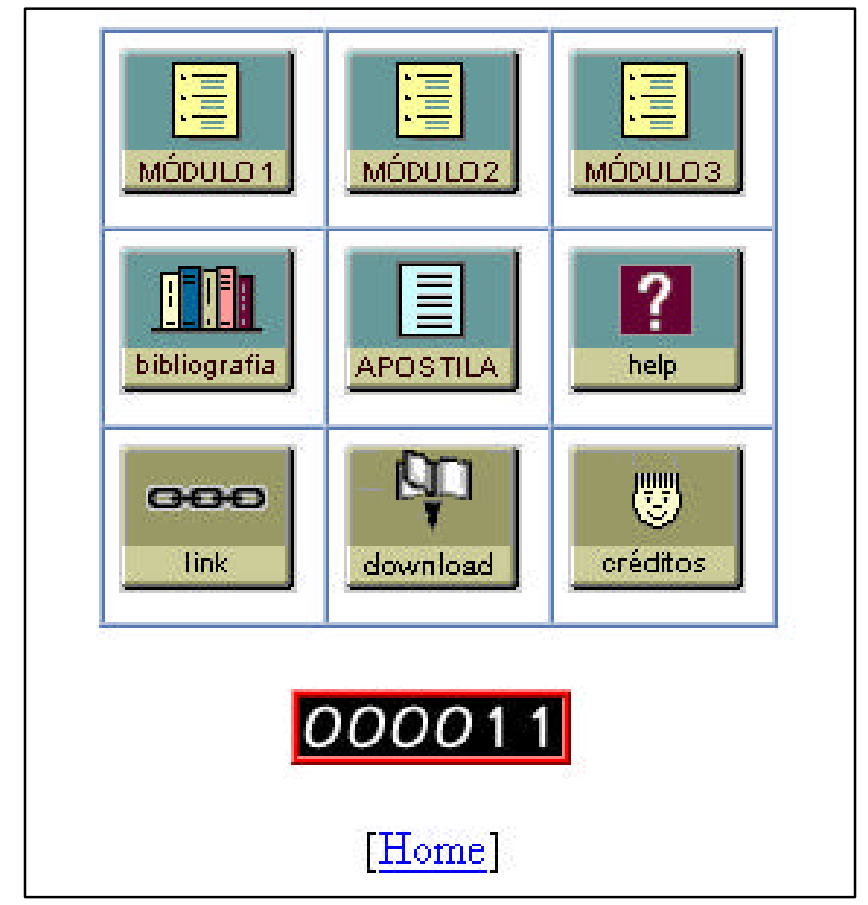

FIGURA 18 - Página do curso que é aberta pelo ícone "contents" 
Por terem uma grande importância no curso, os ícones "módulo 1", "módulo 2" e "módulo 3", mostrados na figura 18, merecem uma descrição mais detalhada. A partir dessa descrição, a relação entre o PCP e o ambiente de aprendizagem desenvolvido, que parece inexistente até o momento, ficará clara.

\section{OS TRÊS MÓDULOS}

Conforme já foi comentado, além das ferramentas e recursos próprios do WebCT, o desenvolvedor também pode inserir em seu curso quaisquer materiais externos que julgar conveniente (arquivos multimídia, planilhas, artigos que estão no formato do Microsoft Word, apresentações do Microsoft PowerPoint, etc).

No caso do curso desenvolvido neste trabalho, foi criado um conjunto de páginas HTML com recursos hipermídia, tendo como conteúdo aqueles assuntos de PCP escolhidos anteriormente. Apesar do WebCT possuir um editor de páginas HTML próprio, essas páginas foram criadas externamente ao WebCT, através de outros softwares. Depois de prontas, elas foram descarregadas no servidor do WebCT (portanto, foi feito um upload: enquanto download significa enviar arquivos do servidor para um computador local, upload significa enviar arquivos de um computador local para o servidor; um recurso do WebCT chamado File Manager, disponível ao desenvolvedor, facilita muito as interações computador local/servidor WebCT).

Os assuntos escolhidos, por representarem três temas distintos (ainda que relacionados), foram divididos em três módulos separados:

\section{Módulo 1 - "Planejamento e Controle da Produção" \\ Módulo 2 - "Previsão de Vendas" \\ Módulo 3 - "Planejamento e Controle de Estoques"}

Os módulos são acessados, respectivamente, através dos ícones "módulo 1", "módulo 2" e "módulo 3", mostrados na figura 18. Neste trabalho, a palavra módulo é usada apenas para reforçar a idéia de separação física existente entre os três temas, já que no curso eles são acessados através de três ícones diferentes. Ela não tem qualquer outra conotação especial.

Cada um dos módulos possui uma página principal. Essa página principal 
possui uma lista com todos os tópicos que fazem parte de um módulo. Aqui, tópico é entendido como sendo uma ou mais páginas HTML que tratam de um mesmo assunto dentro do módulo. Como exemplo, dentro do Módulo 3 - "Planejamento e Controle de Estoques", existe o tópico 3.3 - "Tipos de Estoque". Os tópicos seguem a numeração dos módulos (no Módulo 3, por exemplo, os tópicos são numerados como 3.1, 3.2, 3.3 e assim por diante). A tabela 4 mostra os tópicos dos módulos.

TABELA 4 - Os tópicos dos três módulos

\begin{tabular}{|c|c|}
\hline \multicolumn{2}{|r|}{ Módulo 1 - "Planejamento e Controle da Produção" } \\
\hline $\begin{array}{l}1.1 \\
1.2 \\
1.3 \\
1.4 \\
1.5 \\
1.6 \\
1.7 \\
1.8 \\
1.9 \\
1.10\end{array}$ & $\begin{array}{l}\text { Empresas e Produtos } \\
\text { Sistemas de Produção } \\
\text { Tipos de Sistemas de Produção } \\
\text { Administração da Produção } \\
\text { Atividades da Administração da Produção } \\
\text { Modelo de Administração da Produção } \\
\text { Definição de Planejamento e Controle da Produção (PCP) } \\
\text { Atividades do PCP } \\
\text { O PCP e o Tipo de Sistema de Produção } \\
\text { Relações do PCP com Outras Áreas da Empresa }\end{array}$ \\
\hline \multicolumn{2}{|r|}{ Módulo 2 - "Previsão de Vendas" } \\
\hline $\begin{array}{l}2.1 \\
2.2 \\
2.3 \\
\\
2.4 \\
2.5 \\
\end{array}$ & $\begin{array}{l}\text { Previsão nas Empresas } \\
\text { Previsões e Predições } \\
\text { Métodos de Previsão e Predição } \\
\text { 2.3.1 Métodos Qualitativos } \\
\text { 2.3.2 Métodos Quantitativos } \\
\text { Erros de Previsão } \\
\text { Qual Método Escolher }\end{array}$ \\
\hline & Módulo 3 - "Planejamento e Controle de Estoques" \\
\hline $\begin{array}{l}3.1 \\
3.2 \\
3.3 \\
3.4 \\
3.5 \\
3.6\end{array}$ & $\begin{array}{l}\text { O Que é Estoque } \\
\text { Importância do Estoque } \\
\text { Tipos de Estoque } \\
\text { Custos de Estoque } \\
\text { O Gráfico Dente de Serra } \\
\text { Decisões de Estoque } \\
\text { 3.6.1 Quanto Pedir } \\
\text { 3.6.2 Quando Pedir } \\
\text { 3.6.3 Como Controlar o Estoque }\end{array}$ \\
\hline
\end{tabular}

Ao clicar sobre os ícones "módulo 1", "módulo 2" e "módulo 3", o usuário é levado automaticamente para a página principal do módulo correspondente. Como exemplo, a figura 19 mostra a página principal do Módulo 3. 


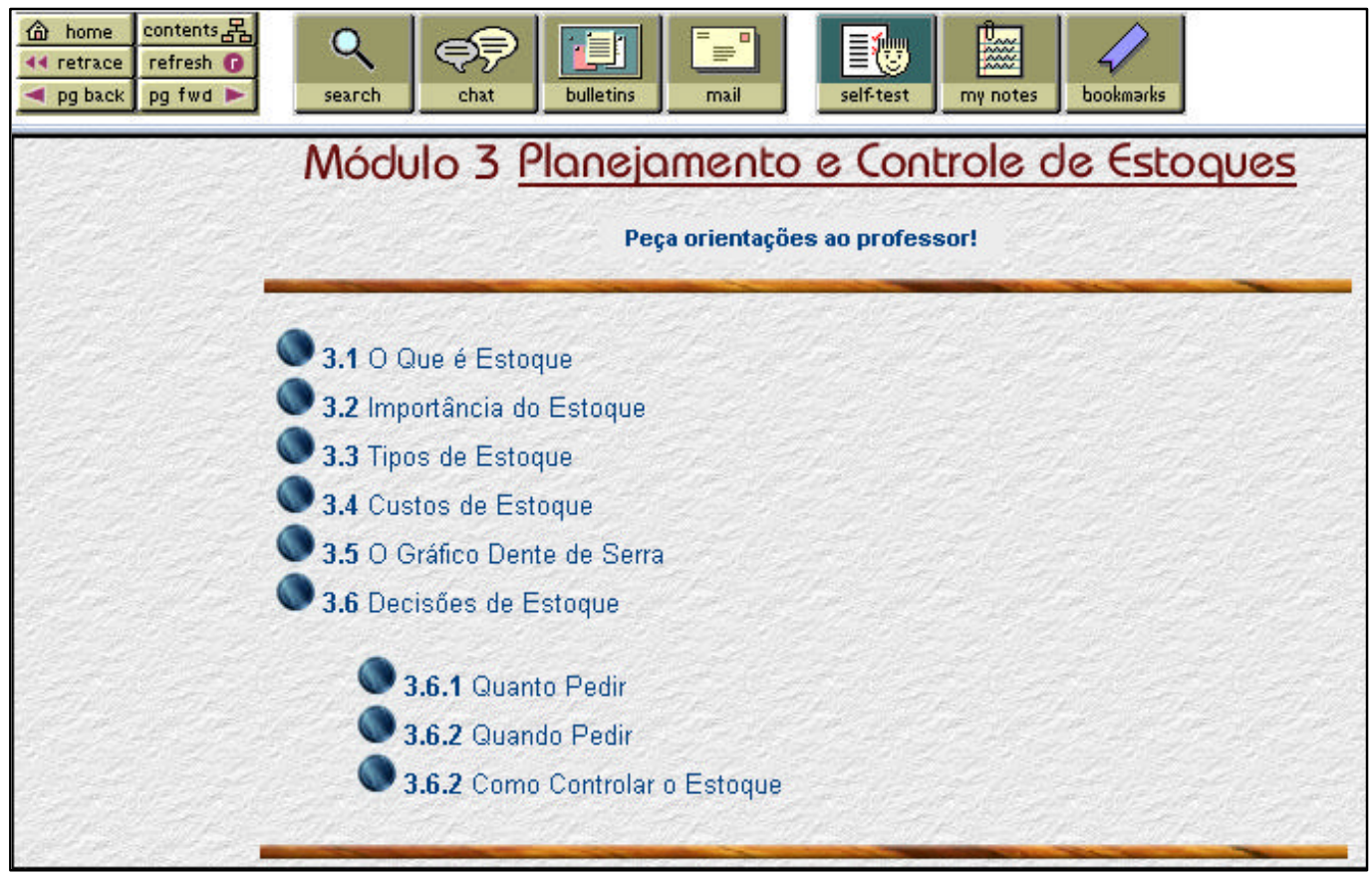

FIGURA 19 - Página principal do Módulo 3

Sempre que estiver navegando em um módulo, o usuário terá a tela do seu computador dividida em duas partes (veja a figura 19): na parte de baixo estará a página principal (ou algum tópico que ele vier a escolher para navegar) e a de cima mostrará uma barra de navegação e algumas ferramentas do WebCT. Enquanto estiver navegando pelos tópicos, o usuário poderá utilizar qualquer uma dessas ferramentas. Definir quais ferramentas estarão disponíveis ao usuário, em qualquer local do curso, é sempre uma decisão do desenvolvedor.

\section{PATH}

A figura 20 mostra a barra de navegação que sempre aparece quando um usuário navega por um módulo.

\begin{tabular}{|l|l|}
\hline 合 home & contents 吕 \\
\hline 44 retrace & refresh C \\
\hline 4 pg back & pg fwd \\
\hline
\end{tabular}

FIGURA 20 - Barra de navegação 
Para navegação, devem ser utilizados os botões "pg back" (ir para o tópico anterior) e "pg fwd" (ir para o próximo tópico). Isso porque todos os tópicos de um módulo foram organizados em um path, ou seja, em um caminho pré-determinado. O path já foi discutido anteriormente, nos itens 3.2.2 e 4.1.2. Aqui, seu objetivo é evitar que o usuário se perca na rede de páginas que formam o módulo, permitindo também que ele navegue por um caminho onde os assuntos são apresentados na ordem mais apropriada. Sem o path, além do risco de desorientação, o usuário poderia escolher os assuntos em uma ordem que talvez não seria a mais correta (por exemplo, ele poderia ir para o tópico "Métodos de Previsão e Predição" antes de visitar o tópico que explica o que é previsão ou predição). O path é um recurso do WebCT que está disponível ao desenvolvedor do curso.

Conforme já esclarecido, cada tópico é formado por uma ou mais páginas. Utilizando os botões "pg back" e "pg fwd", o usuário será levado sempre para a página inicial do tópico. Como exemplo, a figura 21 mostra a página inicial de dois tópicos consecutivos do Módulo 1. Estando no tópico 1.2 - "Sistemas de Produção", o usuário irá para a página inicial do tópico 1.3 - "Tipos de Sistemas de Produção" ao clicar no botão "pg fwd". De outra forma, estando no tópico 1.3 - "Tipos de Sistemas de Produção", o usuário irá para a página inicial do tópico 1.2 - "Sistemas de Produção" ao clicar no botão "pg back".

No caso do tópico possuir mais de uma página, haverá, na página inicial, um link para as outras páginas que formam o tópico. Clicando nesse link, uma nova janela será aberta com a página requisitada (a página inicial continuará aberta na outra janela, permitindo que o usuário saiba sempre em qual tópico está). Algumas páginas que serão abertas nessa nova janela terão botões de navegação próprios, localizados no final da página. A figura 22 mostra esses botões (eles servem para navegar através do tópico; para navegar entre os tópicos, ou seja, de um tópico a outro, devem ser utilizados os botões "pg back" e "pg fwd").

Apesar do path criar um caminho pré-determinado, o usuário pode "fugir" dele sempre que achar necessário. Isso é possível através do botão "contents", da barra de navegação (o ícone mostrado nas figuras 14 e 17 não possui qualquer relação com esse botão, apesar da coincidência dos nomes). Clicando nele, o usuário é levado até uma página onde há links para todos os tópicos do módulo. Ele pode, então, escolher qual deseja visitar. 


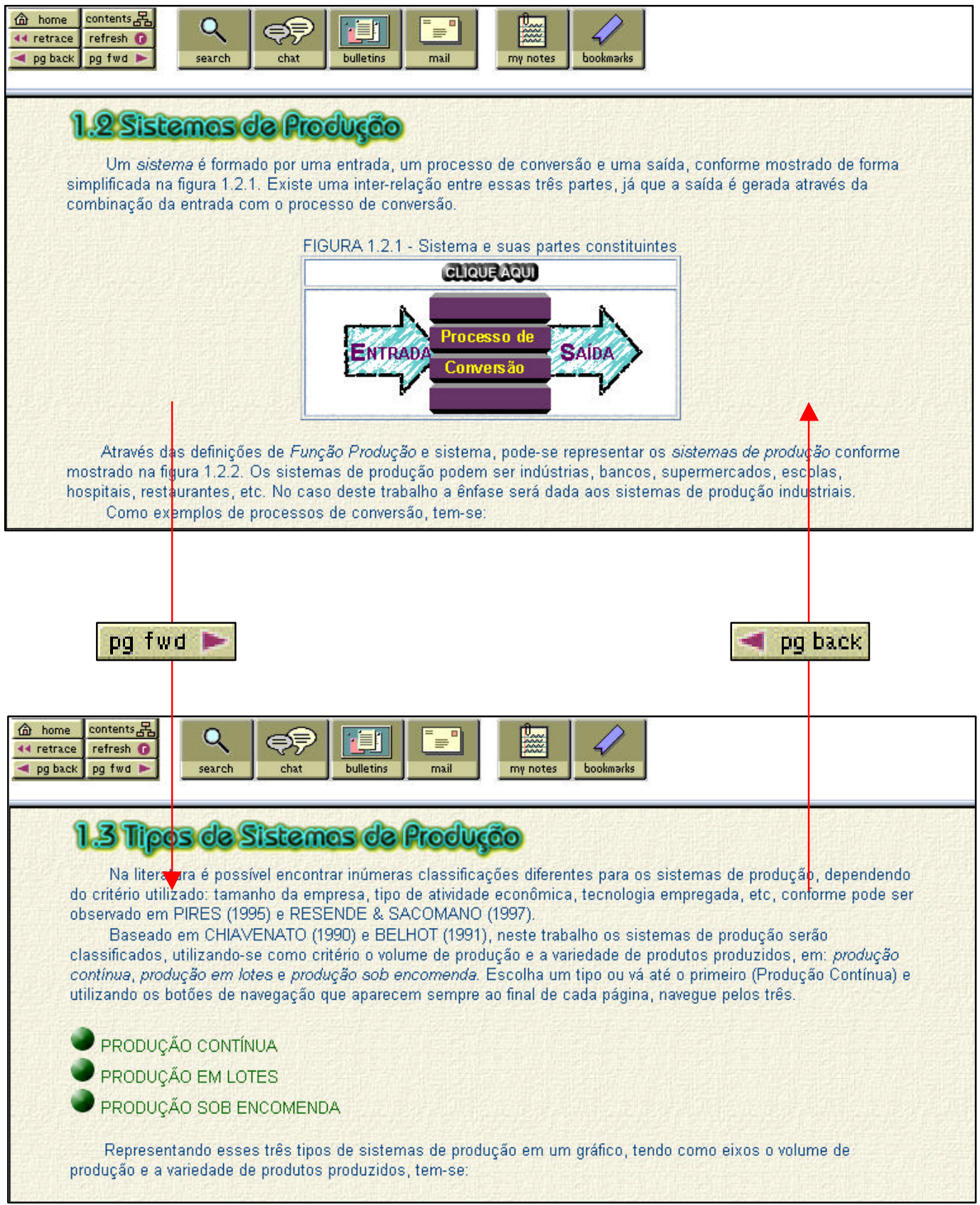

FIGURA 21 - Exemplo de navegação através dos botões "pg fwd" e "pg back"

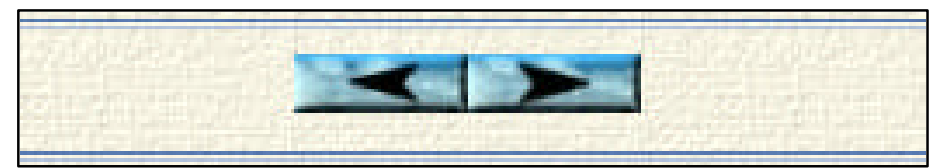

FIGURA 22 - Botões de navegação presentes em algumas páginas 
Outro modo de evitar o path é clicar no link "página principal módulo", que aparece sempre no final da página inicial de cada tópico. Clicando nesse link, o usuário é levado até a página principal do módulo, que lista todos os tópicos e possui links para a página inicial de todos eles.

Na figura 23 estão esquematizados os modos de navegação em um módulo (o botão "contents" da barra de navegação não está representado).

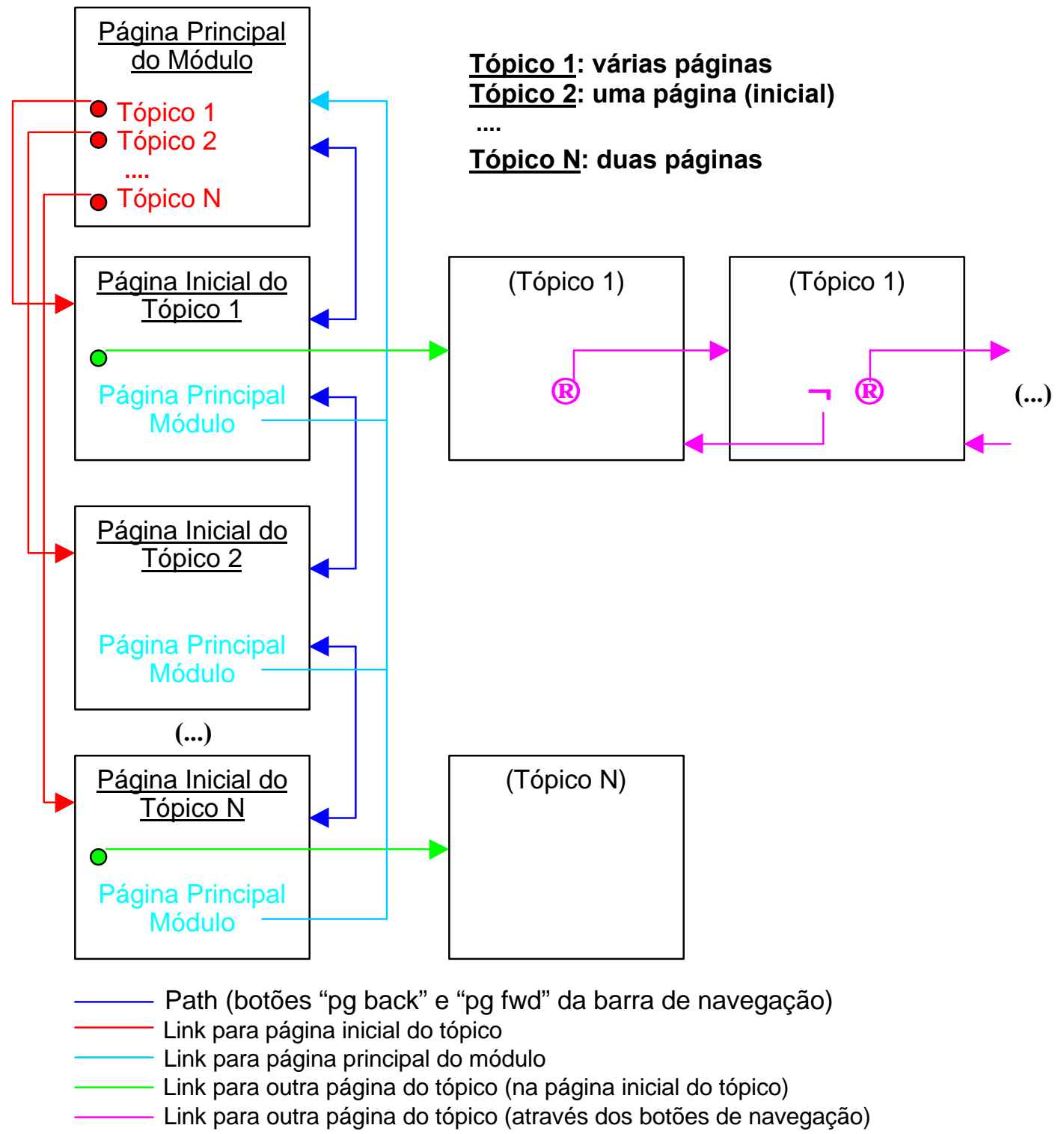

FIGURA 23 - Modos de navegação em um módulo 


\section{OUTROS BOTÕES DA BARRA DE NAVEGAÇÃO}

A barra de navegação possui outros botões, além daqueles já citados ("pg back", "pg fwd" e "contents"). São eles:

- "Home": link para a Homepage;

- "Retrace": volta para o tópico anterior. Enquanto o botão "retrace" volta para o último tópico visitado, o botão "pg back" volta para o tópico imediatamente anterior ao atual dentro do path;

- "Refresh": recarrega a página inicial do tópico atual.

\section{RECURSOS DAS PÁGINAS DOS MÓDULOS}

As páginas que formam os módulos possuem recursos hipermídia para facilitar o entendimento do assunto, tais como: figuras, gráficos, animações, etc. Navegando pelos módulos o usuário poderá desfrutar de todos os recursos.

Para facilitar a localização dentro do módulo, todas as páginas possuem um mapa que indica em qual módulo e qual tópico o usuário está (localizado no final da página). A figura 24, que mostra o mapa de uma página, indica que o usuário está visitando o tópico "O Gráfico Dente de Serra", do Módulo 3.

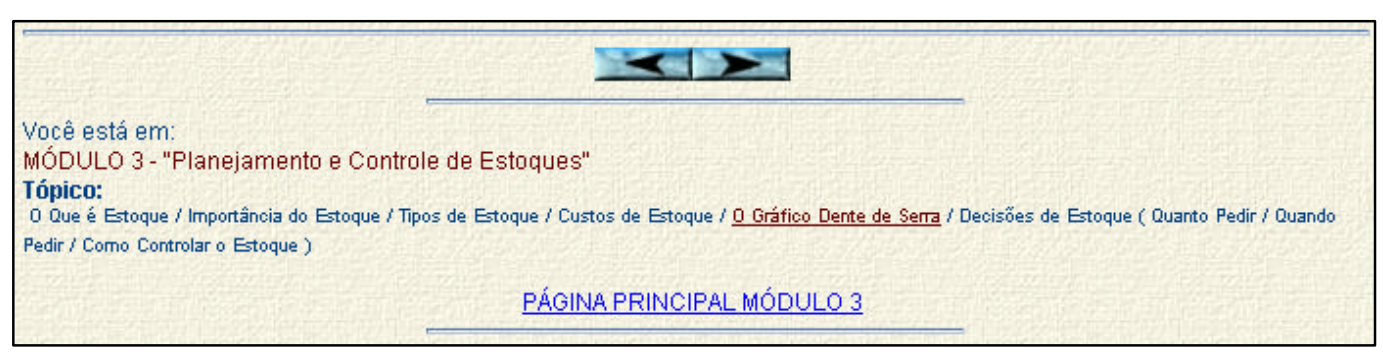

\section{FIGURA 24 - Mapa de uma página}

Algumas páginas que apresentam assuntos que envolvem cálculos (por exemplo, as páginas do tópico que trata dos métodos de previsão, no Módulo 2), permitem que o usuário faça download de planilhas do Microsoft Excel para treinar os conhecimentos adquiridos. Através dessas planilhas, o usuário pode resolver exercícios fornecendo seus próprios dados, além de analisar os resultados em gráficos. A figura 25 mostra uma dessas planilhas. 


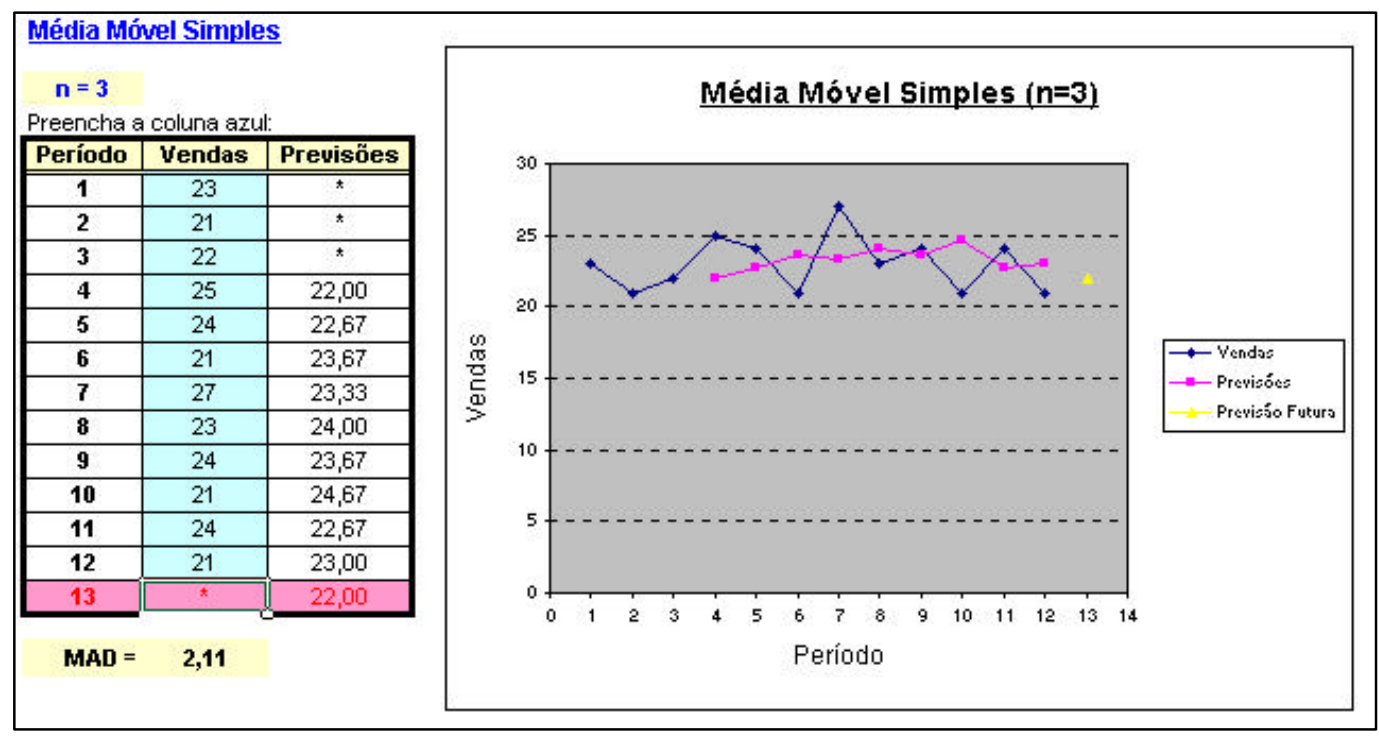

FIGURA 25 - Uma das planilhas que o usuário pode fazer download

Na página principal dos três módulos, na parte de cima da tela (onde estão a barra de navegação e as ferramentas do WebCT), existe o ícone "self test". Clicando nele, o usuário será levado a um teste com questões de múltipla escolha envolvendo todos os assuntos tratados no módulo.

\section{OUTROS ÍCONES}

Além dos ícones que levam até os módulos ("módulo 1", "módulo 2" e "módulo 3"), a página do curso mostrada anteriormente na figura 18 também possui outros ícones. São eles:

- "Bibliografia": é um link para uma página que mostra a bibliografia usada no desenvolvimento dos três módulos;

- "Apostila": é um link para a versão on-line da apostila da disciplina. É como se fosse um outro módulo do curso. Ao clicar nesse ícone, o usuário é levado até a página principal da apostila. Pode, então, escolher um tópico para navegar. Da mesma forma que nos módulos, a tela fica dividida em duas (na parte de baixo ficam as páginas da apostila e em cima a barra de navegação e as ferramentas do WebCT). Portanto, a apostila também está organizada em um path; 
- "Help": link para uma página de ajuda, que explica a função de cada um dos ícones da figura 18;

- "Link": leva a uma página com links para sites da Web com assuntos interessantes relacionados com a disciplina;

- "Download": leva a uma página onde o usuário pode fazer download de materiais da disciplina, como exercícios, tarefas, propostas de trabalhos, etc;

- "Créditos": link para a página de créditos do curso.

\section{CONTEÚDO DE UM CURSO DO WEBCT}

Por ser bastante simples de usar, o WebCT permite que o desenvolvedor modifique o conteúdo de seu curso de acordo com a sua vontade, quando achar necessário. Assim, ele pode inserir novas ferramentas, retirar aquelas que os alunos não estiverem usando, disponibilizar novos recursos, descarregar arquivos no servidor do WebCT para que os alunos possam acessá-los via rede, pedir a opinião dos alunos sobre o conteúdo geral do curso (através de uma survey, por exemplo) e incluir no curso materiais criados externamente ao WebCT.

A principal diferença entre um curso e outro do WebCT está justamente nos materiais externos que são incluídos, como figuras, fotos, arquivos de áudio, vídeo, páginas HTML (como os três módulos desenvolvidos neste trabalho), etc. Isso porque as formas dos cursos são bem semelhantes entre si, já que em todos existem a Homepage, as ferramentas (apesar do desenvolvedor ter a liberdade de escolher quais estarão disponíveis), contas individuais de acesso, a My WebCT, etc.

A preparação do material externo é a etapa do desenvolvimento que pode exigir mais planejamento, tempo, trabalho e cuidado. Evidentemente, isso vai depender da qualidade do material e do seu objetivo.

\section{SOFTWARES UTILIZADOS}

$\mathrm{Na}$ criação dos três módulos, da versão on-line da apostila e de outros materiais externos inseridos no curso descrito, foram utilizados vários softwares. Todos eles pertencem ao Laboratório de Multimídia e Processamento Científico (LMPC), da Área de Engenharia de Produção da Escola de Engenharia de São 
Carlos, onde o curso foi desenvolvido.

Os softwares utilizados representam alguns dos líderes de mercado em suas respectivas categorias. De modo geral, todos são simples de usar, apesar de possuírem recursos sofisticados. No entanto, a simplicidade de uso costuma ser uma questão relativa, já que a criatividade do usuário conta muito. Além disso, se o usuário deseja algo muito complexo, seus conhecimentos sobre o software e seus recursos deverão ser proporcionais a essa complexidade.

No mercado existe um grande leque de opções de softwares que trabalham com arquivos aceitos pela Web (o ambiente do WebCT). Algumas das principais diferenças estão relacionadas ao preço, aos recursos disponíveis e a facilidade de uso.

A seguir estão brevemente descritos os principais softwares utilizados:

\section{Corel DRAW e Corel PHOTO-PAINT (ambos da Corel Corporation)}

São softwares para criação de imagens eletrônicas.

Os softwares que criam imagens eletrônicas são baseados em elementos gráficos vetoriais ou em imagens em formato bitmap. O Corel DRAW trabalha com elementos gráficos baseados em vetores e o Corel PHOTO-PAINT com imagens em formato bitmap.

De forma simples, as imagens vetoriais são definidas matematicamente como uma série de pontos unidos por linhas. Em um arquivo vetorial, os elementos gráficos são chamados de objetos. Cada objeto é uma entidade independente com características próprias, como cor, forma, tamanho, posição na tela, etc.

Já as imagens bitmap são formadas por pontos individuais chamados de pixels, que podem ser dispostos e coloridos de maneiras diferentes para formar um padrão. Nas imagens bitmap, é possível aperfeiçoar pequenos detalhes, fazer grandes alterações e intensificar efeitos. No entanto, como uma imagem bitmap é formada por um conjunto de pixels organizados, suas partes não podem ser manipuladas individualmente.

\section{Fireworks (Macromedia)}

Software para criação de imagens eletrônicas desenvolvido especialmente para a Web. Simples de usar e com vários recursos e efeitos disponíveis. Permite a criação de arquivos com tamanho final reduzido e com ótima qualidade. Ele mistura os conceitos de imagem vetorial e bitmap. 


\section{Flash (Macromedia)}

Permite criar animação e interatividade sofisticadas para a Internet (Web). Arquivos de áudio, figuras e fotos podem ser incluídos nas animações. Os arquivos finais podem ser salvos em diversos formatos, como o shockwave flash e o avi.

O Flash vem ganhando muita popularidade na Web. Seus recursos dão uma aparência profissional às páginas. Pequenas e grandes empresas do Brasil e do exterior estão desenvolvendo ou já desenvolveram seus sites através dele. Existem várias comunidades de usuários do Flash em todo o mundo, inclusive aqui no Brasil.

\section{Composer (Netscape) e Dreamweaver (Macromedia)}

São editores de páginas HTML. O primeiro é muito simples de usar, não dispõe de muitos recursos e vem no pacote do Communicator (um conjunto de softwares que inclui ainda o navegador Netscape Navigator). O segundo já é bem mais sofisticado, inclui recursos para tornar um objeto interativo sem exigir do usuário conhecimento sobre a linguagem JavaScript (muito usada na Web), entre vários outros recursos. 


\section{Capítulo 6 - Conclusão}

De acordo com VALENTE (1993), o que transparece é que a introdução dos computadores na educação tem criado mais controvérsias e confusões do que indicado soluções para os problemas da educação. Por exemplo, o computador provocou questionamentos dos métodos e da prática educacional. Também provocou insegurança em alguns professores que acham, entre outras coisas, que serão substituídos pela máquina. Além disso, existe o custo financeiro para implantar e manter os computadores.

Durante cada revolução tecnológica, sempre houve quem temesse os impactos das mudanças e quem pregasse que ela transformaria tudo. Assim, toda a perturbação que a presença do computador vem causando é absolutamente natural e, de certo modo, até sadia. A inserção de uma inovação tecnológica em qualquer organização exige discussões cuidadosas em torno de seus pontos fortes e fracos (sempre existentes), do seu impacto na cultura existente e das suas reais possibilidades na promoção das mudanças desejadas. Portanto, considerando que a presença do computador é inevitável, a discussão em torno da sua utilização é muito bem-vinda. No caso da educação, torna-se obrigatória.

No entanto, o fato é que o computador não pode ser analisado no contexto educacional como um outro recurso qualquer, como o giz, o quadro-negro ou o retro-projetor. Sua presença transforma profundamente o ambiente, causando admiração e medo nos mais inexperientes. Ele também modifica os papéis de alunos e professores, o que pode causar desconforto e insegurança. Sua utilização não é automática. Não basta sentar na sua frente e apertar um botão, é preciso treinamento, contato direto e domínio de tecnologias que surgem a cada dia. Além disso, seu custo ainda é relativamente elevado.

Por outro lado, a utilização do computador também não pode ser analisada 
como um processo movido pela inércia de que tudo deve se modernizar. O que se busca não é a modernização, mas sim o enriquecimento do processo de ensinoaprendizagem através dos benefícios trazidos pelos novos recursos tecnológicos. Ter computadores nas escolas não basta, é preciso que eles sejam utilizados para a mudança das relações e dos meios de ensino-aprendizagem. Para VALENTE (1993, p.41), "o objetivo da introdução do computador na educação não deve ser o modismo ou estar atualizado com relação às inovações tecnológicas. Esse tipo de argumentação tem levado a uma sub-utilização do computador que, além de economicamente dispendiosa, traz poucos benefícios para o desenvolvimento intelectual do aluno".

Portanto, é necessário orientar (ou reorientar) a discussão em torno do computador na direção do verdadeiro objetivo pretendido: a melhoria do processo de ensino-aprendizagem. Partindo desse ângulo, as análises e discussões deverão proporcionar esclarecimentos, idéias e experiências que irão favorecer a troca de uma visão conservadora e com fronteiras limitadas, que enxerga na tecnologia um recurso de automação da educação, tornando-a um sistema educacional-industrial, para uma visão norteada nas mudanças de paradigma, com o foco na questão pedagógica.

O uso do computador na educação é sustentado por outras tecnologias, como as tecnologias da informação e da comunicação. Assim, é preciso estender a discussão a um conceito de tecnologia mais geral do que aquele que considera o computador isoladamente. Além disso, qualquer tecnologia utilizada na educação sempre será um meio para se atingir um fim, nunca um fim em si, porque o fim está na pessoa: seja no aluno (aprendizagem), seja no professor (ensino). Portanto, há a necessidade também de estender a discussão a um contexto mais amplo do que o da tecnologia, considerando pontos críticos relacionados ao professor e ao aluno, como suas dificuldades e os novos papéis que deverão desempenhar.

As novas tecnologias devem ser repensadas como elementos catalisadores e facilitadores do desenvolvimento de novas estratégias, práticas e métodos de ensino que favoreçam a construção do conhecimento pelo aluno. O computador, principal elemento tecnológico viabilizador das mudanças na educação, junto com a Internet, a multimídia, a hipermídia e tantos outros recursos disponíveis, devem ser encarados como instrumentos que poderão contribuir com novas formas de aprendizagem, com novas modalidades de laços sociais e como meios alternativos de acesso ao conhecimento. 
Não se pode desprezar o potencial educacional dos novos recursos tecnológicos simplesmente por existirem exigências e limitações relacionadas ao seu emprego. Condições de contorno existem em qualquer situação. As grandes mudanças exigem sacrifícios e uma longa fase de adaptação para que os melhores resultados sejam alcançados. Assim, é preciso desenvolver mais pesquisas sobre o assunto e promover trocas de experiências, de modo a conhecer problemas, dificuldades, vantagens e desvantagens envolvidas com a utilização das novas tecnologias na educação.

Deve ser ultrapassado o nível de discussão que enxerga no computador um substituto do professor. Cada um, professor e computador, desempenham suas funções melhor do que o outro e representam peças fundamentais no processo educacional. Em vez de substituir, o computador oferece ao professor novas oportunidades de atualização, novos métodos de ensino, pesquisa e comunicação. A constatação da necessidade de domínio da máquina em benefício próprio talvez seja a origem do medo e repulsa de alguns professores, principalmente os mais tradicionais. Se, por acaso, algum professor vier a perder seu lugar por causa de um computador, é muito provável que esse professor merecesse ser substituído, se não por uma máquina, pelo menos por outro professor.

Com relação aos métodos e práticas atualmente empregados na educação em engenharia, o computador também não veio substituí-los, mas complementálos, ampliando as possibilidades educacionais em benefício de todos: professores, alunos, sistema educacional, sociedade, nação. Como defende PALADINI (1996, p.147), "o ensino de engenharia neste final de século, espera-se, deve acompanhar o ritmo do desenvolvimento tecnológico que caracteriza a evolução da engenharia como um todo. Neste sentido, não cabem mais, hoje, posturas que visam manter padrões ultrapassados de ensino, mostrando suas vantagens pelo fato de serem característicos do modelo ensino-aprendizagem da engenharia. Neste sentido, duas posições são prejudiciais: ignorar métodos usuais de ensino pelo simples fato de serem antigos ou, por outro lado, ater-se aos processos tradicionais, sem considerar a possibilidade de tirar partido de mecanismos avançados de software ou hardware".

Por fim, deve estar claro que o computador ou qualquer outra tecnologia não é uma panacéia para todos os males da educação brasileira. Dependendo da maneira como for utilizado, o computador tanto pode educar, quanto deseducar, ampliando problemas já existentes e, o que é mais grave, criando novos. Melhorar 
o processo de ensino-aprendizagem não é um atributo inerente ao computador, mas uma consequência que está vinculada ao modo como é concebido o papel que ele deverá desempenhar. Uma tecnologia só pode ser classificada como boa ou ruim se forem analisados o contexto e a maneira como ela foi empregada.

\section{1 - CONTRIBUICCÃO DESTE TRABALHO}

Este trabalho procurou mostrar como o computador, auxiliado pelas novas tecnologias da informação e da comunicação, pode contribuir para melhorar o processo de ensino-aprendizagem na educação em engenharia.

Evidentemente, o trabalho não teve a pretensão de esgotar todo o assunto relacionado ao tema. Porém, partindo de uma determinada perspectiva, ainda que pessoal, é possível acreditar que qualquer tentativa de contribuir com a pesquisa em torno da melhoria da educação torna-se válida, principalmente em um país como o Brasil, onde a injustiça e as desigualdades sociais ultrapassam o nível do absurdo e, portanto, a educação pode ter um papel ainda muito mais amplo.

A soma de trabalhos já existentes com aqueles que deverão surgir, ainda que cada um contribua apenas com um pequeno passo, certamente permitirá chegar a um ponto onde a discussão será formada mais por respostas otimistas do que por dúvidas pessimistas, tornando possível a transformação definitiva do computador e de outros recursos em instrumentos parceiros do professor e do aluno em suas respectivas funções: ensinar e aprender.

Quanto ao ambiente de aprendizagem descrito no capítulo anterior, cujo desenvolvimento serviu para que algumas questões, experiências e conceitos discutidos neste trabalho fossem colocados em prática, existe a esperança que ele também sirva como exemplo para outros projetos semelhantes, não apenas na Área de Engenharia de Produção, mas em outros departamentos da EESC-USP ou em outras escolas.

Entre outras coisas, o ambiente desenvolvido apresenta:

- independência de softwares ou hardwares de última geração;

- sistemas de navegação lineares e não lineares;

- botões e links que facilitam a movimentação;

- mapas/paths que reduzem a possibilidade de desorientação e sobrecarga cognitiva;

- páginas de ajuda; 
- interface simples, interativa, intuitiva e com um bom balanço visual entre os elementos dispostos na tela;

- recursos hipertexto que melhoram o acesso à informação;

- recursos multimídia que melhoram a apresentação da informação;

- ferramentas onde os alunos podem colocar suas anotações, comentários, dúvidas, etc;

- interface para serviços de busca da Web;

- sistemas de auto-avaliação, testes, etc;

- área para armazenamento e distribuição de materiais da disciplina;

- recursos que facilitam o gerenciamento do ambiente e das contas dos alunos;

- ferramentas que facilitam o suporte ao aluno.

Durante o desenvolvimento de um software educativo, deve haver um cuidado especial para que não haja a criação de um livro eletrônico, onde o aluno apenas participa na hora de mudar de página. As planilhas do Microsoft Excel, que estão disponíveis para download em várias páginas dos três módulos, além de várias ferramentas do WebCT, como o chat, mail, dropbox, whiteboard e bulletins, são alguns dos recursos incluídos no ambiente para incentivar uma atitude mais ativa do aluno durante seu processo de aprendizagem. Espera-se que esses recursos também possam contribuir para melhorar a motivação, a comunicação e a cooperação entre os alunos da disciplina SEM-387 "Planejamento e Controle da Produção l”.

Infelizmente, não foi possível aplicar no ambiente de aprendizagem tudo o que foi discutido neste trabalho. A falta de uma equipe multidisciplinar no Laboratório de Multimídia e Processamento Científico sobrecarregou várias etapas do desenvolvimento e não permitiu o aprofundamento desejado em outras, o que, pelo menos, serviu para comprovar a importância da participação de pessoas com conhecimentos em diferentes áreas na criação de um software educativo. Além disso, questões relacionadas ao professor e ao aluno, como as discutidas no Capítulo 4, extrapolam as atividades envolvidas apenas com o processo de desenvolvimento de um software educativo e, quando o objetivo é a melhoria do processo de ensino-aprendizagem, estão mais fortemente ligadas à preparação desses personagens para o uso das novas tecnologias no contexto educacional.

Alguns problemas relacionados com o desenvolvimento do ambiente, como 
a lentidão da rede Internet e a limitação natural da linguagem HTML (que acaba exigindo a utilização de outras linguagens), merecem ser comentados, porém são relativamente contornáveis.

Também deve ser levado em conta o período de tempo que é gasto para aprender a usar todos os softwares, o que, diga-se de passagem, é um problema que não merece muita preocupação, já que há uma tendência entre os fabricantes no sentido de tornar os softwares cada vez mais simples de usar, ao mesmo tempo em que agregam recursos mais complexos. Há exceções, é claro, principalmente quando é preciso trabalhar com alguma linguagem de programação, situação em que o tempo de aprendizagem pode ser bem maior. De modo geral, porém, discutir tempo de aprendizagem é uma questão bastante relativa, já que depende da experiência das pessoas que estão envolvidas no projeto.

Um outro problema refere-se à falta de metodologias de desenvolvimento específicas para softwares educativos. Em comunhão com outras áreas como a Pedagogia e a Psicologia, a Engenharia de Software poderia explorar mais essa questão.

Com relação ao WebCT, conforme já foi discutido, a maior dificuldade no desenvolvimento de um curso é a preparação do material externo que será incluído nele. Criar as páginas HTML, incluir figuras, animações e mídias, preparar o texto e definir os links são algumas das tarefas envolvidas que merecem um bom planejamento e conhecimento a respeito de softwares, interface e sobre o próprio assunto da disciplina que o curso irá apoiar.

O professor que pretende criar um curso no WebCT apenas com algumas ferramentas e incluir poucas páginas com informações gerais sobre a disciplina, terá muito menos trabalho do que aquele que busca criar realmente um ambiente de aprendizagem para seus alunos. Assim, no segundo caso, o material externo a ser incluído deverá ser muito bem preparado, como forma de assegurar um mínimo de qualidade. O mais importante é que o material corresponda aos objetivos pretendidos com a criação do curso.

Antes de ser aplicado definitivamente na disciplina, servindo como recurso instrucional de apoio às aulas, o ambiente de aprendizagem desenvolvido deverá passar pelas etapas de verificação e validação, que não foram realizadas principalmente devido ao tempo relativamente limitado envolvido em um programa de mestrado e pelo fato da disciplina ser ministrada apenas uma vez ao ano, durante um semestre. Pela importância dessas duas etapas, optou-se por realizá- 
las mais tarde, com os cuidados e o rigor necessários, que poderiam ficar comprometidos neste trabalho.

Pensando a longo prazo, espera-se que o ambiente de aprendizagem possa servir, de alguma forma, como uma semente de algum projeto de educação a distância na Área de Engenharia de Produção da EESC-USP. Considerando o seu grande crescimento, as diferentes modalidades disponíveis e sua importância para o Brasil, a educação a distância deve começar a fazer parte das discussões de todos os envolvidos com educação, inclusive aqueles envolvidos apenas com a educação presencial tradicional. Trata-se de uma questão estratégica para o país.

Por fim, retomando o Ciclo de Aprendizagem descrito no item 2.4, é interessante notar que os recursos computacionais hoje disponíveis permitem criar produtos que facilitam a movimentação pelas quatro fases do Ciclo. Um software educativo tal qual o que foi desenvolvido neste trabalho pode auxiliar o professor a:

- criar nos alunos a motivação para aprender o assunto a ser ensinado (através, por exemplo, dos recursos hipermídia);

- fornecer aos alunos os conceitos relacionados ao assunto (através, por exemplo, das páginas HTML organizadas através de paths);

- incentivar os alunos a desenvolverem técnicas e modelos para a solução de problemas;

- fornecer oportunidades para a auto-descoberta (esses dois últimos casos através, por exemplo, das situações que poderiam ser criadas através das ferramentas que facilitam a comunicação e a cooperação).

Isso é possível, evidentemente, partindo-se da hipótese de que o professor e o aluno tenham sido preparados para exercerem seus novos papéis diante das novas tecnologias: um sendo o facilitador da aprendizagem e o outro o seu parceiro ativo, participativo e cooperativo. A preparação desses dois elementos, aliás, foi uma das questões que este trabalho procurou discutir e, considerando sua enorme importância no binômio tecnologia-educação, exaltar.

\section{2 - PROPOSTA PARA TRABALHOS FUTUROS}

Algumas propostas de trabalhos que poderiam ser desenvolvidos, como continuidade deste: 
- trabalhos que proponham novos métodos ou práticas de ensino que empreguem o computador e respondam a requisitos do novo paradigma da educação em engenharia;

- pesquisas relacionadas com o uso da Internet na educação;

- pesquisas que analisem a importância, dificuldades e possibilidades do uso do computador/Internet na educação a distância;

- trabalhos que descrevam novos recursos tecnológicos que podem ser ou já estão sendo utilizados na educação;

- trabalhos que discutam a importância da preparação dos professores para o uso das novas tecnologias;

- pesquisas que busquem definir critérios de avaliação da aprendizagem, quando ela é realizada com a ajuda de recursos tecnológicos;

- experiências com a utilização do Ciclo de Aprendizagem.

Também poderia ser incentivada a criação de uma equipe multidisciplinar integrando profissionais de diferentes cursos, áreas e departamentos para o desenvolvimento de softwares educativos, cursos via Internet e outras aplicações computacionais, onde o Laboratório de Multimídia e Processamento Científico poderia servir como base.

Com relação ao ambiente de aprendizagem desenvolvido neste trabalho, além do que foi discutido no item anterior, seria interessante complementá-lo, através da inserção de novos recursos e mídias, bem como a preparação de novos módulos que cubram outros assuntos relacionados ao Planejamento e Controle da Produção. 


\section{REFERÊNCIAS BIBLIOGRÁFICAS}

AFONSO, A.; DIAS, P.; MAIA, J. (1998). O estudo da imagem nos ensinos básico e secundário: o azulejo em Portugal - aplicação pedagógica multimídia. In: SIMPÓSIO DE INVESTIGAÇÃO E DESENVOLVIMENTO DE SOFTWARE EDUCATIVO, 3., Universidade de Évora, Portugal.

http://www.minerva.uevora.pt/simposio/ comunicacoes/Maia/comunic.html $(22 / 02 / 99)$

A INTERNET É A REVOLUÇÃO DO SÉCULO (2000). Folha de São Paulo, São Paulo, 10 jan. Caderno Mundo, p.8.

AKAMATSU, J.I.; SENNA, G.J.; LEITE, A.S. (1997). Aplicação de novas tecnologias de ensino: desenvolvimento de módulos didáticos utilizando ferramentas multimídia. In: CONGRESSO BRASILEIRO DE ENSINO DE ENGENHARIA, 25., Salvador, 1997. Anais. Salvador, ABENGE. v.1, p.139-148.

AZEMI, A. (1997). Developing an active learning environment with courseware approach. In: FRONTIERS IN EDUCATION CONFERENCE, 27., Pittsburgh, Pennsylvania.

http://fairway.ecn.purdue.edu/ fie/fie97/sessions/S1D.htm (08/03/99) 
BADGETT, T.; SANDLER, C. (1994). Criando multimídia em seu PC. São Paulo, Makron Books.

BASTIEN, J.; PIERRE, C.S.; CANTIN, J.F (1997). Multi-media learning tool for teaching mathematics. In: FRONTIERS IN EDUCATION CONFERENCE, 27., Pittsburgh, Pennsylvania.

http://fairway.ecn.purdue.edu/ fie/fie97/sessions/S2D.htm (08/03/99)

BELHOT, R.V. (1993). Uma discussão sobre o problema da abordagem metodológica no ensino da matéria Planejamento e Controle da Produção. In: ENCONTRO NACIONAL DE ENGENHARIA DE PRODUÇÃO, 13., Florianópolis, 1993. Anais. Florianópolis, ABEPRO. p.673-677.

BELHOT, R.V. (1997a). Reflexões e propostas sobre o "ensinar engenharia" para o século XXI. São Carlos. 113p. Tese (Livre-docência) - Escola de Engenharia de São Carlos, Universidade de São Paulo.

BELHOT, R.V. (1997b). Experiências com o ensino apoiado por computador. In: CONGRESSO BRASILEIRO DE ENSINO DE ENGENHARIA, 25., Salvador, 1997. Anais. Salvador, ABENGE. v.1, p.127-138.

BELMONTE, M.V.; BERBEL, J.; CONEJO, R. (1997). TEA: an agrarian economics instructor system. European Journal of Engineering Education, v.22, n.4, p.389399.

BIONDI NETO, L.; CHIGANER, L. (1998). O ensino da engenharia na era da telemática - o ensino de engenharia e a sociedade. In: CONGRESSO BRASILEIRO DE ENSINO DE ENGENHARIA, 26., São Paulo, 1998. Anais eletrônicos. São Paulo, ABENGE. v.2, p.647-663. 
BOARETTO Jr., H. (1996). Ensino apoiado por computador aplicado a ferramentas gráficas gerenciais. São Carlos. 159p. Dissertação (Mestrado) - Escola de Engenharia de São Carlos, Universidade de São Paulo.

BORGES, M.N.; VASCONCELOS, F.H. (1997). Novos princípios e conceitos do projeto curricular para cursos de graduação em engenharia. Revista de Ensino de Engenharia, n.17, p.19-26, jun.

BRANDÃO, E.J.R. (1998). Repensando modelos de avaliação de software educacional. In: SIMPÓSIO DE INVESTIGAÇÃO E DESENVOLVIMENTO DE SOFTWARE EDUCATIVO, 3., Universidade de Évora, Portugal.

http://www.minerva.uevora.pt/simposio/comunicacoes/artigo.html (22/02/99)

CAMPOS, F.; CAMPOS, G.; ROCHA, A.R. (1996). Dez etapas para o desenvolvimento de software educacional do tipo hipermídia. In: CONGRESSO IBERO-AMERICANO DE INFORMÁTICA EDUCATIVA, 3., Barranquilla, Colômbia. http://www.c5.cl/ieinvestiga/ribie96.htm (29/05/00)

CARDOSO, S.H. (1998). Educação médica à distância pela Internet. Informática Médica, v.1, n.5, set/out. http://www.epub.org.br/informaticamedica/n0105/cardoso.htm (24/06/99)

CARLSON, R. (1999). Migrating your course to the online environment. Syllabus Magazine, v.13, n.2, sept.

http://www.syllabus.com/syllabusmagazine/syllmagarc.cfm (08/06/00)

CARNEIRO, M.L. (1997). Como informatizar o ensino de engenharia? In: CONGRESSO BRASILEIRO DE ENSINO DE ENGENHARIA, 25., Salvador, 1997. Anais. Salvador, ABENGE. v.1, p.3-14. 
CARNEIRO, M.L.F.; SCHNACK, W.R. (1999). Videoconferência: ambiente para apoio à educação a distância. In: CONGRESSO BRASILEIRO DE ENSINO DE ENGENHARIA, 27., Natal, 1999. Anais eletrônicos. Natal, ABENGE. p.472-479.

CARVALHO, F.C.A.; TRINDADE, B.; CASTRO, J.E.E. (1999). Ensino à distância na graduação em Engenharia de Produção da UFSC utilizando a Internet como ferramenta. In: CONGRESSO BRASILEIRO DE ENSINO DE ENGENHARIA, 27., Natal, 1999. Anais eletrônicos. Natal, ABENGE. p.2709-2716.

CASAROTTO, R.; KOPITTKE, B.; CASAROTTO F, N. (1998). Tecnologia só não basta. In: CONGRESSO BRASILEIRO DE ENSINO DE ENGENHARIA, 26., São Paulo, 1998. Anais eletrônicos. São Paulo, ABENGE. v.2, p.841-853.

CASTRO, A.O. (1999). Formação de professores e as novas tecnologias da informação e comunicação: reflexões introdutórias. In: SIMPÓSIO IBÉRICO DE INFORMÁTICA EDUCATIVA, 1., Universidade de Aveiro, Aveiro, Portugal. http://event.ua.pt/1siie99/portugues/comunicacoes_frame.html (29/01/00)

CASTRO, M.A.S. et al. (1997). Infra-estrutura de suporte à editoração de material didático utilizando multimídia. Revista Brasileira de Informática na Educação, n.1, p.61-70, set.

CAZARINI, E.W. (1992). A informática no curso de graduação em Engenharia de Produção Mecânica. São Carlos. 144p. Tese (Doutorado) - Escola de Engenharia de São Carlos, Universidade de São Paulo.

CELINSKI, V.G. (1998). Multimídia na educação. In: CONGRESSO BRASILEIRO DE ENSINO DE ENGENHARIA, 26., São Paulo, 1998. Anais eletrônicos. São Paulo, ABENGE. v.2, p.1915-1927. 
CHIGANER, L.; BIONDI NETO, L. (1999). Educação à distância, o paradigma do terceiro milênio. In: CONGRESSO BRASILEIRO DE ENSINO DE ENGENHARIA, 27., Natal, 1999. Anais eletrônicos. Natal, ABENGE. p.1815-1821.

CHUA, C.K. et al. (1997). A multimedia approach to teaching rapid prototyping systems. The International Journal of Engineering Education, v.13, n.2, p.108-116.

CONKLIN, J. (1987). Hypertext: an introduction and survey. IEEE Computer, v.20, n.9, p.17-41, sept.

CORREIA, A.M.A.; VELASCO, A.D. (1998). Ensino de engenharia e tecnologia educacional. In: ENCONTRO DE ENSINO DE ENGENHARIA, 4., Itaipava Petrópolis, RJ, 1998. Anais. p.144-152.

http://acd.ufrj.br/eventos/enceng/enanais.htm (29/05/00)

COSTA NETO, P.L.O. (1999). A educação à distância e as mídias: a experiência da Fundação Vanzolini. In: CONGRESSO BRASILEIRO DE ENSINO DE ENGENHARIA, 27., Natal, 1999. Anais eletrônicos. Natal, ABENGE. p.457-464.

CUNHA Jr., H.; DOMINGUES, S. (1998). Sistema Tutor para o ensino de sistemas de controle. In: CONGRESSO BRASILEIRO DE ENSINO DE ENGENHARIA, 26., São Paulo, 1998. Anais eletrônicos. São Paulo, ABENGE. v.5, p.2271-2285.

DAUGHERTY, M.; FUNKE, B.L. (1998). University faculty and student perceptions of Web-Based Instruction. Journal of Distance Education, v.13, n.1, p.21-39.

DUCHASTEL, P.C. (1990). Discussion: formal and informal learning with hypermedia. In: JONASSEN, D.H., MANDL, H., eds. Designing hypermedia for learning. Berlin, Springer-Verlag. Cap.8. 
EBERSPÄCHER, H.F.; KAESTNER, C.A.A. (1998). A geração de uma ferramenta de autoria para sistemas tutores inteligentes hipermídia. In: SIMPÓSIO DE INVESTIGAÇÃO E DESENVOLVIMENTO DE SOFTWARE EDUCATIVO, 3., Universidade de Évora, Portugal.

http://www.minerva.uevora.pt/simposio/comunicacoes/Eberspacher/ArtigolTS.html $(22 / 02 / 99)$

FARIAS, J.E. (1997). Uma reflexão sobre os cursos de engenharia face às novas infotecnologias. In: CONGRESSO BRASILEIRO DE ENSINO DE ENGENHARIA, 25., Salvador, 1997. Anais. Salvador, ABENGE. v.1, p.174-187.

FEHR, M. (1996). O ensino virtual da era do conhecimento. In: CONGRESSO BRASILEIRO DE ENSINO DE ENGENHARIA, 24., Manaus, 1996. Anais. Manaus, ABENGE. v.2, p.7-15.

FELDER, R.M.; BRENT, R. (1994). Cooperative learning in technical courses. http://www2.ncsu.edu/unity/lockers/users/f/felder/public/Papers/Coopreport.html $(01 / 06 / 00)$

FERREIRA, M.A.G.V. (1999). O ensino de engenharia, os novos paradigmas de aprendizagem e a Internet. In: CONGRESSO BRASILEIRO DE ENSINO DE ENGENHARIA, 27., Natal, 1999. Anais eletrônicos. Natal, ABENGE. p.2701-2708.

FREIRE, M.E.P. (1998). O Sistema Tutor de um ambiente inteligente para treinamento e ensino. São Carlos. 79p. Dissertação (Mestrado) - Instituto de Ciências Matemáticas de São Carlos, Universidade de São Paulo.

FREITAS, M.C.D. et al. (1999). Modelo de aplicação da Internet para educação continuada na área de gerenciamento. In: CONGRESSO BRASILEIRO DE ENSINO DE ENGENHARIA, 27., Natal, 1999. Anais eletrônicos. Natal, ABENGE. p.465-471. 
GARCIA, P.S. (1997). Redes eletrônicas no ensino de ciências: avaliação pedagógica do "Projeto Ecologia" em São Caetano do Sul. São Paulo. 255p. Dissertação (Mestrado) - Universidade Mackenzie.

GILSTER, P. (1995). Como encontrar informações na Internet. São Paulo, Makron Books.

GOMES, S.A.R. (1998). Internet na educação. Uberaba. 63p. Monografia (Curso de Especialização) - Departamento de Informática, Universidade de Ribeirão Preto.

GONÇALVES, C.T.F. (1996). Quem tem medo do ensino a distância. Revista Educação a Distância, n.7/8.

http://www.intelecto.net/ead/consuelo.html (29/05/00)

GRIFFITH, M.L. et al. (1997). Multimedia courseware to enhance the classroom experience. In: FRONTIERS IN EDUCATION CONFERENCE, 27., Pittsburgh, Pennsylvania.

http://fairway.ecn.purdue.edu/ fie/fie97/sessions/S1D.htm (08/03/99)

HANNAFIN, M.J.; PECK, K.L. (1988). The design, development and evaluation of instructional software. New York, Macmillan P.C.

HARB, J.N. et al. (1991). Teaching through the Cycle: application of learning style theory to engineering education at Brigham Young University. Provo, Utah, Brigham Young University Press.

HARB, J.N.; DURRANT, S.O.; TERRY, R.E. (1993). Use of the Kolb Learning Cycle and the 4MAT System in engineering education. Journal of Engineering Education, v.82, n.2, p.70-77, apr. 
HARMS, U.; KRAHN, H.; KURZ, G. (1998). Multimedia learning in the introductory physics course: the Slice units 'Oscilatory Motion'. European Journal of Engineering Education, v.23, n.4, p.503-510.

HINMAN, L.M. (1999). Escaping from Flatland: multimedia authoring. Syllabus Magazine, v.13, n.3, oct.

http://www.syllabus.com/syllabusmagazine/syllmagarc.cfm (08/06/00)

HÖLBIG, C.A. et al. (1998). Ambiente de apoio ao ensino na Internet. In: SIMPÓSIO DE INVESTIGAÇÃO E DESENVOLVIMENTO DE SOFTWARE EDUCATIVO, 3., Universidade de Évora, Portugal.

http://www.minerva.uevora.pt/simposio/ comunicacoes/portugal-infweb.html $(22 / 02 / 99)$

HORVATH, A.O.; TELES, L. (1998). Usando a Web como ferramenta de apoio nas tarefas escolares de pesquisa.

http://www.engenheiro2001.org.br/artigos/Teles3.htm (25/11/99)

JOHNSON, D.W.; JOHNSON, R.T. \& SMITH, K.A. (1998). Active learning: cooperation in the college classroom. 2.ed. Edina, MN, Interaction Press apud FELDER, R.M.; BRENT, R. (1999). How to improve teaching quality.

http://www2.ncsu.edu/unity/lockers/users/f/felder/public/Papers/TQM.htm (01/06/00)

JUCÁ, K. (1997). Pare de gastar e utilize a tecnologia para ganhar produtividade. Informática Exame, ano 12, n.131, p.60-63, fev.

KEHOE, B.P. (1993). Zen e a arte da Internet. Rio de Janeiro, RNP - Rede Nacional de Pesquisa.

KIRKWOOD, A. (1998). New media mania: can information and communication technologies enhance the quality of open and distance learning? Distance Education, v.19, n.2, p.228-241. 
KOLB, D.A. (1984). Experiential Learning: experience as the source of learning and development. Englewood Cliffs, N.J., Prentice-Hall.

KOZAK, D.V. et al. (1998). Uma proposta de metodologia de desenvolvimento de aplicativos para treinamento baseado em computador. In: SIMPÓSIO DE INVESTIGAÇÃO E DESENVOLVIMENTO DE SOFTWARE EDUCATIVO, 3., Universidade de Évora, Portugal.

http://www.minerva.uevora.pt/simposio/comunicacoes/Eberspacher2/ArtigoCBT.html $(24 / 06 / 99)$

KURI, N.P. (1993). Abordagens do processo ensino-aprendizagem: características gerais e metodologias correspondentes. São Carlos, Centro de Tecnologia Educacional Para Engenharia (CETEPE), Escola de Engenharia de São Carlos, Universidade de São Paulo.

KURI, N.P. Ciclo de Aprendizagem: uma estratégia para o planejamento do ensinoaprendizagem. /Trabalho digitado da disciplina SEP-5734 "Sistemas Especialistas Tutores", do Programa de Pós-Graduação em Engenharia de Produção da Escola de Engenharia de São Carlos, Universidade de São Paulo, 1998/

LACERDA, T.; MACHADO, A.B. (1996). Concepção de interfaces para documentos hipermedia. In: SIMPÓSIO DE INVESTIGAÇÃO E DESENVOLVIMENTO DE SOFTWARE EDUCATIVO, 1., Convento dos Capuchos, Costa da Caparica, Portugal.

http://phoenix.sce.fct.unl.pt/simposio/simposio.htm (23/02/99)

LANGLOIS, C. (1998). Universities and new information and communication technologies: issues and strategies. European Journal of Engineering Education, v.23, n.3, p.285-295.

LARGE, A. (1996). Hypertext instructional programs and learner control: a research review. Education for Information, v.14, n.2, p.95-106, june. 
LAUB, L. (1986). What is CD ROM? In: LAMBERT, S., ROPIEQUET, S., eds. CD ROM: the new papyrus. Redmond, Microsoft Press. Section II, Cap. 1, p.47-71.

LEE, T.B. et al. (1994). The World-Wide Web. Communications of the ACM, vol.37, n.8, p.76-82.

LELOUCHE, R. (1998). The successive contributions of computers to education: a survey. European Journal of Engineering Education, v.23, n.3, p.297-308.

LEMAY, L. (1998). Aprenda em 1 semana HTML 4. Rio de Janeiro, Campus.

LENSCHOW, R.J. (1998). From teaching to learning: a paradigm shift in engineering education and lifelong learning. European Journal of Engineering Education, v.23, n.2, p.155-161, june.

LI, H. (1997). Viewpoint: using information technology to enhance engineering education. The International Journal of Engineering Education, v.13, n.5, p.319324.

LIMA, R.V. (1996). A utilização de sistemas multimídia na educação e treinamento: uma aplicação em MRPII. São Carlos. 121p. Dissertação (Mestrado) - Escola de Engenharia de São Carlos, Universidade de São Paulo.

LONGO, H.I. (1997). O engenheiro e o computador. In: CONGRESSO BRASILEIRO DE ENSINO DE ENGENHARIA, 25., Salvador, 1997. Anais. Salvador, ABENGE. v.3, p.1139-1155.

LONGO, H.I. (1999). Aspectos pedagógicos e ideológicos das novas tecnologias aplicadas ao ensino. In: CONGRESSO BRASILEIRO DE ENSINO DE ENGENHARIA, 27., Natal, 1999. Anais eletrônicos. Natal, ABENGE. p.403-409. 
LONGO, W.P.; TELLES, M.H.C. (1998). Programa de desenvolvimento das engenharias: situação atual. Revista de Ensino de Engenharia, n.19, p.74-82, jul.

MAGALHÃES, M.G.M. (1997). Estudo e avaliação de educação à distância utilizando a tecnologia WWW. São Carlos. 154p. Dissertação (Mestrado) - Instituto de Física de São Carlos, Universidade de São Paulo.

MAGALHÃES, M.G.M.; SCHIEL, D. (1997). A method for evaluation of a course delivered via the World Wide Web in Brazil. The American Journal of Distance Education, v.11, n.2, p.64-70.

MARCHETI, A.P.C. ; BELHOT, R.V. (1998). Capacitação profissional para o uso do computador como uma ferramenta pedagógica. In: CONGRESSO BRASILEIRO DE ENSINO DE ENGENHARIA, 26., São Paulo, 1998. Anais eletrônicos. São Paulo, ABENGE. v.1, p.415-423.

MARTINS F', P.D. (1997). Introduzindo novas tecnologias educacionais na formação do engenheiro. In: CONGRESSO BRASILEIRO DE ENSINO DE ENGENHARIA, 25., Salvador, 1997. Anais. Salvador, ABENGE. v.4, p.1912-1924.

MARTINS, R.A. (1999). Aprendizagem ativa e cooperativa: relato de uma experiência. In: CONGRESSO BRASILEIRO DE ENSINO DE ENGENHARIA, 27., Natal, 1999. Anais eletrônicos. Natal, ABENGE. p.1108-1114.

MASUERO, J.R.; GONZÁLEZ, L.A.S. (1998). Ensino de Resistência dos Materiais através da multimídia. In: CONGRESSO BRASILEIRO DE ENSINO DE ENGENHARIA, 26., São Paulo, 1998. Anais eletrônicos. São Paulo, ABENGE. v.6, p.2855-2865.

McCARTHY, B. (1987). The 4MAT System: teaching to learning styles with right/left mode techniques. Barrington, IL, EXCEL, Inc. 
MEDEIROS Fo, D.A.; CINTRA, J.P. (1999a). Avaliação do uso de computadores no ensino e aprendizagem de engenharia. In: CONGRESSO BRASILEIRO DE ENSINO DE ENGENHARIA, 27., Natal, 1999. Anais eletrônicos. Natal, ABENGE. p.411-418.

MEDEIROS F', D.A.; CINTRA, J.P. (1999b). A produção de software para o ensino e aprendizagem de engenharia. In: CONGRESSO BRASILEIRO DE ENSINO DE ENGENHARIA, 27., Natal, 1999. Anais eletrônicos. Natal, ABENGE. p.425-431.

MONSERRAT $\mathrm{F}^{\circ}$, J. (1995). Mudar os cursos de engenharia. Revista Ciência Hoje, v.19, n.112, p.51-53, ago.

MONTGOMERY, S.M. (1995). Addressing diverse learning styles through the use of multimedia. In: FRONTIERS IN EDUCATION CONFERENCE, 25., Atlanta, Georgia. http://fairway.ecn.purdue.edu/v1/asee/fie95/3a2/3a22/3a22.htm (23/02/99)

MORAES, M.; RODRIGUES, R.S.; BARCIA, R.M. (1999). Serviços de suporte ao aluno a distância: primeiros passos para a definição de um modelo próprio. In: CONGRESSO BRASILEIRO DE ENSINO DE ENGENHARIA, 27., Natal, 1999. Anais eletrônicos. Natal, ABENGE. p.1375-1381.

MORAN, J.M. (1994). Novos caminhos no ensino a distância. Informe CEAD, ano 1, n.5, p.1-3, out/nov/dez.

http://www.eca.usp.br/teste/prof/moran/distanci.htm (15/12/99)

MORAN, J.M. (1995). Novas tecnologias e o reencantamento do mundo. Tecnologia Educacional, v.23, n.126, p.24-26, set./out. http://www.eca.usp.br/teste/prof/moran/novtec.htm (15/12/99)

MORAN, J.M. (1997). Como utilizar a Internet na educação. Ciência da Informação, v.26, n.2, p.146-153, maio/ago. 
NASCIMENTO, J.L.; BASTOS, L.R.M. (1996). Uso de multimídia em aulas práticas. In: CONGRESSO BRASILEIRO DE ENSINO DE ENGENHARIA, 24., Manaus, 1996. Anais. Manaus, ABENGE. v.2, p.423-437.

NIELSEN, J. (1995). Multimedia and hypertext: the Internet and beyond. Boston, Academic Press Professional.

NUNES, I.B. (1994). Noções de educação a distância. Revista Educação a Distância, n.4/5, p.7-25.

http://www.intelecto.net/ead/ivonio1.html (29/05/00)

PALADINI, E.P. (1996). Métodos interativos de ensino: suporte tecnológico adaptativo. In: CONGRESSO BRASILEIRO DE ENSINO DE ENGENHARIA, 24., Manaus, 1996. Anais. Manaus, ABENGE. v.2, p.147-159.

PANQUEVA, A.H.G. (1997). Software educativo multimídia: aspectos críticos no seu ciclo de vida. Revista de Ensino de Engenharia, n.1, p.9-18, set.

PEREIRA, A.C. (1999). A interface lúdica na multimídia aplicada ao ensino de Resistência dos Materiais. /Texto de Qualificação para mestrado em Multimeios Instituto de Artes, UNICAMP/

PIMENTEL, M.G.C. (1989). Sistemas hipertexto: discussões, um projeto e sua implementação. São Carlos. 129p. Dissertação (Mestrado) - Instituto de Ciências Matemáticas de São Carlos, Universidade de São Paulo.

PINHEIRO, P.C.C. (1997). Desenvolvimento de um tutorial hipertexto em HTML. In: CONGRESSO BRASILEIRO DE ENSINO DE ENGENHARIA, 25., Salvador, 1997. Anais. Salvador, ABENGE. v.3, p.1171-1184. 
PINHEIRO, P.C.C.; KOURY, R.N.N.; HUEBNER, R. (1996). Desenvolvimento de um tutorial hipertexto com o WinHelp para o ensino de Mecânica dos Fluidos. In: CONGRESSO BRASILEIRO DE ENSINO DE ENGENHARIA, 24., Manaus, 1996. Anais. Manaus, ABENGE. v.2, p.755-766.

PINHEIRO, P.C.C.; KOURY, R.N.N.; MEDEIROS, E.B. (1997). Internet: uma ferramenta para o ensino de engenharia. In: CONGRESSO BRASILEIRO DE ENSINO DE ENGENHARIA, 25., Salvador, 1997. Anais. Salvador, ABENGE. v.3, p.1156-1170.

PROENÇA, A.; MAIA, J. (1996). Matriz hipermédia para desenvolvimento de material pedagógico. In: SIMPÓSIO DE INVESTIGAÇÃO E DESENVOLVIMENTO DE SOFTWARE EDUCATIVO, 1., Convento dos Capuchos, Costa da Caparica, Portugal.

http://phoenix.sce.fct.unl.pt/simposio/simposio.htm (23/02/99)

RANGEL, R. (1996a). A história da Internet (I). Internet World, v.2, n.14, p.90-93, out.

RANGEL, R. (1996b). A história da Internet (II). Internet World, v.2, n.15, p.74-74, nov.

REGISTRO, E.L. (1999). Integração da Internet ao ensino de Física do curso médio das escolas da rede pública. São Carlos. 91p. Dissertação (Mestrado) - Instituto de Física de São Carlos, Universidade de São Paulo.

REINHARDT, A. (1995). Novas formas de aprender. Byte, v.4, n.3, p.34-51, mar.

REIS, L.B.; GRIMONI, J.A.B.; FADIGAS, E.A.F.A. (1996). Reflexões sobre a aplicação da multimídia ao ensino de engenharia. In: CONGRESSO BRASILEIRO DE ENSINO DE ENGENHARIA, 24., Manaus, 1996. Anais. Manaus, ABENGE. v.2, p.581-596. 
RIBAS, P.A.V. (1996). Um novo paradigma em treinamento. Revista de Ensino de Engenharia, n.16, p.20-32, dez.

RIVAS, T. (1998). As tecnologias colaborativas em ambiente distribuído de aprendizagem como um recurso de formação continuada do engenheiro de produção. São Carlos. 107p. Dissertação (Mestrado) - Escola de Engenharia de São Carlos, Universidade de São Paulo.

ROCHA, A.R.; CAMPOS, G.H.B. (1993). Avaliação da qualidade de software educacional. Em Aberto, ano 12, n.57, p.32-44, jan./mar.

SANTOS, G.H.R. (1997). Sistemas hipermídia para o ensino: estendendo as facilidades para o tutor e o estudante. São Carlos. 63p. Dissertação (Mestrado) Instituto de Ciências Matemáticas de São Carlos, Universidade de São Paulo.

SANTOS, N. (1993). Computadores na educação: discutindo alguns pontos críticos. Em Aberto, ano 12, n.57, p.27-31, jan./mar.

SANTOS, N. (1995). Multimídia na educação: da teoria à prática. Porto Alegre, liRfrgs. (Série JAI 95 - XIV Jornada de Atualização em Informática, Canela, RS)

SANTOS NETO, A.J.; SANTOS, L.M.F. (1998). Homo Sapiens VIdens. In: SIMPÓSIO DE INVESTIGAÇÃO E DESENVOLVIMENTO DE SOFTWARE EDUCATIVO, 3., Universidade de Évora, Portugal.

http://www.minerva.uevora.pt/simposio/comunicacoes/freches/HomoSapiens.html $(22 / 02 / 99)$

SCAPIN, R.H. (1997). Desenvolvimento de uma ferramenta para criação e correção automáticas de provas na World-Wide Web. São Carlos. 109p. Dissertação (Mestrado) - Instituto de Física de São Carlos, Universidade de São Paulo. 
SCHANK, R.C. (1994). Active learning through multimedia. IEEE MultiMedia, v.1, n.1, p.69-78.

SEABRA, C. (1993). O computador na criação de ambientes interativos de aprendizagem. Em Aberto, ano 12, n.57, p.45-50, jan./mar.

SEARS, A.L.; WATKINS, S.E. (1996). A multimedia manual on the World Wide Web for telecommunications equipment. IEEE Transactions on Education, v.39, n.3, p.342-348, aug.

SENA, G.J. et al. (1999). Desenvolvimento de um software multimídia para o ensino de tópicos de eletrônica básica. In: CONGRESSO BRASILEIRO DE ENSINO DE ENGENHARIA, 27., Natal, 1999. Anais eletrônicos. Natal, ABENGE. p.318-325.

SHERRY, L. (1995). Issues in distance learning. International Journal of Educational Telecommunications, v.1, n.4, p.337-365.

http://www.cudenver.edu/ Isherry/pubs/issues.html (15/06/99)

SHNEIDERMAN, B. (1989). Reflections on authoring, editing and managing hypertext. In: BARRET, E., ed. The society of text. Cambridge, MA, MIT Press, p.115-131 apud NIELSEN, J. (1995). Multimedia and hypertext: the Internet and beyond. Boston, Academic Press Professional.

SILVEIRA, B.I. (1998). O ensino on-line. In: CONGRESSO BRASILEIRO DE ENSINO DE ENGENHARIA, 26., São Paulo, 1998. Anais eletrônicos. São Paulo, ABENGE. v.6, p.2889-2900.

SILVEIRA, M.A.; MEIRELLES, L.A.; SILVA, M.I.P. (1995). Comentários sobre o curso de engenharia. In: CONGRESSO BRASILEIRO DE ENSINO DE ENGENHARIA, 23., Recife, 1995. Anais. Recife, ABENGE. v.2, p.931-940. 
SILVEIRA, M.R.; ARRUDA, L.V. (1998). Desenvolvimento de um sistema multimídia para autoria e apresentação de cursos de controle. In: SIMPÓSIO DE INVESTIGAÇÃO E DESENVOLVIMENTO DE SOFTWARE EDUCATIVO, 3., Universidade de Évora, Portugal.

http://www.minerva.uevora.pt/simposio/comunicacoes/Silveira/Artigo-SIDSE98.html $(22 / 02 / 99)$

SISCOUTTO, R.A. (1997). Sistema de videoconferência em redes de computadores. São Carlos. 121p. Dissertação (Mestrado) - Instituto de Ciências Matemáticas de São Carlos, Universidade de São Paulo.

SMITH, K.A.; WALLER, A.A. (1997). New paradigms for engineering education. In: FRONTIERS IN EDUCATION CONFERENCE, 27., Pittsburgh, Pennsylvania. http://fairway.ecn.purdue.edu/ fie/fie97/sessions/S3F.htm (08/03/99)

SMYSER, B.M. (1995). Active and cooperative learning. http://www.wpi.edu/ isg_501/bridget.html (07/02/00)

SOARES, E.P.; MENDONÇA, A.A.; ARAÚJO, L.F.F. (1999). Reflexo da velocidade tecnológica no ensino da engenharia. In: CONGRESSO BRASILEIRO DE ENSINO DE ENGENHARIA, 27., Natal, 1999. Anais eletrônicos. Natal, ABENGE. p.69-73.

SOUZA, P.C.; WAZLAWICK, R.S.; HOFFMANN, A.B. (1997). Um ambiente construtivista em realidade virtual para aprendizagem em Engenharia Civil. Revista de Ensino de Engenharia, n.18, p.24-30, nov.

STEFFEN Jr., V. (1997). A atual situação do ensino de engenharia no Brasil e perspectivas para o futuro. Revista de Ensino de Engenharia, n.18, p.36-39, nov.

STICE, J.E. (1987). Using Kolb's Learning Cycle to improve student learning. Engineering Education, v.77, n.5, p.291-296, feb. 
SUN, C.T.; CHOU, C. (1996). Experiencing CORAL: design and implementation of distant cooperative learning. IEEE Transactions on Education, v.39, n.3, p.357-366, aug.

THORPE, M. (1998). Assessment and 'third generation' distance education. Distance Education, v.19, n.2, p.265-286.

TODOROV, J.C. (1994). A importância da educação a distância. Revista Educação a Distância, n.4/5.

http://www.ibase.org.br/edist/dist/ (08/06/00)

UM GURU EM CADA MESA DE TRABALHO (1994). Informática Exame, ano 9, n.101, ago.

UNIVERSIDADE FEDERAL DE MINAS GERAIS. Escola de Engenharia (1995). Programa de modernização do ensino da EE-UFMG apud SALUM, M.J.G.; GUIMARÃES, H.A. (1996). A diversificação na formação do engenheiro - uma realidade ou necessidade? In: CONGRESSO BRASILEIRO DE ENSINO DE ENGENHARIA, 24., Manaus, 1996. Anais. Manaus, ABENGE. v.2, p.121-130.

VALENTE, J.A. (1993). Computadores e conhecimento: repensando a educação. Campinas, Gráfica Central da UNICAMP.

VALENTE, J.A.; ALMEIDA, F.J. (1997). Visão analítica da informática na educação no Brasil: a questão da formação do professor. Revista Brasileira de Informática na Educação, n.1, p.45-60, set.

VIALI, L. (1999). SHEE - Sistema Hipermídia de Ensino de Estatística. In: CONGRESSO BRASILEIRO DE ENSINO DE ENGENHARIA, 27., Natal, 1999. Anais eletrônicos. Natal, ABENGE. p.280-288. 
VILLAS, M.V.; CAMPOS, R.D. (1984). A Internet no Brasil: histórico, descrição e orientação para utilização. In: LAQUEY, T., RYER, J.C., eds. O manual da Internet: um guia introdutório para acesso às redes globais. Rio de Janeiro, Campus. Apêndice B, p.251-262. 